\title{
DOCUMENTATION OF REVISIONS TO THE REGIONAL AQUIFER SYSTEM ANALYSIS MODEL OF THE NEW JERSEY COASTAL PLAIN
}

Water-Resources Investigations Report 03-4268

In cooperation with the

NEW JERSEY DEPARTMENT OF ENVIRONMENTAL PROTECTION

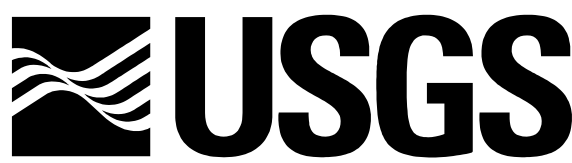




\section{DOCUMENTATION OF REVISIONS TO THE REGIONAL AQUIFER SYSTEM ANALYSIS MODEL OF THE NEW JERSEY COASTAL PLAIN}

By Lois M. Voronin

U.S. Geological Survey

Water-Resources Investigations Report 03-4268

In cooperation with the

NEW JERSEY DEPARTMENT OF ENVIRONMENTAL PROTECTION 


\section{U.S. DEPARTMENT OF THE INTERIOR \\ GALE A. NORTON, Secretary}

\section{U.S. GEOLOGICAL SURVEY}

Charles G. Groat, Director

For additional information write to:

District Chief

U.S. Geological Survey

Mountain View Office Park

810 Bear Tavern Road

West Trenton, NJ 08628
Copies of this report can be purchased from:

U.S. Geological Survey Branch of Information Services Box 25286

Denver, CO 80225-0286 


\section{Contents}

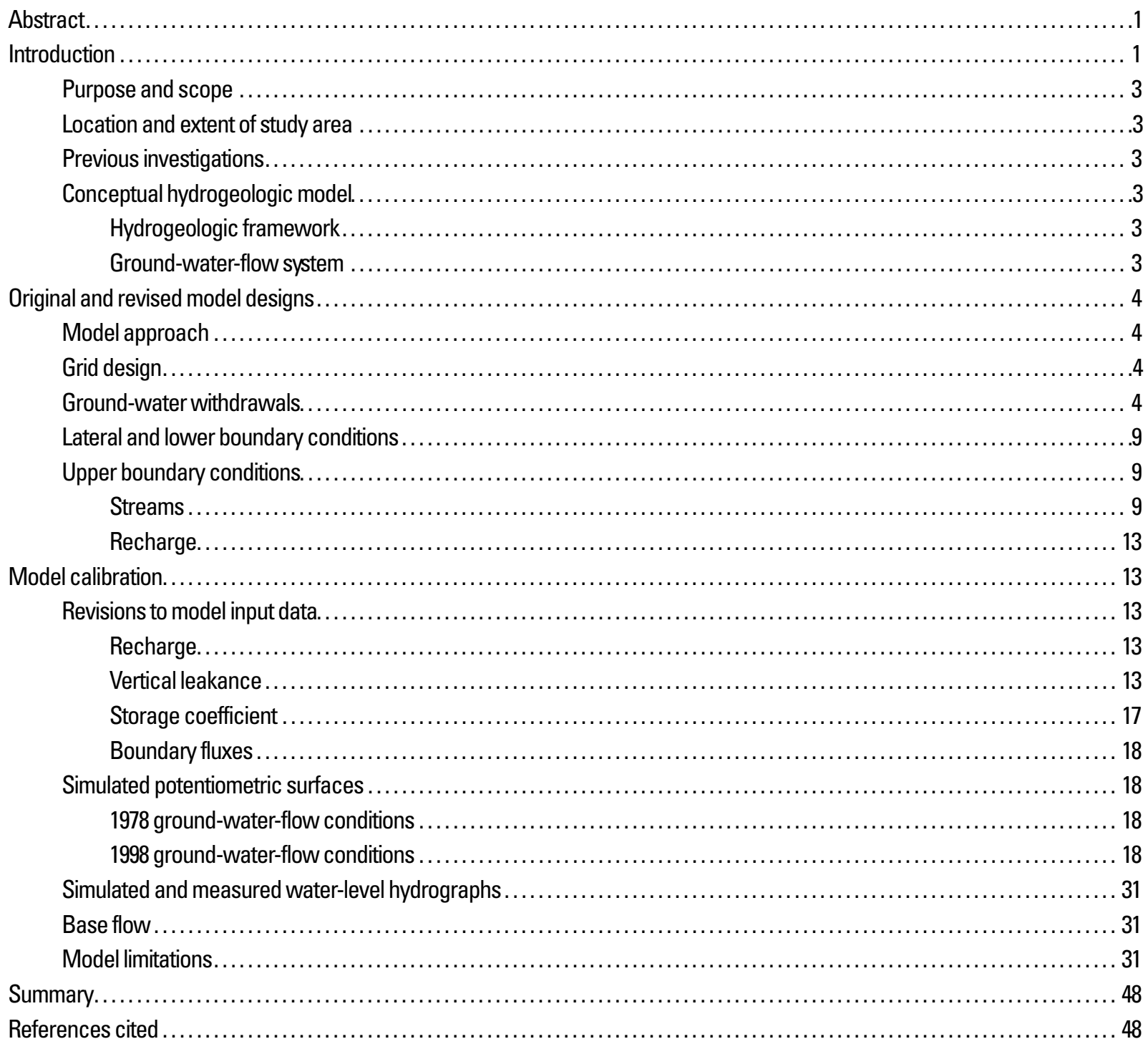

\section{Plate}

[In pocket]

1. Map showing finite-difference grid and generalized lateral boundaries of the original and revised Regional Aquifer System Analysis models

\section{CD-ROM}

[In pocket]

1. Read me file and model files. 


\section{Figures}

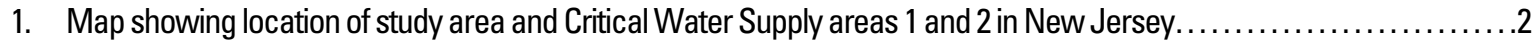

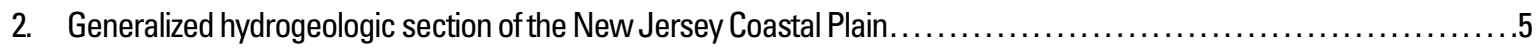

3. Schematic representation of aquifers, confining units, and boundary conditions used in the revised

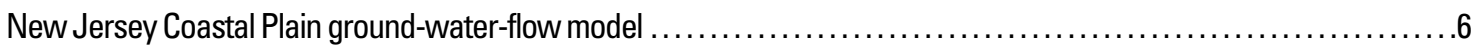

4. Graph showing average and total annual ground-water withdrawals for each stress period for the

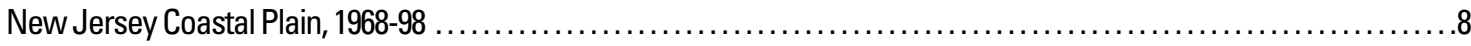

5. Map showing model cells that represent stream reaches in the study area, New Jersey Coastal Plain............. 12

6-8. Maps showing:

6. Recharge rates used in the model and the location of selected drainage basins and streamflow-gaging stations in the model area, New Jersey Coastal Plain ............................. 14

7. Location of, and references for, studies that reported ground-water recharge rates

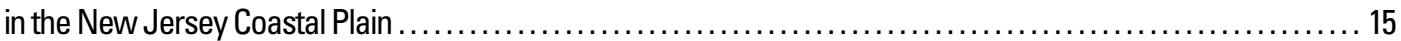

8. Vertical leakance used in the model for the Navesink-Hornerstown confining unit and location of selected wells in the study area, New Jersey Coastal Plain

9. Hydrographs of measured and simulated water levels in well 25-486 screened in the Wenonah-Mount Laurel aquifer that result from two model scenarios with storage coefficients of 0.001 and 0.0001 , New Jersey Coastal Plain, 1985-98.

\section{0 - 22. Maps showing:}

10. Location of ground-water withdrawal wells screened in the Lower Potomac-Raritan-Magothy aquifer in Delaware, 1997.

11. Simulated and interpreted potentiometric surfaces of the (a) Wenonah-Mount Laurel aquifer and (b) Englishtown aquifer system, New Jersey Coastal Plain, 1978

12. Simulated water table of the Holly Beach water-bearing zone, New Jersey Coastal Plain, 1998.

13. Simulated water table and simulated potentiometric surfaces of the upper Kirkwood-

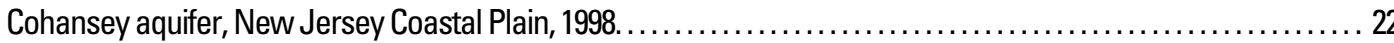

14. Simulated and interpreted potentiometric surfaces of the lower Kirkwood Cohansey aquifer system and confined Kirkwood aquifer, New Jersey Coastal Plain, 1998.

15. Simulated and interpreted potentiometric surfaces of the Piney Point aquifer, New Jersey Coastal Plain, 1998.

16. Simulated and interpreted potentiometric surfaces of the Vincentown aquifer,

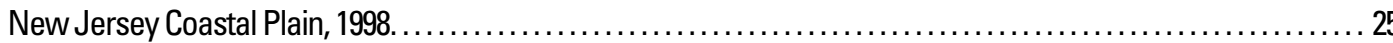

17. Simulated and interpreted potentiometric surfaces of the Wenonah-Mount Laurel aquifer, New Jersey Coastal Plain, 1998

18. Simulated and interpreted potentiometric surfaces of the Englishtown aquifer system, New Jersey Coastal Plain, 1998.

19. Simulated and interpreted potentiometric surfaces of the Upper Potomac-Raritan-

Magothy aquifer, New Jersey Coastal Plain, 1998.

20. Simulated and interpreted potentiometric surfaces of the Middle Potomac-RaritanMagothy aquifer, New Jersey Coastal Plain, 1998.

21. Simulated and interpreted potentiometric surfaces of the Lower Potomac-RaritanMagothy aquifer, New Jersey Coastal Plain, 1998.

22. Location of selected observation wells for which hydrographs of simulated and measured water levels have been plotted, New Jersey Coastal Plain . 


\section{Figures - Continued}

23-49. Hydrographs of simulated and measured water levels in observation well:

23. Well 29-141 screened in the Kirkwood-Cohansey aquifer system, New Jersey

Coastal Plain, 1978-98.

24. Well 1-578 screened in the confined Kirkwood aquifer, New Jersey Coastal Plain, 1978-98. .................. 33

25. Well 1-37 screened in the confined Kirkwood aquifer, New Jersey Coastal Plain, 1973-98 .................. 34

26. Well 1-834 screened in the Piney Point aquifer, New Jersey Coastal Plain, 1988-98...................... 34

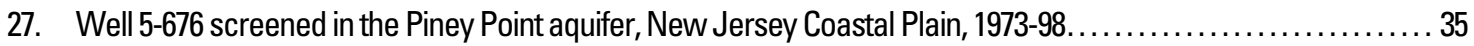

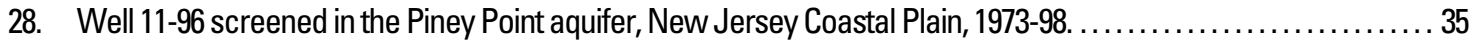

29. Well 29-139 screened in the Vincentown aquifer, New Jersey Coastal Plain, 1978-98. ................... 36

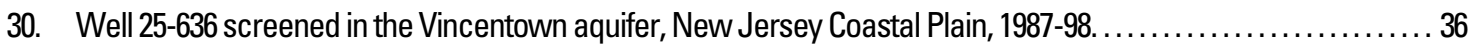

31. Well 25-353 screened in the Wenonah-Mount Laurel aquifer, New Jersey Coastal Plain, 1984-97 ............. 37

32. Well 7-478 screened in the Wenonah-Mount Laurel aquifer, New Jersey Coastal Plain, 1973-98. . . . . . . . . . . 38

33. Well 25-637 screened in the Wenonah-Mount Laurel aquifer, New Jersey Coastal Plain, 1987-98............. 38

34. Well 29-140 screened in the Wenonah-Mount Laurel aquifer system, New Jersey Coastal Plain, 1978-98. ....... 39

35. Well 29-138 screened in the Englishtown aquifer system, New Jersey Coastal Plain, $1973-98 \ldots \ldots \ldots \ldots \ldots \ldots . \ldots . \ldots . \ldots$

36. Well 25-429 screened in the Englishtown aquifer system, New Jersey Coastal Plain, 1978-98. . . . . . . . . . . 40

37. Well 25-638 screened in the Englishtown aquifer system, New Jersey Coastal Plain, 1987-98. .............. 40

38. Well 5-259 screened in the Englishtown aquifer system, New Jersey Coastal Plain, 1973-98. ................ 41

39. Well 5-258 screened in the Upper Potomac-Raritan-Magothy aquifer, New Jersey Coastal Plain, 1973-98. . . . . 41

40. Well 7-477 screened in the Upper Potomac-Raritan-Magothy aquifer, New Jersey Coastal Plain, 1973-98 ...... 42

41. Well 15-728 screened in the Upper Potomac-Raritan-Magothy aquifer, New Jersey Coastal Plain, 1987-98 _.... 42

42. Well 25-639 screened in the Upper Potomac-Raritan-Magothy aquifer, New Jersey Coastal Plain, 1987-98. . . . . 43

43. Well 5-261 screened in the Middle Potomac-Raritan-Magothy aquifer, New Jersey Coastal Plain, 1973-98. ..... 43

44. Well 15-713 screened in the Middle Potomac-Raritan-Magothy aquifer, New Jersey Coastal Plain, 1987-1998 . . 44

45. Well 33-251 screened in the Middle Potomac-Raritan-Magothy aquifer, New Jersey Coastal Plain, 1978-98 . . . . 44

46. Well 7-283 screened in the Lower Potomac-Raritan-Magothy aquifer, New Jersey Coastal Plain, 1973-98. . . . . 45

47. Well 33-187 screened in the Lower Potomac-Raritan-Magothy aquifer, New Jersey Coastal Plain, 1973-98. . . . . 45

48. Well 15-712 screened in the Lower Potomac-Raritan-Magothy aquifer, New Jersey Coastal Plain, 1987-98. . . . . 46

49. Well 5-262 screened in the Lower Potomac-Raritan-Magothy aquifer, New Jersey Coastal Plain, 1973-98....... 46

\section{Tables}

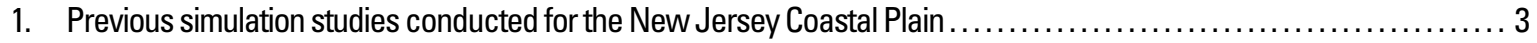

2. Geologic and hydrologic units of the New Jersey Coastal Plain and model units used in the

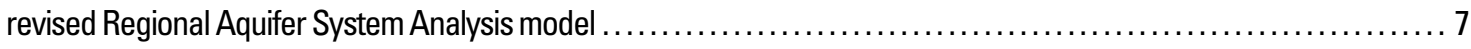

3. Average daily ground-water withdrawals from each aquifer and lateral boundary flows by

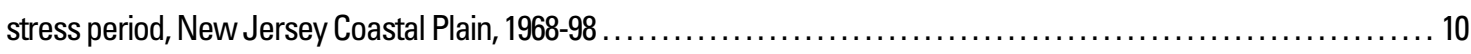

4. Simulated and estimated base flows at five continuous-record streamflow-gaging stations in the New Jersey Coastal Plain 


\section{Conversion Factors and Datum}

\begin{tabular}{|c|c|c|}
\hline Multiply & By & To obtain \\
\hline \multicolumn{3}{|c|}{ Length } \\
\hline inch (in.) & 2.54 & centimeter $(\mathrm{cm})$ \\
\hline inch (in.) & 25.4 & millimeter $(\mathrm{mm})$ \\
\hline foot $(\mathrm{ft})$ & 0.3048 & meter $(\mathrm{m})$ \\
\hline mile (mi) & 1.609 & kilometer (km) \\
\hline \multicolumn{3}{|c|}{ Area } \\
\hline square mile $\left(\mathrm{mi}^{2}\right)$ & 2.590 & square kilometer $\left(\mathrm{km}^{2}\right)$ \\
\hline \multicolumn{3}{|c|}{ Volume } \\
\hline gallon (gal) & 3.785 & $\operatorname{liter}(\mathrm{L})$ \\
\hline gallon (gal) & 0.003785 & cubic meter $\left(\mathrm{m}^{3}\right)$ \\
\hline million gallons (Mgal) & & cubic meter $\left(\mathrm{m}^{3}\right)$ \\
\hline \multicolumn{3}{|c|}{ Flow rate } \\
\hline cubic foot per second $\left(\mathrm{ft}^{3} / \mathrm{s}\right)$ & 0.02832 & cubic meter per second $\left(\mathrm{m}^{3} / \mathrm{s}\right)$ \\
\hline gallon per minute (gal/min) & 0.06309 & liter per second $(\mathrm{L} / \mathrm{s})$ \\
\hline gallon per day (gal/d) & 0.003785 & cubic meter per day $\left(\mathrm{m}^{3} / \mathrm{d}\right)$ \\
\hline million gallons per day (Mgal/d) & 0.04381 & cubic meter per second $\left(\mathrm{m}^{3} / \mathrm{s}\right)$ \\
\hline \multicolumn{3}{|c|}{ Hydraulic conductivity } \\
\hline${ }^{1}$ foot per day $(\mathrm{ft} / \mathrm{d})$ & 0.3048 & meter per day $(\mathrm{m} / \mathrm{d})$ \\
\hline \multicolumn{3}{|c|}{ Transmissivity } \\
\hline${ }^{2}$ foot squared per day $\left(\mathrm{ft}^{2} / \mathrm{d}\right)$ & 0.09290 & meter squared per day $\left(\mathrm{m}^{2} / \mathrm{d}\right)$ \\
\hline \multicolumn{3}{|c|}{$\begin{array}{l}\text { Vertical coordinate information is referenced to the National Geodetic Vertical Datum of } 1929 \\
\text { (NGVD of 29). }\end{array}$} \\
\hline
\end{tabular}

\footnotetext{
${ }^{1}$ The standard unit for hydraulic conductivity is cubic foot per day per square foot of aquifer cross-sectional area, or $\left(\mathrm{ft}^{3} / \mathrm{d}\right) / \mathrm{ft}^{2}$. In this report, this expression is reduced to its simplest form, foot per day ( $\left.\mathrm{ft} / \mathrm{d}\right)$.

${ }^{2}$ The standard unit for transmissivity is cubic foot per day per square foot times feet of aquifer thickness, or $\left.\left[\mathrm{ft}^{3} / \mathrm{d}\right) / \mathrm{ft}^{2}\right] \mathrm{ft}$. In this report, this expression is reduced to its simplest form, square foot per day $\left(\mathrm{ft}^{2} / \mathrm{d}\right)$.
} 


\title{
Documentation of Revisions to the Regional Aquifer System Analysis Model of the New Jersey Coastal Plain
}

\author{
By Lois M. Voronin
}

\section{Abstract}

The model, which simulates flow in the New Jersey Coastal Plain sediments, developed for the U. S. Geological Survey Regional Aquifer System Analysis (RASA) program was revised. The RASA model was revised with (1) a rediscretization of the model parameters with a finer cell size, (2) a spatially variable recharge rate that is based on rates determined by recent studies and, (3) ground-water withdrawal data from 1981 to 1998.

The RASA model framework, which subdivided the Coastal Plain sediments into 10 aquifers and 9 confining units, was preserved in the revised model. A transient model that simulates flow conditions from January 1, 1968, to December 31, 1998, was constructed using 21 stress periods.

The model was calibrated by attempting to match the simulated results with (1) estimated base flow for five river basins, (2) measured water levels in long-term hydrographs for 28 selected observation wells, and (3) potentiometric surfaces in the model area for 1978, 1983, 1988, 1993, and 1998 conditions. The estimated and simulated base flow in the five river basins compare well. In general, the simulated water levels matched the interpreted potentiometric surfaces and the measured water levels of the hydrographs within 25 feet.

\section{Introduction}

As part of an ongoing program to maintain ground-waterflow models constructed in New Jersey, the U.S. Geological Survey (USGS), in cooperation with New Jersey Department of Environmental Protection (NJDEP), developed a standardized procedure to archive the models and revise selected models by incorporating recent data, such as withdrawal data and simulation techniques. The Regional Aquifer System Analysis finitedifference numerical model of flow in the New Jersey Coastal Plain sediments (Martin, 1998) was revised by (1) rediscretizing the model parameters with a finer cell size, (2) using a spatially variable recharge rate that is based on rates determined in studies conducted since the model was initially developed in
1981 and, (3) using recent ground-water withdrawal data for 1981-98.

The New Jersey Coastal Plain flow model was constructed in 1978 for the U.S Geological Survey Regional Aquifer System Analysis (RASA) program (Martin, 1998). The objective of the RASA program was to appraise the major ground-water systems in the United States. For the RASA program in New Jersey, a regional model of flow in 10 aquifers and through 9 intervening confining units that compose the New Jersey Coastal Plain sediments was developed. Because of the large model area, $9,000 \mathrm{mi}^{2}$, and the limited computer capabilities, the model was designed with a coarse grid. Cell size ranged from $6.25 \mathrm{mi}^{2}$ in the southeastern Coastal Plain to $47.5 \mathrm{mi}^{2}$ in offshore areas.

The goals of the RASA program were met with the original model design; however, the current water-management needs in New Jersey require a more detailed model that incorporates recent simulation techniques and the most recent (1998) ground-water withdrawal data. Instead of constructing a new model of the New Jersey Coastal Plain sediments, the RASA model was updated.

In 1986 in response to rapidly declining water levels in the New Jersey Coastal Plain, the NJDEP designated Critical Water-Supply Areas 1 and 2 (fig. 1). Critical Area 1 is located in parts of Middlesex, Monmouth, and Ocean Counties. Withdrawals from the Wenonah-Mount Laurel aquifer, Englishtown aquifer system, and the Upper and Middle Potomac-RaritanMagothy aquifers within Critical Area 1 were restricted beginning in 1989. Critical Area 2 is located in Camden and parts of Atlantic, Burlington, Cumberland, Gloucester, Monmouth, Ocean, and Salem Counties. Ground-water withdrawals from the Upper, Middle, and Lower Potomac-Raritan-Magothy aquifers in Critical Area 2 were restricted beginning in 1996. As a result of the reduced ground-water withdrawals in these areas, water levels have risen as much as $110 \mathrm{ft}$ from 1988 to 1998(Lacombe and Rosman, 2001). The updated RASA model can be used to evaluate the regional effect of reduced groundwater withdrawals on water levels and as a tool to re-evaluate water-management strategies in these areas. 


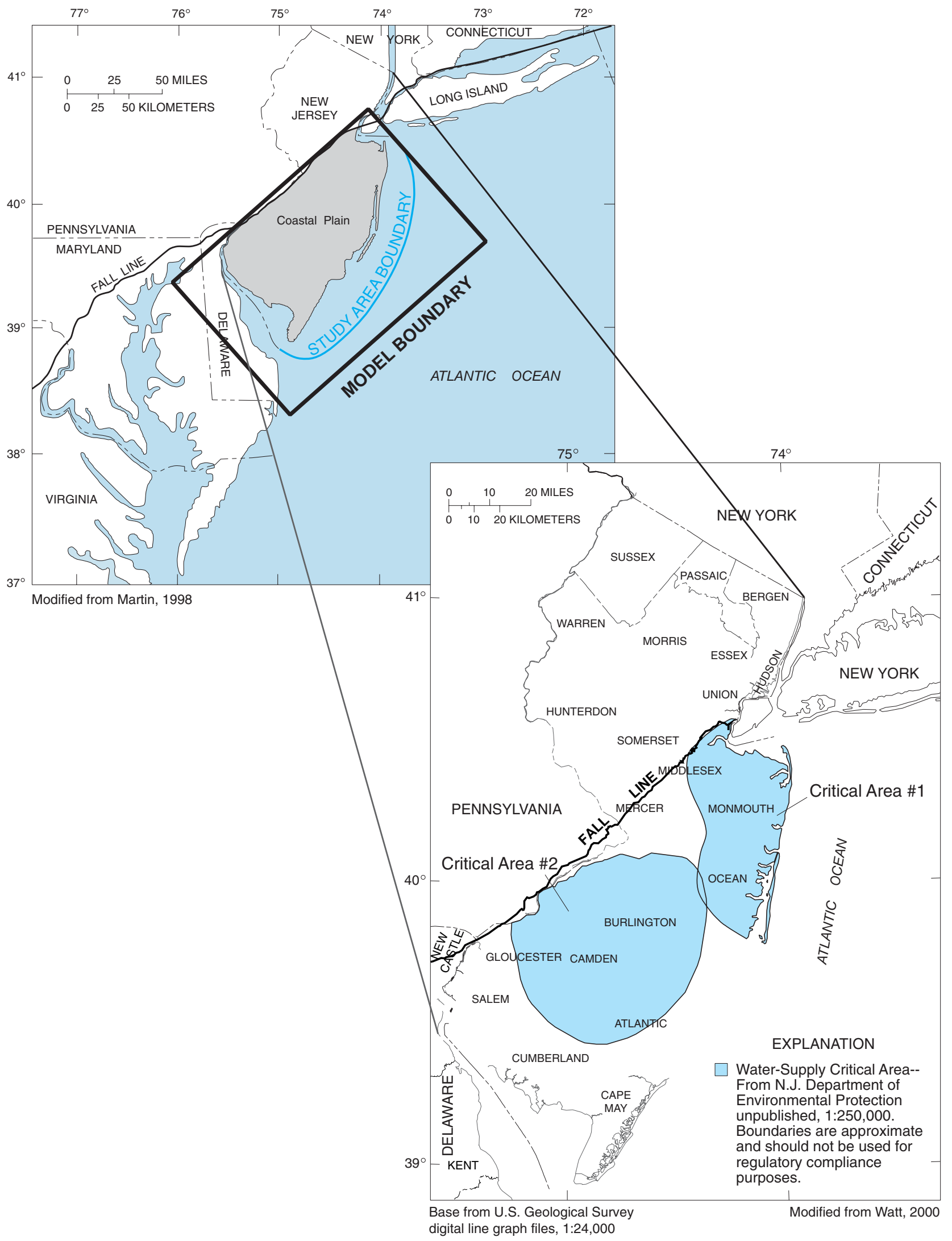

Figure 1. Location of study area and Critical Water Supply areas 1 and 2 in New Jersey. 
The revised RASA model also can be used to evaluate the regional effect on water levels of a proposed increase in groundwater withdrawals of 2,017 Mgal/d in Salem and Gloucester Counties. This area is adjacent to an area that has experienced water-level declines of more than $100 \mathrm{ft}$ since pumping began in the early 1900's. Results of the withdrawal scenarios can be used to evaluate alternative resource-management strategies in these areas.

\section{Purpose and Scope}

The purpose of this report is to document the revisions made to the RASA model (Martin, 1998). The report includes a detailed analysis of the calibration. Values for simulated and estimated base flow in five river basins in the New Jersey Coastal Plain are presented in tables and hydrographs of simulated and measured water levels in 28 observation wells, and simulated and interpreted potentiometric surfaces for 1998 conditions are shown in figures. The model simulates withdrawal conditions from 1968 to 1998.

\section{Location and Extent of Study Area}

The extent of the model area shown in figure 1 is the same as that of the RASA model. The RASA model includes all of the New Jersey Coastal Plain sediments and extends into New Castle County, Delaware and Philadelphia and Bucks Counties, Pennsylvania. For this study, revisions were made only to an area within the New Jersey Coastal Plain sediments, which is indicated by the shading on the inset map shown in figure 1 . The study area is smaller than the model area, includes all of New Jersey, and extends offshore about $20 \mathrm{mi}$ in the southeast.

\section{Previous Investigations}

The two previous studies where simulation techniques were used to investigate the regional ground-water flow system of the New Jersey Coastal Plain are listed in table 1 along with the year of the most recent water-level data and the minimum cell size. Studies conducted prior to 1980 were limited in extent and focused on ground-water flow in one aquifer; these studies are not cited in this report. Martin (1998) developed the first regional ground-water-flow model that included all the aquifers of the New Jersey Coastal Plain (RASA model). Pope and Gordon (1999) expanded on Martin's work and simulated ground- water flow in the New Jersey Coastal Plain aquifers that extend to the Continental Shelf (CP model).

\section{Conceptual Hydrogeologic Model}

The hydrogeology of the New Jersey Coastal Plain is discussed briefly in this section. The New Jersey Coastal Plain sediments are described in detail by Zapecza (1989).

\section{Hydrogeologic Framework}

The New Jersey Coastal Plain sediments consist of alternating layers of gravel, sand, silt, and clay that gently dip and thicken to the southeast and overlie crystalline bedrock (fig. 2). Most aquifers and confining units in the New Jersey Coastal Plain were mapped by Zapecza (1989). Martin (1998) modified the hydrogeologic framework presented in the report by Zapecza for the RASA model and represented the Coastal Plain sediments as 10 major aquifers and 9 intervening confining units.

\section{Ground-Water-Flow System}

The Coastal Plain ground-water-flow system is dynamic (changes with time) and has changed greatly in response to ground-water withdrawals. A brief discussion of the current (1998) ground-water-flow system is given here. For a more detailed discussion of the ground-water-flow system see Martin (1998). Ground-water flow in the New Jersey Coastal Plain sediments under current conditions (1998) is affected by the hydraulic properties of the saturated sediments, topography, and ground-water withdrawals. In general, topographic highs are recharge areas and topographic lows are discharge areas. Ground-water withdrawals in topographic lows can reverse ground-water-flow directions in these areas, which then can become ground-water recharge areas. Discharge areas in the New Jersey Coastal Plain include the Atlantic Ocean, the Delaware River, the Delaware and Raritan Bays, and streams. Examples of recharge areas are the high-altitude areas (250 ft., NGVD of 1929) in northwestern Monmouth County.

In general, aquifers transmit water easily compared to confining units, which transmit water only to a small extent. Flow within confining units is predominantly vertical as a result of large vertical gradients within confining units. Flow within aquifers is horizontal with a small vertical component.

Table 1. Previous simulation studies conducted for the New Jersey Coastal Plain

[RASA, Regional Aquifer System Analysis; CP, Coastal Plain]

\begin{tabular}{clcc}
\hline Model (acronym) & \multicolumn{1}{c}{ Reference } & $\begin{array}{c}\text { Most recent water- } \\
\text { level data used in } \\
\text { study }\end{array}$ & $\begin{array}{c}\text { Minimum cell size } \\
\text { (square miles) }\end{array}$ \\
\hline RASA & Martin (1998) & 1978 & 6.25 \\
CPOP & Pope and Gordon (1999) & 1988 & 6.25
\end{tabular}




\section{Documentation of Revisions to the Regional Aquifer System Analysis Model of the New Jersey Coastal Plain}

Six steep regional cones of depression have developed in the New Jersey Coastal Plain. Two cones are centered in southern Monmouth and northwestern Ocean Counties, three in central Camden County, and one in southeastern Atlantic County (Lacombe and Rosman, 2001, sheets 3, 6, 7, 8, 9, 10). All of these regional cones of depression have developed in response to the decline in water levels that resulted from large groundwater withdrawals that began in the late 1800's.

\section{Original and Revised Model Designs}

The RASA model was compiled on an early computer system for a multi-layer finite-difference ground-water-flow model. The model computer code used to simulate groundwater flow was a modified version (Leahy, 1982) of the computer program developed by Trescott (1975). For this study, the input data were formatted for use with MODFLOW-96, a version of the modular finite-difference ground-water-flow model by Harbaugh and McDonald (1996).

\section{Model Approach}

For the quasi-three dimensional representation of the aquifers and confining units of the New Jersey Coastal Plain, flow is assumed to be entirely horizontal within the aquifers and vertical through the confining units. Water levels within the confining units were not simulated, but vertical flow through the confining units was calculated by using vertical leakance (vertical hydraulic conductivity divided by thickness). The RASA model assignment of the Coastal Plain sediments into aquifers and confining units was not changed in the revised model. The geologic and hydrogeologic units and the corresponding modellayer designations used in the model are listed in table 2. A generalized hydrogeologic section of the New Jersey Coastal Plain and the designated model layers are shown in figure 2. A schematic representation of the model units used to represent the hydrogeologic units (fig. 2) is shown in figure 3. Martin (1998) modeled the 10 major aquifers and the streams using an 11layer model. Martin modeled the streams as a layer. In the revised model, the streams were modeled using the river and drain package of MODFLOW-96. Hence, an 11th layer was not needed in the revised model.

\section{Grid Design}

The RASA grid cell size was $6.25 \mathrm{mi}^{2}$ in the northern and southwestern New Jersey Coastal Plain, $9.375 \mathrm{mi}^{2}$ in the southeastern Coastal Plain, and as much as $47.5 \mathrm{mi}^{2}$ in offshore areas (plate 1). The grid had 29 rows and 51 columns. In the new grid (plate 1) with 135 rows and 245 columns, the cell size is 0.25 $\mathrm{mi}^{2}$ in the northern and southwestern New Jersey Coastal Plain, $0.31 \mathrm{mi}^{2}$ in the southeastern Coastal Plain, and as much as 3.16 $\mathrm{mi}^{2}$ in offshore areas. The ratio of the number of new cells to the original number of cells is 25 to 1 in onshore areas.

Rows 1 and 29 and columns 1 and 51 were not active in the RASA model and are not included as part of the grid area of the revised model. The relation between the RASA and revised model grids is shown in plate 1 .

\section{Ground-Water Withdrawals}

A transient ground-water-flow model that simulates conditions from January 2, 1968, to December 31, 1998, was constructed with 21 stress periods and 10 time steps within each stress period. Ground-water withdrawal data used in the revised model are those reported to the NJDEP by water purveyors. The withdrawal data also are maintained in a USGS computer database. Average annual withdrawals were used for all stress periods (fig. 4). Because stress periods 4 through 21 are 1 year in length, average annual withdrawals are equivalent to total annual withdrawals during these stress periods. Withdrawals for stress periods 1 to 3 are the same as withdrawals for stress periods 7,8 , and 9 of the RASA model. Stress period 1 extended from January 2, 1968, to January 1, 1973; period 2, January 2, 1973, to January 1, 1978; and period 3, January 2, 1978, to January 1,1981 , in the RASA model. Annual ground-water withdrawals for these three stress periods were averaged for these 3to 5 -year time periods. In the revised model, stress periods 2 and 3 have the same time periods as stress periods 8 and 9 in the RASA model; however, stress period 1 in the revised model represents an interval of 100 years.

The use of a time interval of 100 years enabled the model to simulate steady-state flow conditions using average groundwater withdrawals from January 2, 1968, to January 1, 1973. Initial water levels for this period were the water levels calculated from the original model for average conditions during 1968-73. During the sensitivity analysis of the effects of withdrawals on the ground-water-flow system, Martin (1998) found that after 10 years with a constant pumping rate the change in water levels would be less than $1 \mathrm{ft} / \mathrm{yr}$ anywhere in the aquifer system. A period of 100 years was more than enough time to simulate steady-state flow conditions with average from January 2,1968 , to January 1,1973 , ground-water withdrawals. In Martin (1998), water-level changes simulated after only 10 years also were slight, such that the residual effect of changes in withdrawals rates prior to 1968 (if they were simulated) would have little effect on the simulated response during the period of interest, after 1978.

Water levels simulated with the revised model at the end of stress periods 1,2, and 3 are comparable to those at the end of stress period 7, 8, and 9 simulated with the RASA model. Water levels at the end of stress period 2 are comparable to the 1978 water levels that Martin (1998) used for calibration. 


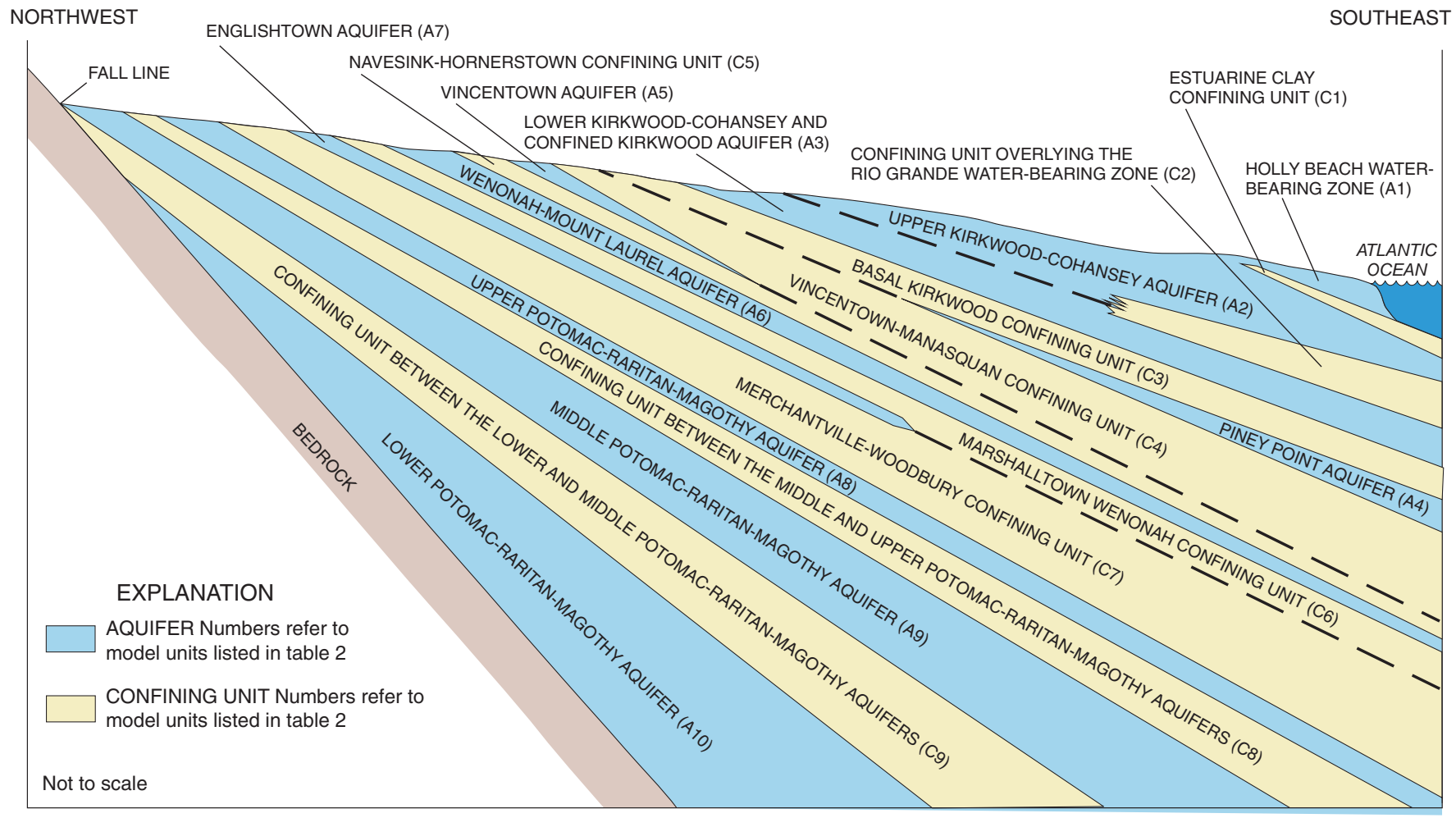

Figure 2. Generalized hydrogeologic section of the New Jersey Coastal Plain. (Modified from Martin, 1998) 


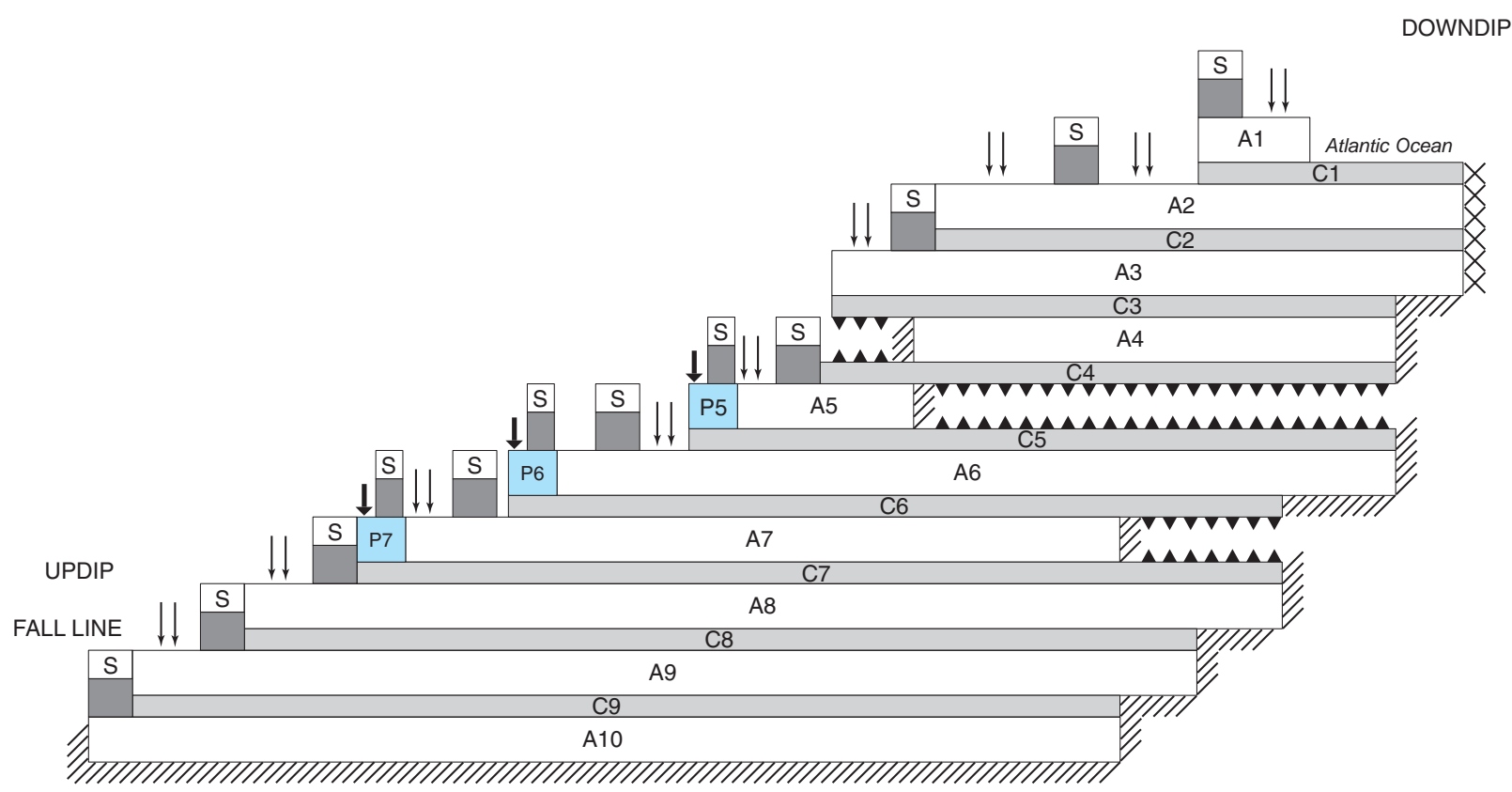

\section{EXPLANATION}

IFER-Number refers to model unit listed in table 2

CONFINING UNIT-Numbers refers to model unit listed in table 2

S SURFACE-WATER STAGE

STREAMBED OR LAKEBED CONDUCTANCE IN OUTCROP AREA

P5

OUTCROP AREA OF CONFINING UNIT SIMULATED AS AN AQUIFER LAYER-Number refers to model layer representing the vertical flux through the confing-unit outcrop area

Figure 3. Schematic representation of aquifers, confining units, and boundary conditions used in the revised New Jersey Coastal Plain ground-water-flow model. (Modified from Martin, 1998, figure 4) 
Table 2. Geologic and hydrogeologic units of the New Jersey Coastal Plain and model units in the revised Regional Aquifer System Analysis model

[Modified from Zapecza (1989, table 2) and Seaber (1965, table 3); shading indicates adjacent geologic or hydrogeologic unit is not defined; letter and number in parentheses is the model layer]

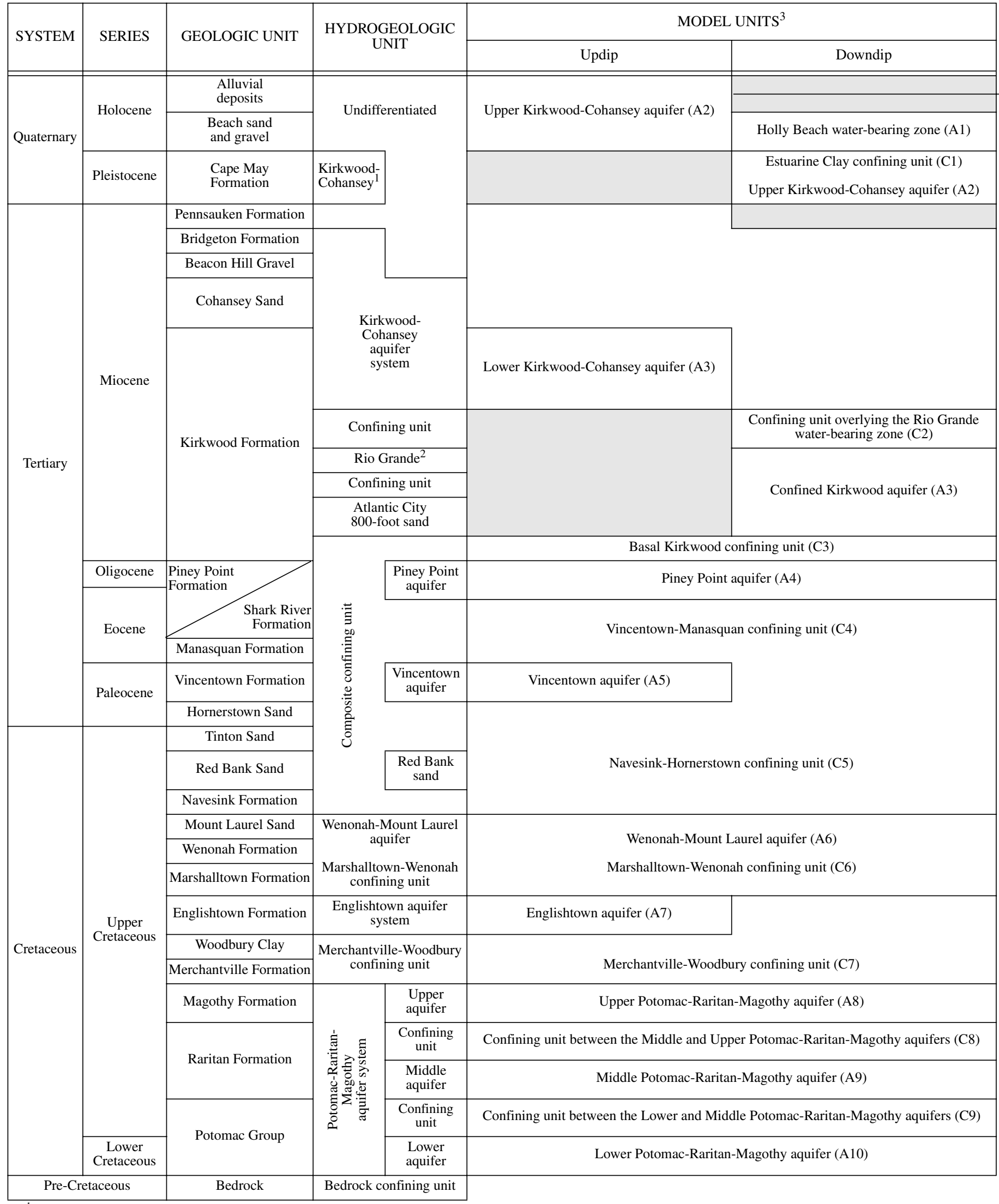

${ }^{1}$ Kirkwood-Cohansey aquifer system.

${ }^{2}$ Rio Grande water-bearing zone.

' $A$ ' refers to modeled aquifer. 'C' refers to modeled confining unit, number refers to model unit. 


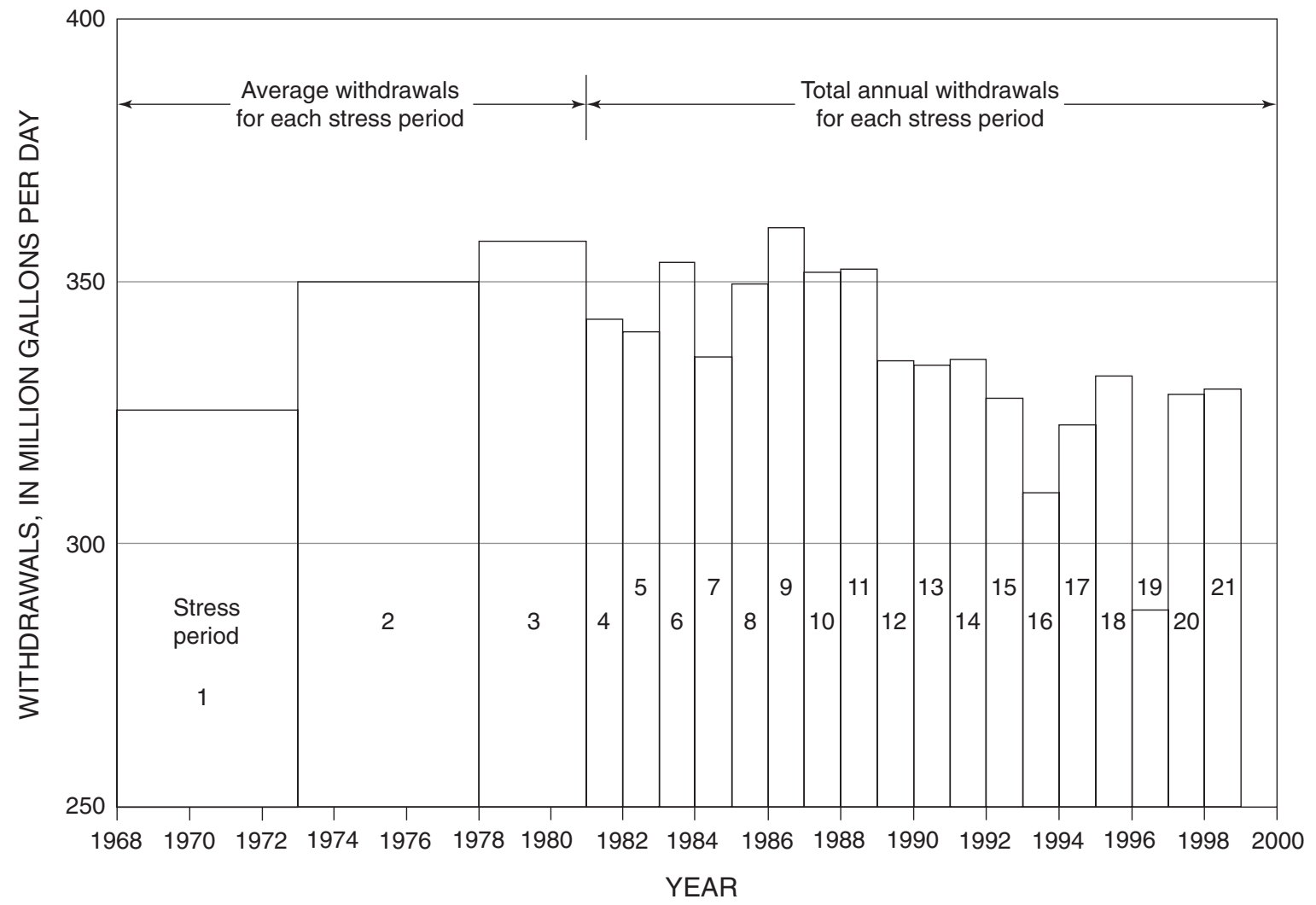

Figure 4. Average and total annual ground-water withdrawals for each stress period for the New Jersey Coastal Plain, 1968-98. 


\section{Lateral and Lower Boundary Conditions}

The model boundaries in the revised model are the same as those used in the 11-layer RASA model (plate 1). The model boundaries are shown in a cross section view in figure 3. A summary of the boundary conditions is given here. For a detailed discussion of the model boundaries and the different boundaries used for the 11-layer RASA model, refer to Martin (1998).

The generalized lateral boundaries shown in plate 1 are not the same in every aquifer simulated in the model, but vary slightly among aquifers. The northwestern updip limit of all model layers is the limit of the Coastal Plain sediments, which is located at or within $15 \mathrm{mi}$ of the Fall Line. The updip limit of the aquifers is modeled as a no-flow boundary.

The Coastal Plain sediments overlie crystalline bedrock, and the lower boundary of the model is at this contact. It is likely that no flow occurs between the Coastal Plain sediments and the crystalline bedrock. This boundary also is modeled as a no-flow boundary.

The lateral model boundaries in the northeast and southwest are specified-flux boundaries that originally were derived from a model of the North Atlantic Coastal Plain (Leahy and Martin, 1993) for the RASA model. For the model by Leahy and Martin, the model area extends from Long Island, New York, to North Carolina and includes all of the New Jersey Coastal Plain. The northeast and southwest boundaries roughly approximate a flow line, and specified fluxes were applied only in areas where the aquifer intersects the flow boundary.

Flows at the lateral boundaries in the northeast and southwest for stress periods 1 to 3 are those used in the original RASA model. Flows at the lateral boundaries for stress periods 4 to 21 for all aquifers, except the Potomac-Raritan-Magothy aquifer system for stress periods 19 to 21, were calculated by using the New Jersey Coastal Plain model constructed by Pope and Gordon (1999). Flows at the lateral boundaries in the Potomac-Raritan-Magothy aquifer system for stress periods 19 to 21 also were calculated by using the model by Pope and Gordon (1999), except those at the Delaware and New Jersey boundary. Outward lateral fluxes were increased in those stress periods to reflect the large increase in ground-water withdrawals in Delaware. The increase in boundary flows was necessary to ensure that simulated water levels would match the water levels in the cone of depression that has developed in the Potomac-RaritanMagothy aquifer system at the Delaware and New Jersey State line since 1988. The lateral boundary flow for each stress period and the ground-water withdrawals for each aquifer are listed in table 3.

The southeastern downdip boundary in the Potomac-Raritan-Magothy aquifer system is a stationary no-flow boundary and is located at the downdip limit of freshwater in the aquifer. The downdip limit of freshwater was determined by Meisler (1980) and is shown on the potentiometic-surface maps presented later in this report.

The southeastern boundary in the confined Kirkwood aquifer and the upper Kirkwood-Cohansey aquifer is also a specified-flux boundary. The lateral boundary flows for stress periods 1 to 3 are those used in the RASA model. The lateral boundary flows for stress periods 4 to 21 were calculated by using the New Jersey Coastal Plain model constructed by Pope and Gordon (1999).

The Englishtown aquifer system and the Wenonah-Mount Laurel, Vincentown, and Piney Point aquifers (table 2) are not continuous throughout the New Jersey Coastal Plain. The limit of these aquifers in the southeast is modeled as a no-flow boundary.

\section{Upper Boundary Conditions}

The upper boundary of the model is a head-dependent-flux boundary in cells that represent the stream reaches in the model area. The stream stage was estimated from 1:24,000 USGS topographic maps of the model area. The streambed conductance was estimated as the product of the streambed hydraulic conductivity, length of stream reach, and stream width divided by the streambed thickness. The streambed conductance is an aggregate parameter that represents all of the factors that affect flow between the aquifer and the stream.

In onshore areas, the upper boundary is a recharge boundary where all applied ground-water recharge flows downward through confining units and aquifers or laterally into aquifers. In offshore areas, the upper boundary is a constant freshwater equivalent water level. The recharge rate and stream stage were kept constant for all stress periods of the transient model. The recharge rate and stream stage are represented by long-term averages and do not reflect seasonal variations. The simulation of yearly hydrologic conditions with long-term averages for recharge and stream stage is consistent with the conceptual model that represents each stress period with average yearly hydrologic conditions.

\section{Streams}

A fine grid-cell size allows for a better representation of the streams in the model area. Because of the original large cell size in the RASA model, each cell represented at least one reach of a stream, and in many cells, various reaches of a stream were represented. Consequently, the stream stage for each original cell represented an average stage for a large reach of a stream or various stream reaches. The average stream stage in the new grid is for a stream reach with a maximum length of $4,226 \mathrm{ft}$, in contrast to $23,796 \mathrm{ft}$ in the RASA grid. Model cells that represent the streams in the study area are shown in figure 5. Cells in the new grid that represent streams were identified by using geographic information system (GIS) coverages of the model grid (generated for this study) and streams (digitized from USGS 1:24,000 topographic maps).

The drain and river packages of MODFLOW-96 were used to simulate the streams in the model area. The river package was used to simulate losing and gaining areas of the Delaware River and Raritan Bay. Continually gaining streams, located in other areas, were simulated with the drain package. 
Table 3. Average daily ground-water withdrawals from each aquifer and lateral boundary flows by stress period, New Jersey Coastal Plain, 1968-98 [All values are in million gallons per day. Positive boundary flows are out of model area, negative boundary flows are into model area.]

\begin{tabular}{|c|c|c|c|c|c|c|c|c|c|c|c|c|}
\hline \multirow{3}{*}{$\begin{array}{c}\text { Model layer } \\
\text { number }\end{array}$} & \multicolumn{12}{|c|}{ Stress period } \\
\hline & 1 & 2 & 3 & 4 & 5 & 6 & 7 & 8 & 9 & 10 & 11 & 12 \\
\hline & $\begin{array}{c}1 / 1968- \\
1 / 1973\end{array}$ & $\begin{array}{c}1 / 1973- \\
1 / 1978\end{array}$ & $\begin{array}{c}1 / 1978- \\
1 / 1981\end{array}$ & 1981 & 1982 & 1983 & 1984 & 1985 & 1986 & 1987 & 1988 & 1989 \\
\hline A1 & 0.08 & 0.11 & 0.17 & 0.24 & 0.25 & 0.25 & 0.16 & 0.01 & 0.01 & 0.01 & 0.01 & 0.01 \\
\hline A2 & 38.93 & 43.87 & 48.57 & 60.06 & 57.85 & 61.77 & 64.07 & 74.55 & 80.69 & 77.38 & 74.35 & 71.26 \\
\hline A3 & 30.42 & 36.95 & 38.02 & 23.08 & 23.30 & 23.44 & 23.29 & 23.96 & 26.50 & 25.58 & 24.16 & 25.35 \\
\hline A4 & 1.48 & 1.97 & 2.00 & 1.81 & 2.02 & 1.97 & 1.79 & 1.77 & 2.12 & 2.01 & 2.11 & 1.84 \\
\hline A5 & 0.09 & 0.94 & 1.15 & 1.47 & 1.02 & 1.14 & 1.00 & 0.99 & 1.23 & 1.36 & 1.94 & 1.50 \\
\hline A6 & 4.65 & 4.56 & 4.97 & 4.65 & 4.66 & 6.05 & 6.07 & 6.28 & 6.84 & 6.50 & 7.65 & 7.78 \\
\hline A7 & 11.33 & 11.95 & 11.27 & 11.17 & 10.52 & 10.10 & 9.99 & 10.51 & 10.59 & 10.72 & 10.48 & 10.04 \\
\hline A8 & 85.93 & 84.79 & 85.44 & 81.99 & 85.91 & 87.39 & 81.24 & 81.58 & 83.15 & 81.52 & 75.87 & 74.92 \\
\hline A9 & 80.92 & 91.81 & 91.79 & 81.59 & 80.14 & 81.68 & 73.21 & 74.67 & 79.54 & 79.38 & 82.21 & 75.92 \\
\hline A10 & 71.83 & 73.95 & 74.82 & 76.41 & 74.34 & 79.67 & 74.17 & 75.20 & 69.34 & 67.25 & 73.59 & 66.11 \\
\hline Total & 325.66 & 350.9 & 358.2 & 342.47 & 340.01 & 353.46 & 334.99 & 349.52 & 360.01 & 351.71 & 352.37 & 334.73 \\
\hline $\begin{array}{l}\text { Net boundary } \\
\text { flow }\end{array}$ & -3.2 & -5.2 & -5.6 & 1.1 & 1.1 & 1.1 & 1.1 & 1.1 & 1.1 & 1.1 & 1.1 & 1.1 \\
\hline
\end{tabular}

\section{Model layer}

A1 - Holly Beach water-bearing zone

A2 - Upper Kirkwood-Cohansey aquifer

A3 - Lower Kirkwood-Cohansey and confined Kirkwood aquifers

A4 - Piney Point aquifer

A5 - Vincentown aquifer

A6 - Wenonah-Mount Laurel aquifer

A7 - Englishtown aquifer system

A8 - Upper Potomac-Raritan-Magothy aquifer

A9 - Middle Potomac-Raritan-Magothy aquifer

A10 - Lower Potomac-Raritan-Magothy aquifer 
Table 3. Average daily ground-water withdrawals from each aquifer and lateral boundary flows by stress period, New Jersey Coastal Plain, 1968-98_-Continued

\begin{tabular}{|c|c|c|c|c|c|c|c|c|c|}
\hline \multirow[b]{2}{*}{$\begin{array}{c}\text { Model layer } \\
\text { number }\end{array}$} & \multicolumn{9}{|c|}{ Stress period } \\
\hline & $\begin{array}{c}13 \\
1990\end{array}$ & $\begin{array}{c}14 \\
1991\end{array}$ & $\begin{array}{c}15 \\
1992\end{array}$ & $\begin{array}{c}16 \\
1993\end{array}$ & $\begin{array}{c}17 \\
1994\end{array}$ & $\begin{array}{c}18 \\
1995\end{array}$ & $\begin{array}{c}19 \\
1996\end{array}$ & $\begin{array}{c}20 \\
1997\end{array}$ & $\begin{array}{c}21 \\
1998\end{array}$ \\
\hline A1 & 0.01 & 0.09 & 0.01 & 0.09 & 0.08 & 0.07 & 0.03 & 0.16 & 0.17 \\
\hline A2 & 83.00 & 95.63 & 95.30 & 83.43 & 93.73 & 100.70 & 83.53 & 112.10 & 105.14 \\
\hline $\mathrm{A} 3$ & 22.66 & 22.80 & 20.90 & 21.93 & 23.99 & 23.07 & 21.37 & 24.15 & 24.40 \\
\hline A4 & 1.87 & 2.23 & 2.29 & 3.32 & 3.25 & 2.89 & 3.60 & 3.81 & 4.50 \\
\hline A5 & 1.24 & 1.73 & 1.62 & 1.77 & 1.46 & 1.33 & 1.36 & 1.46 & 1.50 \\
\hline A6 & 6.56 & 6.16 & 6.33 & 6.78 & 6.39 & 7.72 & 6.31 & 10.19 & 9.15 \\
\hline A7 & 9.19 & 7.20 & 6.98 & 6.94 & 6.95 & 7.43 & 6.49 & 8.94 & 7.78 \\
\hline A8 & 73.94 & 72.22 & 69.38 & 68.28 & 66.38 & 66.19 & 59.04 & 62.64 & 67.26 \\
\hline A9 & 72.60 & 68.14 & 66.40 & 64.74 & 63.82 & 63.64 & 57.98 & 59.94 & 62.24 \\
\hline $\mathrm{A} 10$ & 62.77 & 58.83 & 58.53 & 52.23 & 57.08 & 59.23 & 47.45 & 44.61 & 47.96 \\
\hline Total & 333.84 & 335.03 & 327.74 & 309.51 & 323.13 & 332.27 & 287.16 & 328.00 & 330.10 \\
\hline $\begin{array}{c}\text { Net boundary } \\
\text { flow }\end{array}$ & 0.4 & 0.4 & 0.4 & 0.4 & 0.4 & 0.4 & 0.9 & 0.9 & 0.9 \\
\hline
\end{tabular}

\section{Model layer}

A1 - Holly Beach water-bearing zone

A2 - Upper Kirkwood-Cohansey aquifer

A3 - Lower Kirkwood-Cohansey and confined Kirkwood aquifers

A4 - Piney Point aquifer

A5 - Vincentown aquifer

A6 - Wenonah-Mount Laurel aquifer

A7 - Englishtown aquifer system

A8 - Upper Potomac-Raritan-Magothy aquifer

A9 - Middle Potomac-Raritan-Magothy aquifer

A10 - Lower Potomac-Raritan-Magothy aquifer 


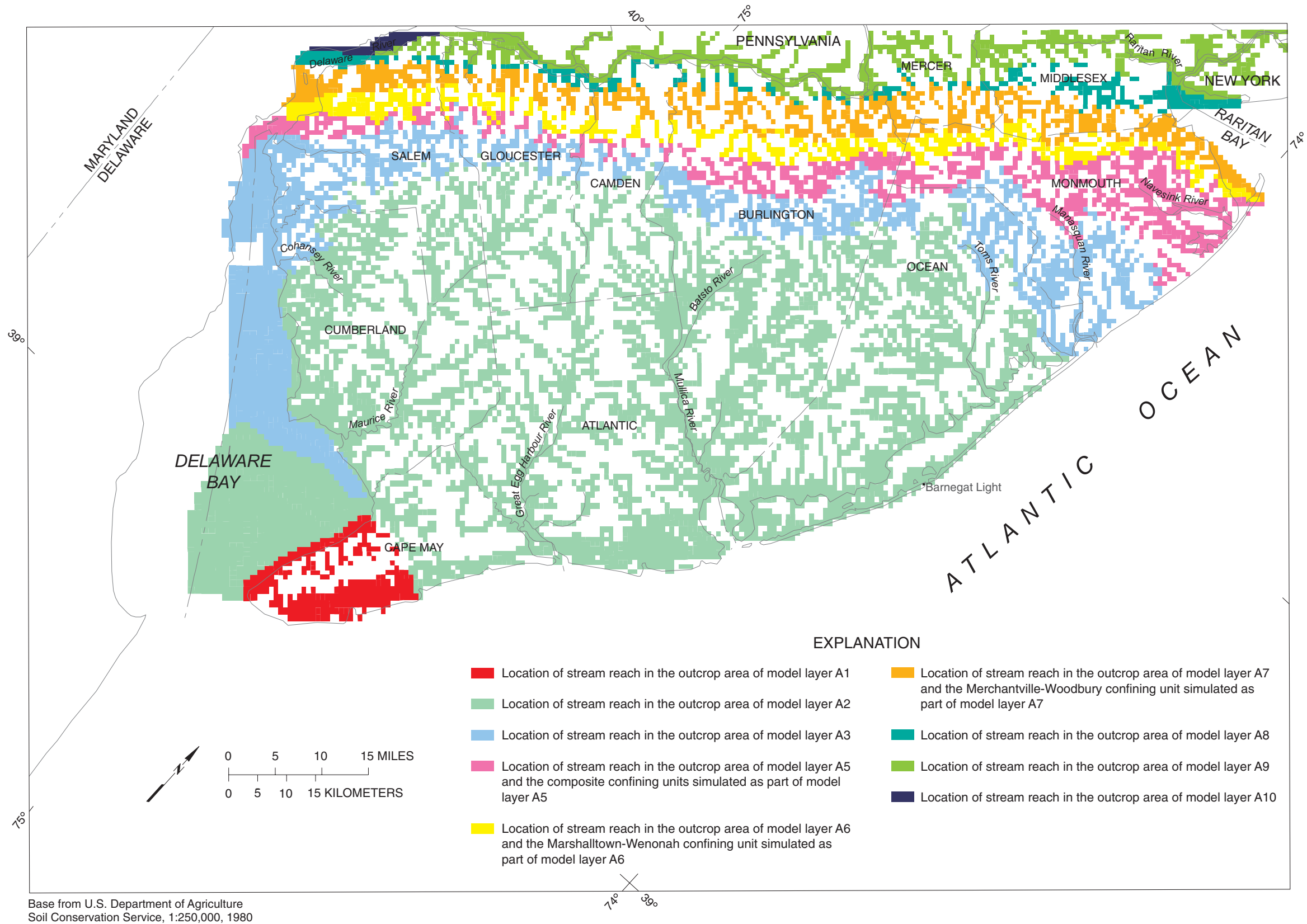

Figure 5. Model cells that represent stream reaches in the study area, New Jersey Coastal Plain. 


\section{Recharge}

The upper model boundary includes a spatially variable recharge rate applied at cells that represent the outcrop area of aquifers and confining units without wetlands. The recharge rate applied to the outcrop areas represents long-term precipitation minus long-term evapotranspiration and surface-water runoff. The amount of precipitation that results in surface-water runoff is related to the topography and lithology of the outcrop areas. The spatially variable recharge rate reflects these changes in the outcrop areas of eight aquifers and three confining units in the Coastal Plain. The Piney Point aquifer, the Lower Potomac-Raritan-Magothy aquifer, the Estuarine Clay confining unit, and the confining unit overlying the Rio Grande waterbearing zone (table 2) do not crop out in the model area and receive no recharge at the upper model boundary. The confining unit between the Middle and Upper Potomac-Raritan-Magothy aquifers and the confining unit between the Lower and Middle Potomac-Raritan-Magothy aquifers either crop out under the Delaware River or are simulated as receiving no recharge at the upper model boundary because the width of the outcrop area is negligible, less than $0.5 \mathrm{mi}$. Zapecza (1989) does not map an outcrop area for these confining units. Barton and Kozinski (1991) and Lewis and others (1991) show these units to have limited outcrop areas, less than 0.5 mile wide in their respective study areas.

The precipitation that recharges the outcrop areas eventually flows to surface-water bodies, such as streams or the ocean, and is referred to as ground-water discharge. Ground-water discharge can be local flow to nearby streams within the shallow aquifer system, intermediate flow along long flow paths (miles) beneath nearby streams that discharge to neighboring larger streams, or regional flow that moves through confining units to confined aquifers and eventually discharges to large rivers and (or) the ocean.

\section{Model Calibration}

The revised model was calibrated by trail-and-error adjustment of the vertical-leakance values, storage-coefficient values, streambed-conductance values, lateral-boundary fluxes, and recharge rates. Recharge rates were adjusted in areas where no previous studies were conducted that determined a recharge rate. During model calibration, it was found that changes to only the five model parameters listed above improved the RASA model calibration in any particular area; therefore, these parameters were changed from the RASA model-input data. These five parameters were adjusted during model calibration in order to minimize the difference between simulated and measured values of one or more of the following: (1) estimated base flow for five river basins, (2) water levels in 28 selected observation wells for which long-term hydrographs were available, and (3) potentiometric surfaces for 1978, 1983, 1988, 1993, and 1998 conditions.
Simulated 1978 potentiometric surfaces from the RASA and revised model also were compared during model calibration. The objective of comparing the simulated potentiometric surfaces from the RASA model and revised model was to ensure that the original level of calibration was maintained or improved.

\section{Revisions to Model Input Data}

In the following four sections, the revisions to the modelinput data for the revised model are described.

\section{Recharge}

The recharge rates are based on values determined by studies conducted in the New Jersey Coastal Plain and by model calibration. The recharge rates are shown in figure 6 , and the locations of the study areas are shown in figure 7 . The recharge rates range from $0.01 \mathrm{in} / \mathrm{yr}$ in the outcrop area of the composite confining unit to $20 \mathrm{in} / \mathrm{yr}$ in the Cohansey aquifer. The recharge rates used in this model are long-term averages and regional estimates. These rates do not reflect seasonal or local variations, which do occur.

Recharge was applied to the modeled outcrop area of three confining units because, on the basis of simulation results, a small amount of recharge could be percolating through the confining units to the underlying aquifers. Recharge to confiningunit outcrops could not be simulated directly because confining units are not represented with a layer of cells in the model, but only with vertical-leakance characteristics. Therefore, recharge to confining-unit outcrops is applied to cells with zero transmissivity in the layer that represents the overlying aquifer. The outcrop areas of confining units $\mathrm{C} 5, \mathrm{C} 6$, and $\mathrm{C} 7$ are labeled p5, p6, and 7 , respectively, in figure 3 and are simulated as part of the aquifer overlying the confining unit. For example, the confining unit outcrop area labeled $\mathrm{p} 5$ is simulated as part of the aquifer labeled a5. In these areas (p5, p6, and p7 in figure 3), no horizontal flow to the aquifer results, only vertical flow through the outcrop area of the confining unit to the underlying aquifer.

\section{Vertical Leakance}

The vertical leakance was adjusted for the Navesink-Hornerstown confining unit (fig. 8). The vertical-leakance values were decreased a maximum of three orders of magnitude in the vicinity of the wells shown in figure 8 , which are screened in the Vincentown and Wenonah-Mount Laurel aquifers, to obtain a better match between the simulated and long-term measured water levels in these wells. Simulated water levels for well 29139 , which is screened in the Vincentown aquifer, are $6 \mathrm{ft}$ closer to measured water levels in 1978 than in the original RASA model. Simulated water levels in well 25-486, which is screened in the Wenonah-Mount Laurel aquifer, are $15 \mathrm{ft}$ closer to measured water levels in 1985 than in the original RASA model. All other vertical-leakance values used in the revised 


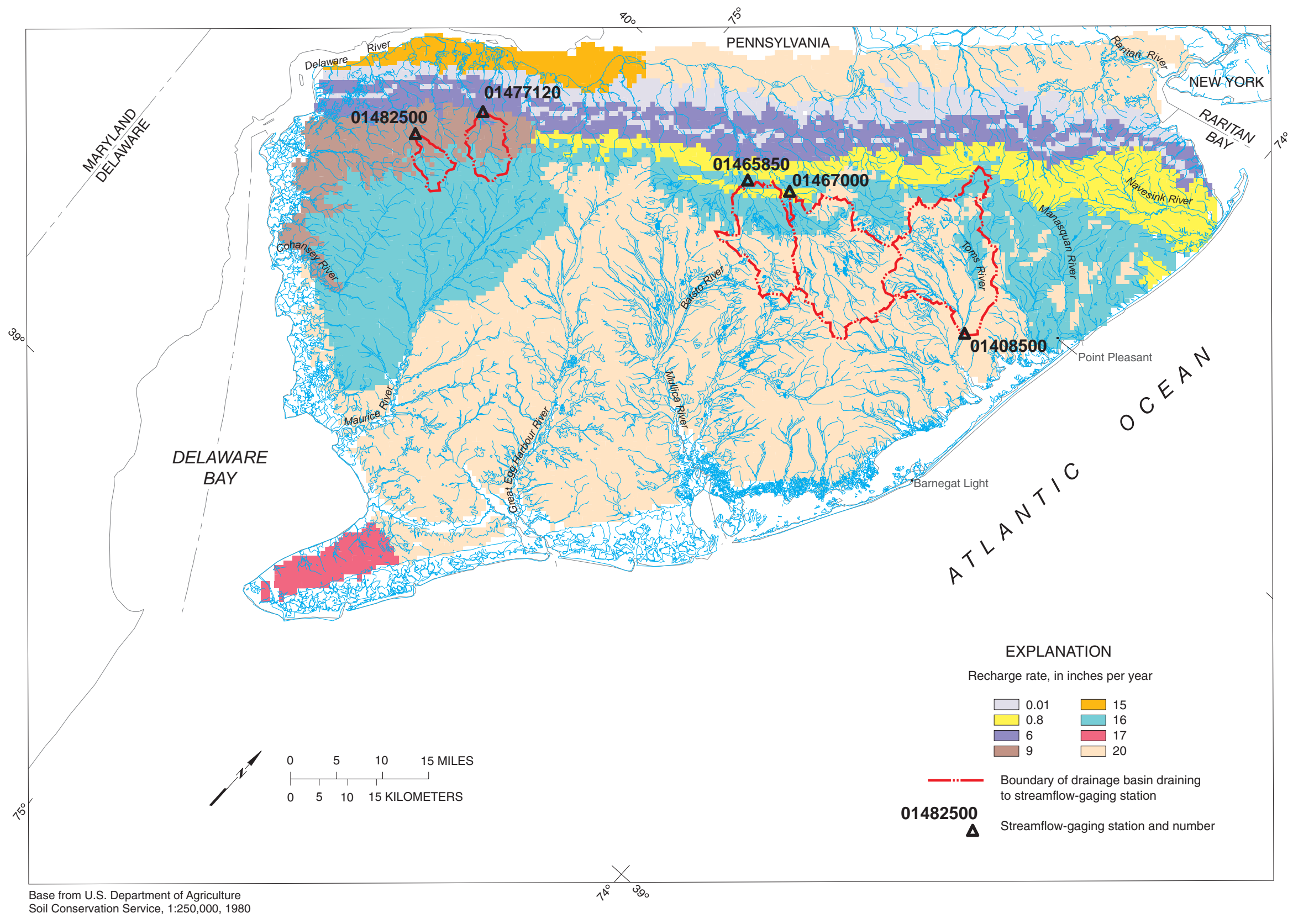

Figure 6. Recharge rates used in the model and the location of selected drainage basins and streamflow-gaging stations in the model area, New Jersey Coastal Plain. 
Lacombe, P.J. and Rosman, R., 1995, Hydrology of the unconfined aquifer system in the upper Maurice River basin and adjacent areas in Gloucester County, New Jersey, 1986-87: U.S. Geological Survey Water-Resources Investigations Report 92-4128, 5 sheets
Johnson, M.L., and Charles, E.G., 1997, Hydrogeology of the unconfined aquifer system, Salem River area: Salem River and Racoon, Oldmans, Alloway, and Stow Creek Basins, New Jersey, 1993-94: U.S. Geological Survey WaterResources Investigations Report 96-5195, 5 sheets

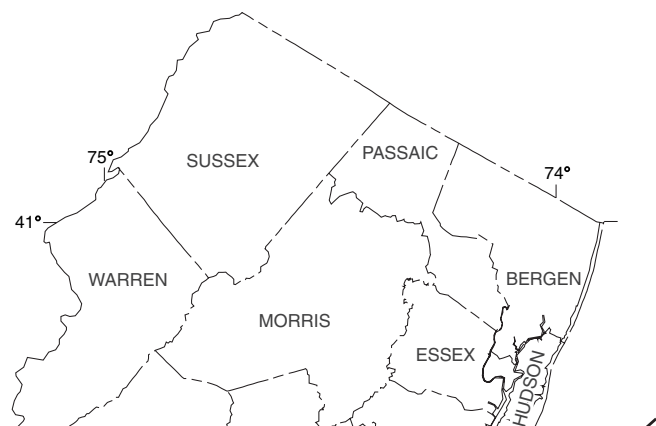

Wane, A.C, Charles, E. G., and Storck, D.A., 2003, Hydrology of the unconfined aquifer system, Rancocas Creek area: Rancocas, Crosswicks, Assunpink, Blacks, and Crafts Creek Basins, New Jersey, 1996: U.S. Gelogical Survey Water-Resources Investigations Report $02-4280,5$ sheets

Watt, M.K., Johnson, M.L. and

Lacombe, P.J., 1994

Hydrology of the unconfined aquifer system, Toms River, Metedeconk River, and Kettle Creek Basins, New Jersey, 1987-90:

U.S. Geological Survey WaterResources Investigations Report 93-4110, 5 sheets.

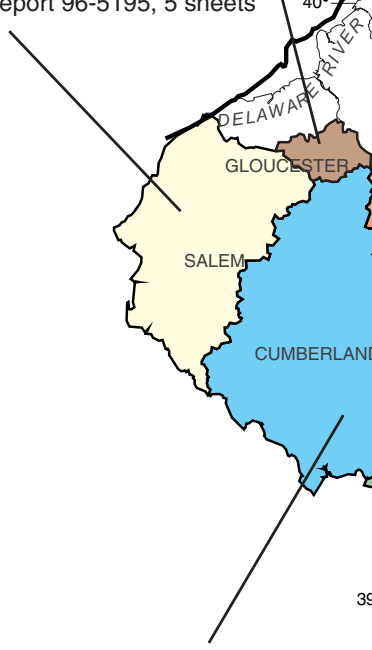

Charles, E.G., Storck, D.A., and Clawges, R.M., 2001,

Hydrogeology of the unconfined aquifer system, Maurice River area: Maurice and Cohansey River basins, New Jersey, 1994-95 U.S. Geological Survey Water-Resources Investigations Report 01-4229, 5 sheets

Spitz, F.J., 1998, Analysis of ground-water flow and saltwater encroachment in the shallow aquifer system of Cape May County, New Jersey: U.S. Geological Survey Water-Supply Paper 2490, $51 \mathrm{p}$

Figure 7. Location of, and references for, studies that reported ground-water recharge rates in the New Jersey Coastal Plain. 


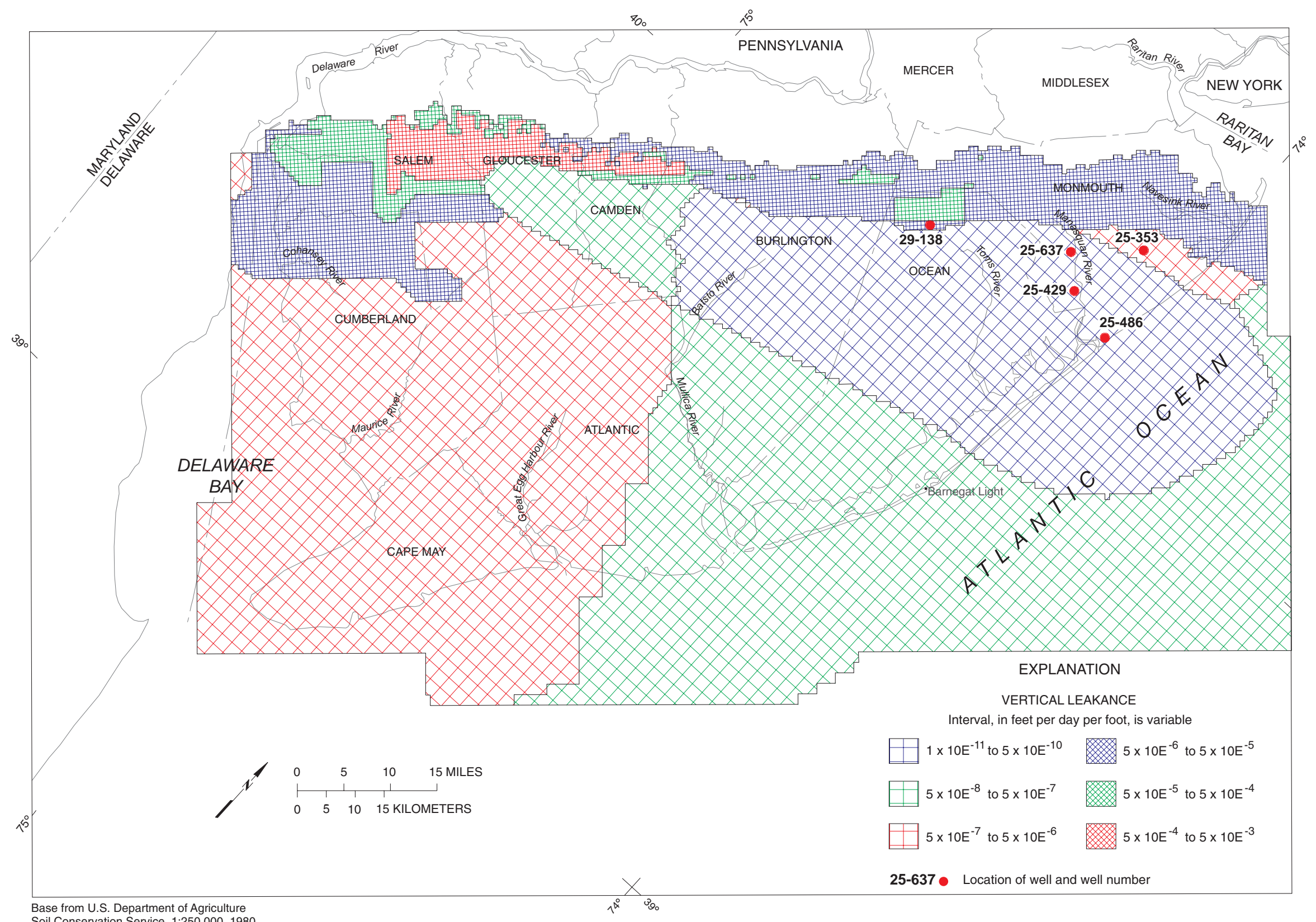


model are from the original RASA model. The simulation of long-term water levels is presented in the "Simulated and Measured Water-Level Hydrographs" section.

\section{Storage Coefficient}

A storage coefficient of 0.0001 was used in the RASA model for most areas of confined aquifers. The exceptions are the downdip areas of the three Potomac-Raritan-Magothy aquifers in Monmouth and Ocean Counties, where storage coefficients ranging from $5 \times 10^{-4}$ to $8 \times 10^{-4}$ were used. A better match was achieved with a storage coefficient of 0.001 between simulated and measured water levels at well 25-486 screened in the Wenonah-Mount Laurel aquifer. Water levels in the Wenonah-Mount Laurel aquifer and Englishtown aquifer system in Critical Water Supply Area 1 (fig. 1) have risen more than $100 \mathrm{ft}$ since 1988 as a result of the decrease in groundwater withdrawals. During model calibration, it was found that storage coefficient is an important parameter in the recovery of water levels in this area.

The simulated water levels for well 25-486 (fig. 9) result from two model scenarios, one with a storage coefficient of 0.001 and the other with 0.0001 . Simulated water levels that result from a storage coefficient of 0.0001 initially matched measured water levels at well 25-486 but began to diverge with the decrease in withdrawals in 1989. It appears that ground water flowing into this area is expanding the aquifer material and (or) is being compressed (water levels not increasing) rather than increasing water levels.

During model calibration, the simulated recharge rate in the Wenonah-Mount Laurel aquifer outcrop area was increased and decreased without any effect on the water levels in the cone of depression in the Wenonah-Mount Laurel aquifer located in the Point Pleasant, Ocean County, N.J., area (fig. 6). The transmissivity of the Wenonah-Mount Laurel aquifer is low, from 500 to $1,000 \mathrm{ft}^{2} / \mathrm{d}$. Because of the low transmissivities, recharge water that enters at the outcrop area does not flow downdip. An increase or decrease of the transmissivities of the Wenonah-Mount Laurel aquifer resulted in simulated water levels that were higher or lower than measured water levels in wells in this area (fig. 9). An increase or decrease of the transmissivities also resulted in simulated water levels that did not match the curve of the hydrograph of measured water levels shown in figure 9.

The vertical leakance of the confining units that overlie (Navesink-Hornerstown) and underlie (Marshalltown-

Wenonah) the Wenonah-Mount Laurel aquifer also was changed during model calibration. An increase or decrease of the vertical leakance of the Marshalltown-Wenonah confining unit resulted in simulated water levels that were too high or too low in the Wenonah-Mount Laurel aquifer. A decrease of the vertical leakance of the Navesink-Hornerstown confining unit resulted in a better match with the measured water levels prior

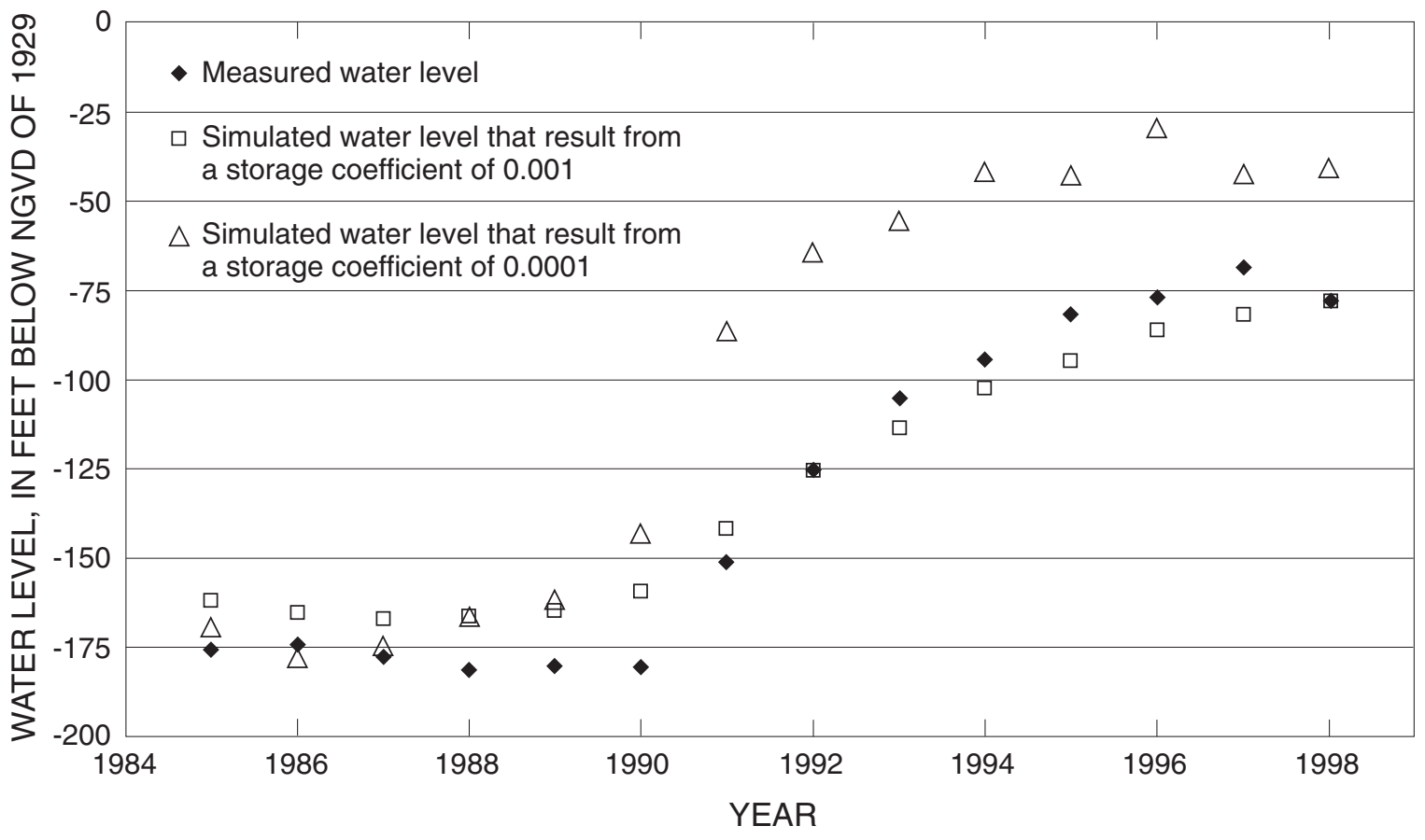

Figure 9. Hydrographs of measured and simulated water levels in well 25-486 screened in the Wenonah-Mount Laurel aquifer that result from two model scenarios with storage coefficients of 0.001 and 0.0001, New Jersey Coastal Plain, $1985-98$. (Well location shown in fig. 22) 
to the decrease in ground-water withdrawals that began in 1989. Simulated water levels after 1990 for the scenario with a storage coefficient of 0.0001 were as much as $83 \mathrm{ft}$ higher than measured water levels (1991). Again, all of these simulations resulted in water levels that did not match the curve of the hydrograph of measured water levels shown in figure 9 . The measured water levels in well 25-486 have been increasing since 1989 (fig. 9), which indicates that water levels have not reached steady-state conditions.

\section{Boundary Fluxes}

To simulate the eastern part of a regional cone of depression that has developed around wells in the Lower PotomacRaritan-Magothy aquifer in Delaware, boundary fluxes near the Delaware and New Jersey State line were adjusted during model calibration until a reasonable match was achieved between the measured and simulated water levels in this area in 1998. The fluxes at this boundary were increased $0.5 \mathrm{Mgal} / \mathrm{d}$ from the $4.1 \mathrm{Mgal} / \mathrm{d}$ used in the original RASA model for the Lower Potomac-Raritan-Magothy aquifer. An increase of 0.5 $\mathrm{Mgal} / \mathrm{d}$ at this boundary is less than 0.001 percent of the outflow of the entire model area for 1995.

The total 1997 ground-water withdrawals from the Lower Potomac-Raritan-Magothy aquifer in Delaware was $5.42 \mathrm{Mgal} / \mathrm{d}$ (Lacombe and Rosman, 2001). The location of these withdrawal wells shown in figure 10 is just beyond the active model area. The increased boundary fluxes at the Delaware-New Jersey boundary represent part of the ground-water withdrawals from these wells.

\section{Simulated Potentiometric Surfaces}

During model calibration, the simulated potentiometric surfaces were compared to those from each of the five Coastal Plain synoptic studies conducted in 1978, 1983, 1988, 1993, and 1998 to ensure that cones of depressions and flow directions were simulated throughout the time periods of the study. Discussion of the potentiometric surfaces in this report is limited to 1978 and 1998 ground-water-flow conditions. The interpreted 1978 potentiometric surfaces also were compared to simulated transient-model results to ensure that the same level of calibration was maintained or improved with the revised model. Hydrologic conditions for 1998 are discussed in this report because the 1998 water-level synoptic study provides the most recent water-level data.

\section{Ground-Water-Flow Conditions}

In most areas of each aquifer the interpreted and simulated 1978 potentiometric surfaces compare well, and the level of calibration was maintained or improved. Martin (1998) presents a lengthy discussion of the comparison of the simulated and interpreted potentiometric surfaces, which still is valid for the revised model.
The simulated potentiometric surfaces from the RASA model and the revised model also compare well. The only minor difference in the calibration of the two models is in the cone of depression centered in Point Pleasant, N.J., in the WenonahMount Laurel aquifer and Englishtown aquifer system. The revised model simulates the potentiometric surfaces in the cone of depression in this area to be about 20 and $40 \mathrm{ft}$, respectively, deeper than those of the RASA model. The 1978 interpreted potentiometric surfaces (potentiometric surfaces constructed with measured water levels) in the cones (Walker, 1983) in this area are about 180 and $240 \mathrm{ft}$ below NGVD of 1929, respectively; these potentiometric surfaces compare well with the simulated potentiometric surfaces from the revised model (fig. 11), which are about 160 and $220 \mathrm{ft}$ below NGVD of 1929, respectively. The improvement in the agreement of water levels is because of the smaller grid spacing and the change in the vertical leakance values of the confining unit overlying the Wenonah-Mount Laurel aquifer.

\section{Ground-Water-Flow Conditions}

The simulated and, when available, interpreted potentiometric surfaces for 1998 are shown in figures 12-21. During the 1998 Coastal Plain water-level synoptic study (Lacombe and Rosman, 2001), no water levels were measured in the Holly Beach water-bearing zone, upper Kirkwood-Cohansey aquifer system, or Vincentown aquifer. In general, the interpreted and simulated water levels match closely; in most areas they are within $20 \mathrm{ft}$. The exceptions are in the cone of depression in the Piney Point, Wenonah-Mount Laurel, and Upper PotomacRaritan-Magothy aquifers.

Water levels in the Piney Point aquifer simulated with the RASA model matched measured water levels closely except in the southwestern Coastal Plain and along the Atlantic Coast (Martin, 1998). Martin states that there were few measured water levels available for the Piney Point aquifer and further calibration of the model in this area was not beneficial. Waterlevel data for the Piney Point aquifer still are sparse. The aquifer was not a focus of this current study, and no attempt was made to match measured and simulated water levels with the revised model more closely. The same level of calibration is maintained, however. The maximum difference (40 ft) between 1998 simulated and measured water levels is in the small cone of depression centered near Barnegat Light, N.J. (fig. 15).

The shape and depth of the two small cones of depression located in the Wenonah-Mount Laurel aquifer in Burlington County were not simulated as closely to measured water levels as those in other areas of the aquifer (fig. 17). The difference between the measured and simulated water levels in the cone of depression in northwestern Burlington County is about $40 \mathrm{ft}$. The difference between the measured and simulated water levels in the cone of depression in northeastern Burlington County is about $20 \mathrm{ft}$. The poor match between the simulated and measured water levels could be due to contouring style and (or) 


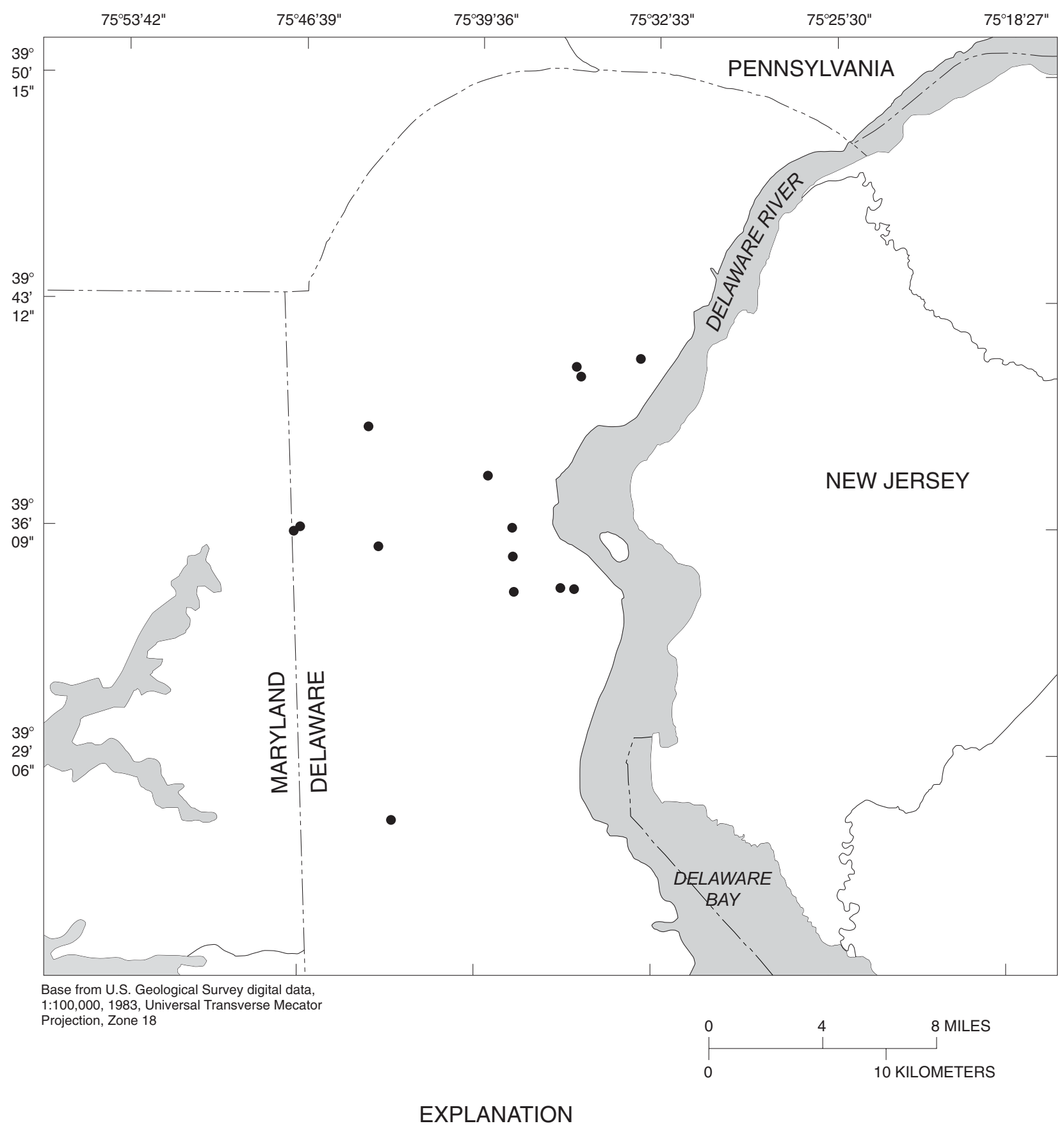

- Location of ground-water withdrawl well

Figure 10. Location of ground-water withdrawal wells screened in the Lower Potomac-Raritan-Magothy aquifer in Delaware, 1997. 
(a)

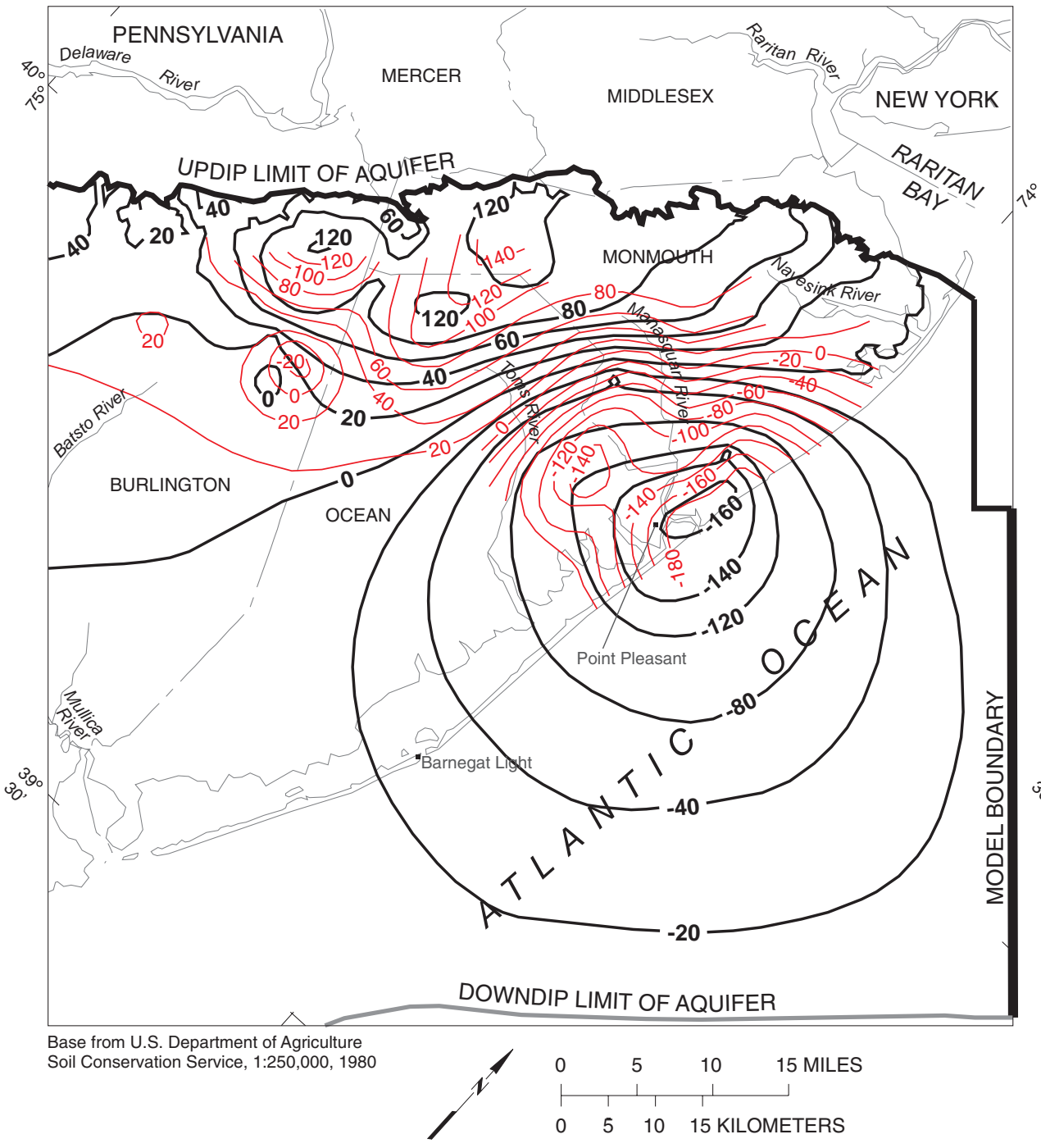

(b)

PENNSYLVANIA
MERCER

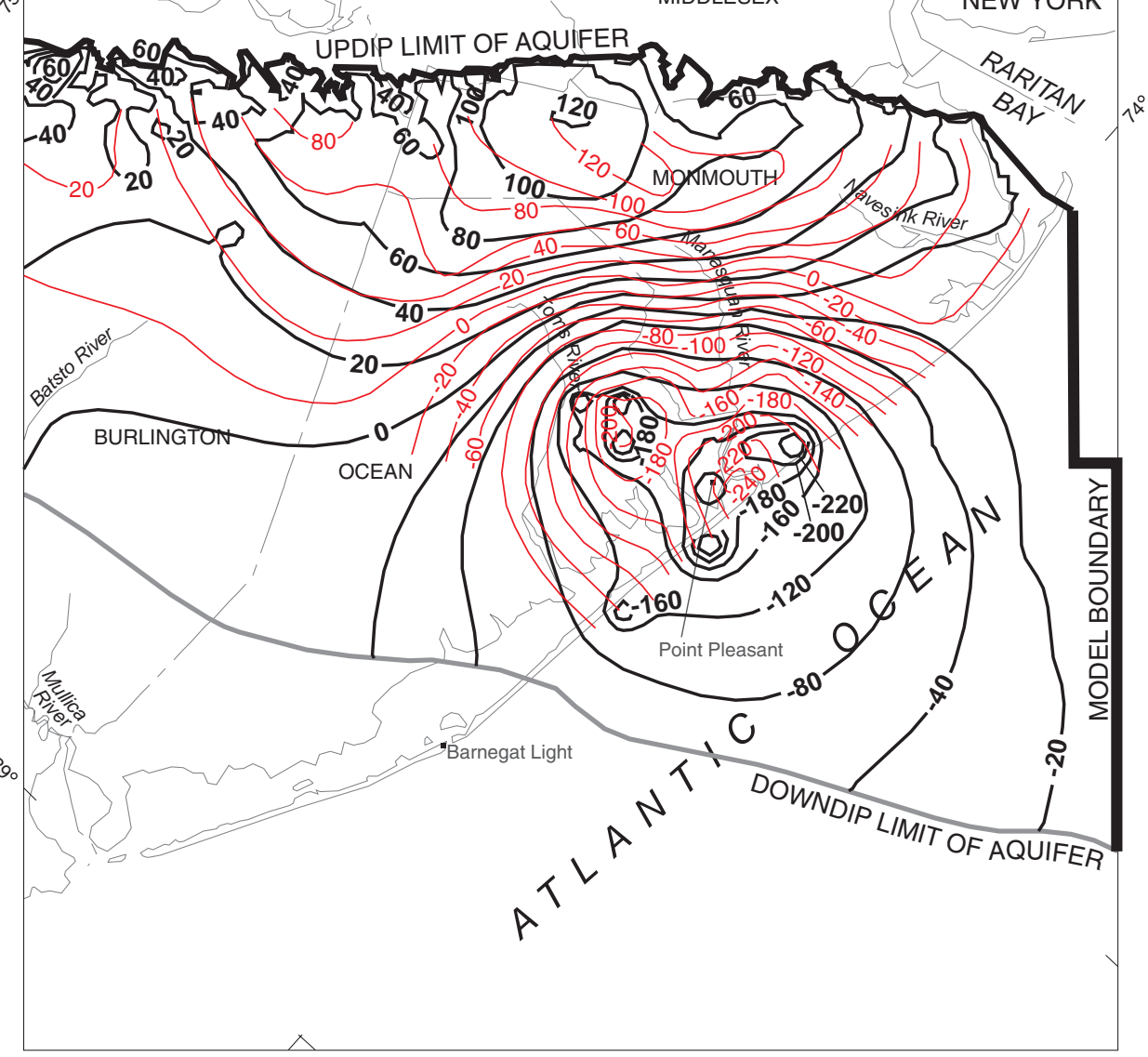

Base from U.S. Department of Agriculture

\section{EXPLANATION}

- 20- SIMULATED POTENTIOMETRIC CONTOUR--Shows simulated altitude at which water level would have stood in tightly cased wells. December 1978. Contour interval 20 and 40 feet. Datum is NGVD of 1929

INTERPRETED POTENTIOMETRIC CONTOUR--Shows interpreted altitude at which water level would have stood in tightly cased wells. Dashed where approximate. Modified from Walker, 1983. Contour interval 20 and
40 feet. Datum is NGVD of 1929

Figure 11. Simulated and interpreted potentiometric surfaces of the (a) Wenonah-Mount Laurel aquifer, (b) Englishtown aquifer system, New Jersey Coastal Plain, 1978. 


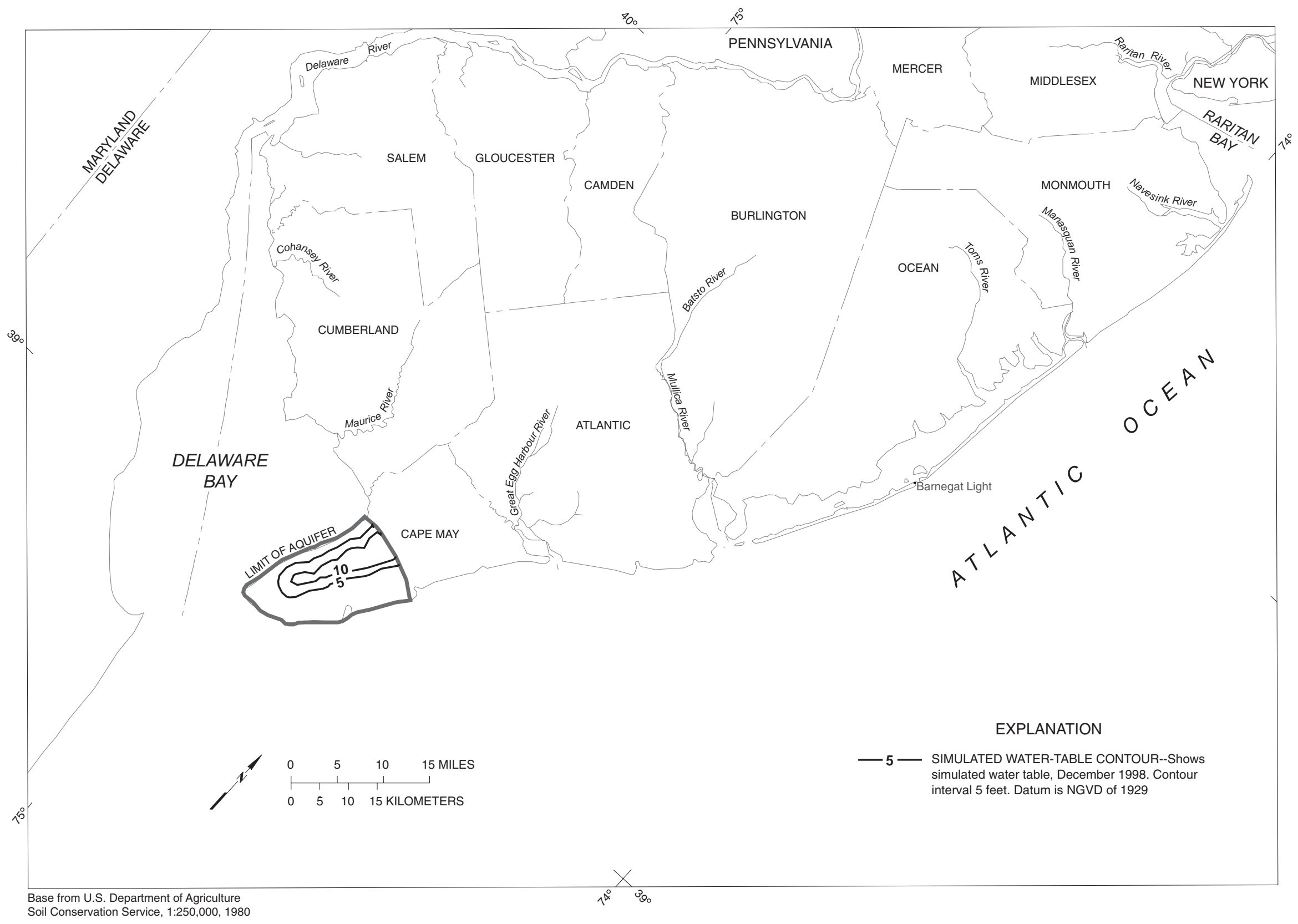

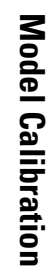

Figure 12. Simulated water table of the Holly Beach water-bearing zone, New Jersey Coastal Plain, 1998. 


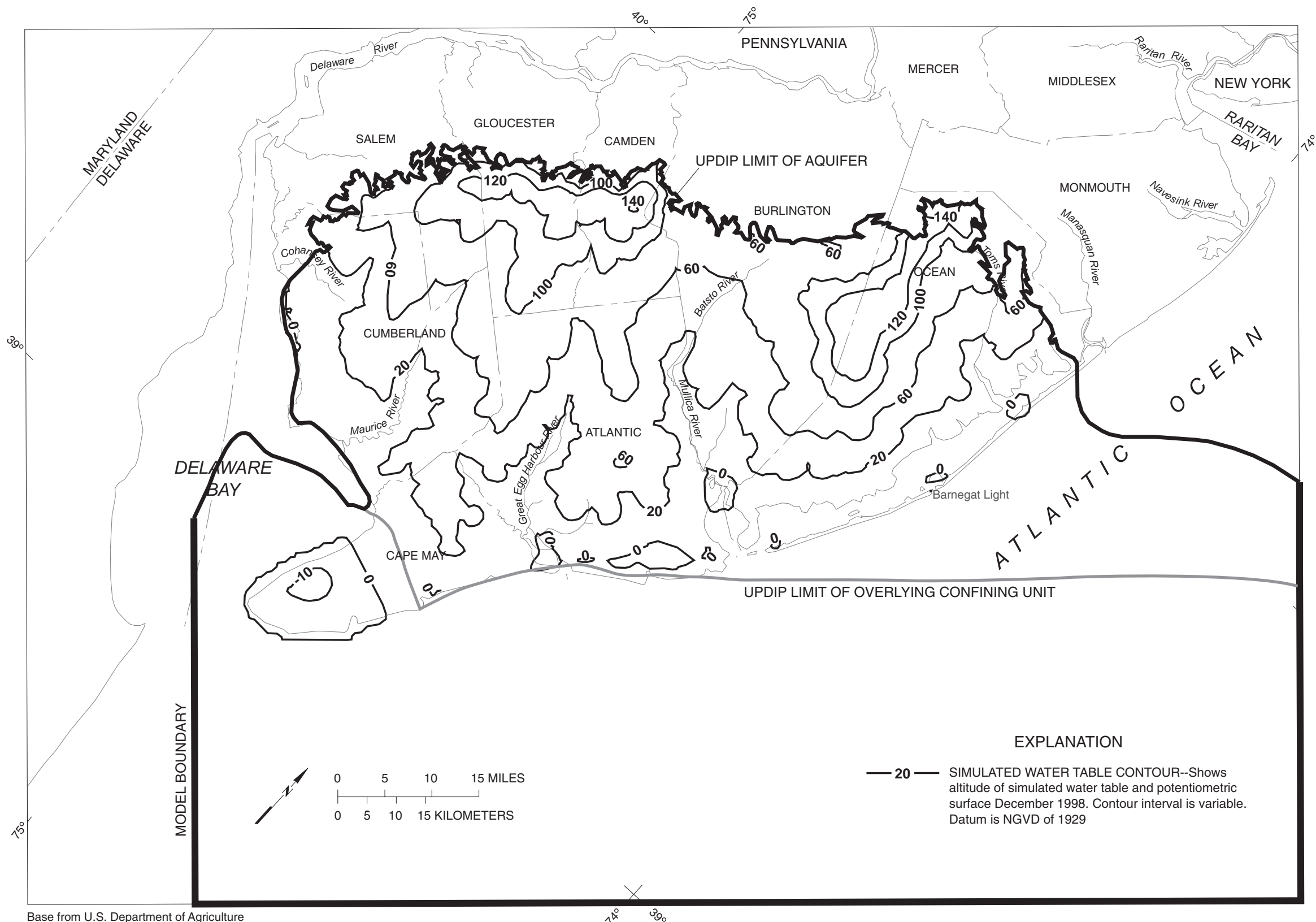

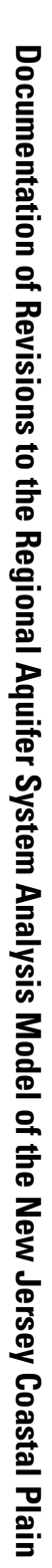
Base from U.S. Department of Agriculture
Soil Conservation Service, $1: 250,000,1980$

Figure 13. Simulated water table and simulated potentiometric surfaces of the upper Kirkwood-Cohansey aquifer system, New Jersey Coastal Plain, 1998. 


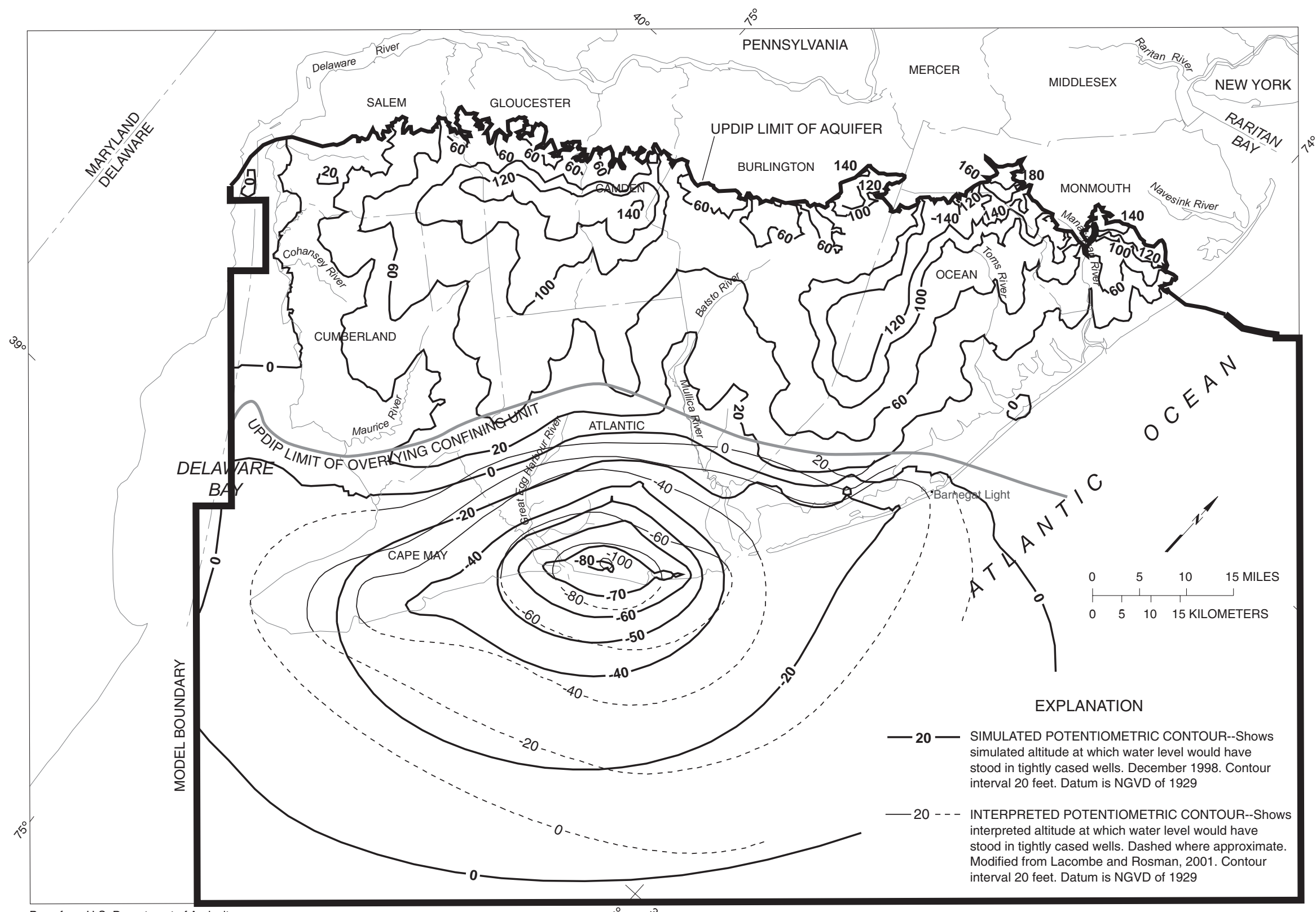

Base from U.S. Department of Agriculture

$1^{1^{2}} 3_{9}^{3}$

Figure 14. Siimulated and interpreted potentiometric surfaces of the lower Kirkwood-Cohansey aquifer system and confined Kirkwood aquifer, New Jersey Coastal Plain, 1998. 


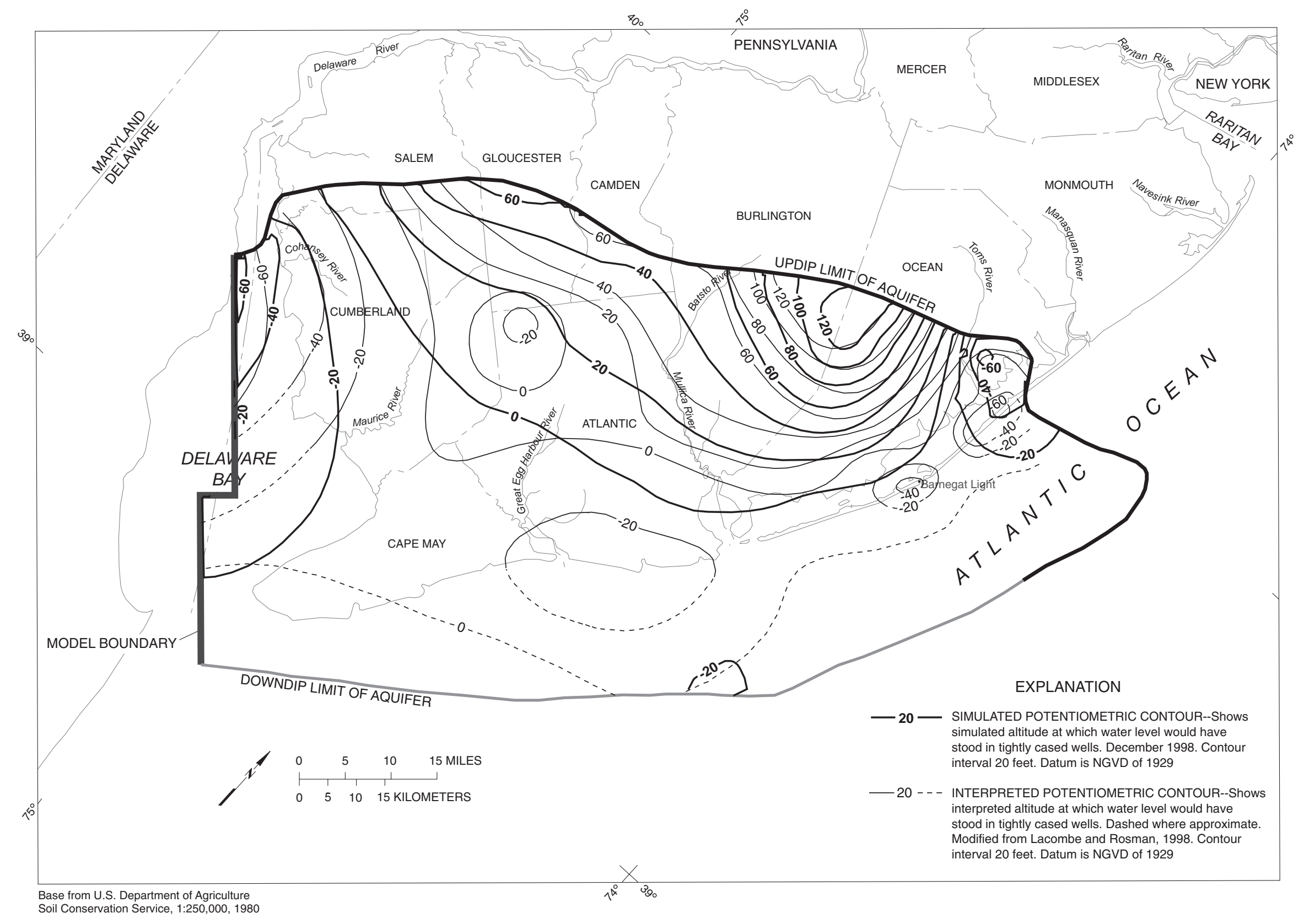

Figure 15. Simulated and interpreted potentiometric surfaces of the Piney Point aquifer, New Jersey Coastal Plain, 1998. 


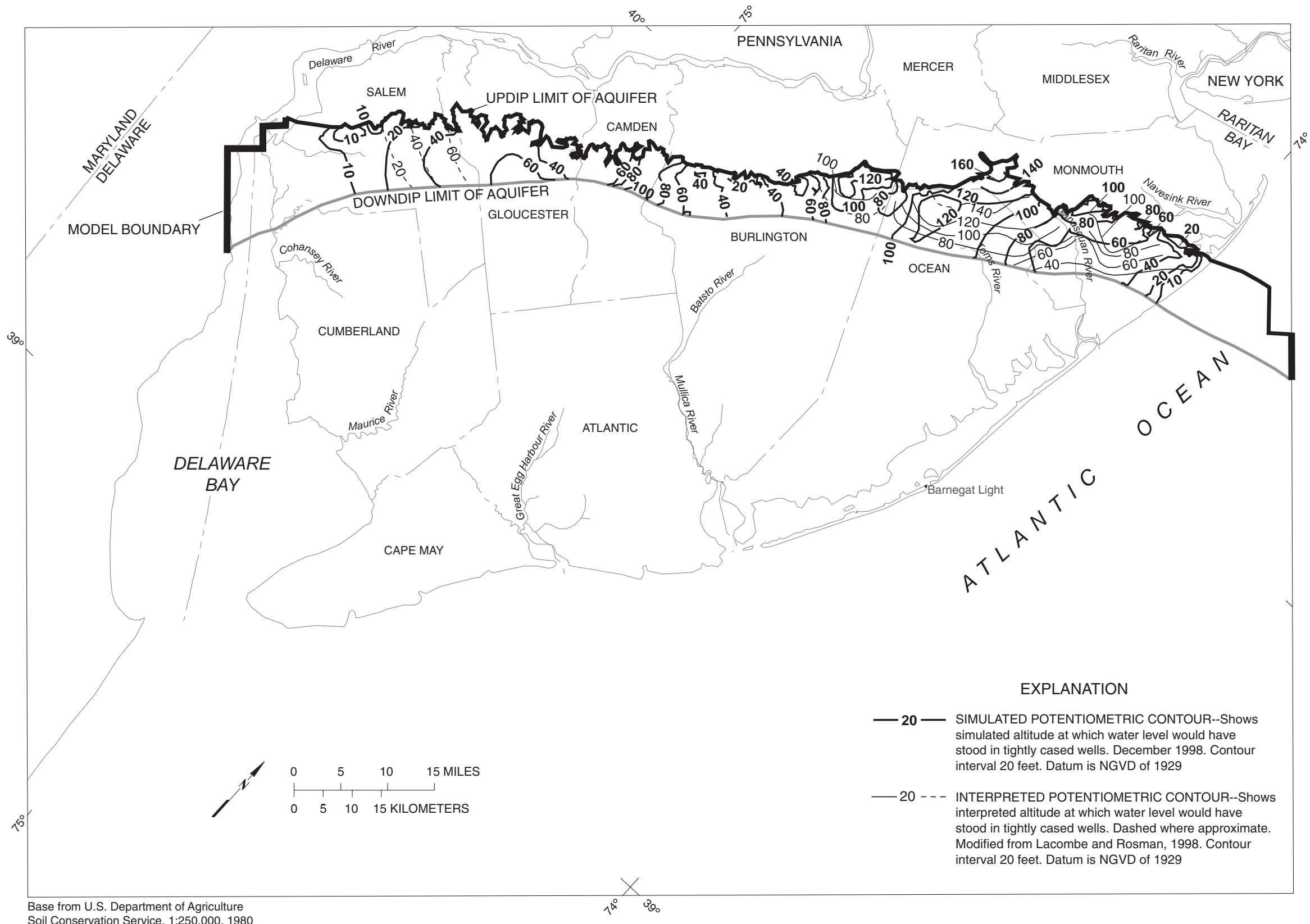

Figure 16. Simulated and interpreted potentiometric surfaces of the Vincentown aquifer, New Jersey Coastal Plain, 1998. 


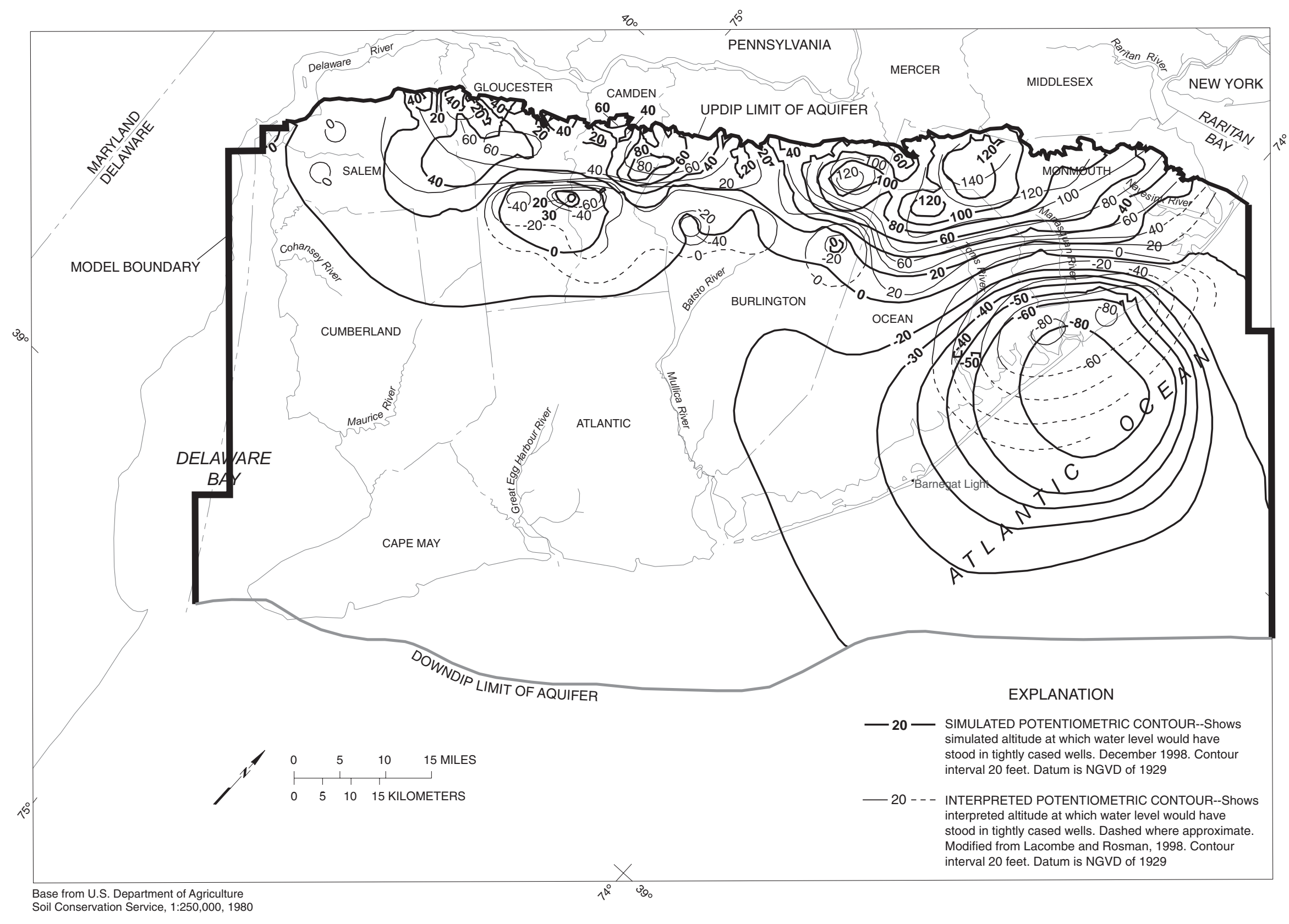

Figure 17. Simulated and interpreted potentiometric surfaces of the Wenonah-Mount Laurel aquifer, New Jersey Coastal Plain, 1998. 


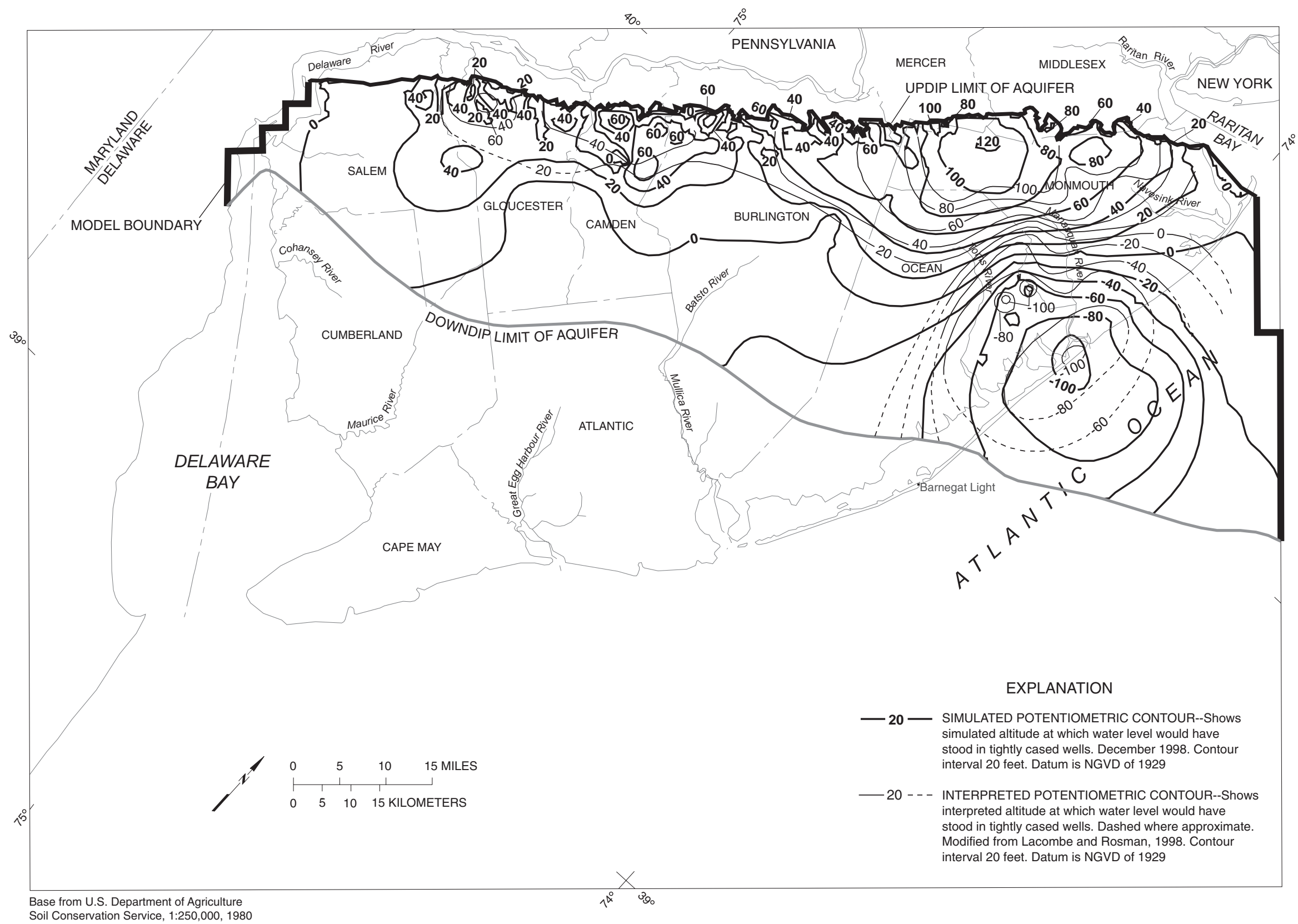

Figure 18. Simulated and interpreted potentiometric surfaces of the Englishtown aquife system, New Jersey Coastal Plain, 1998. 
${ }^{8} 0$

ぷ

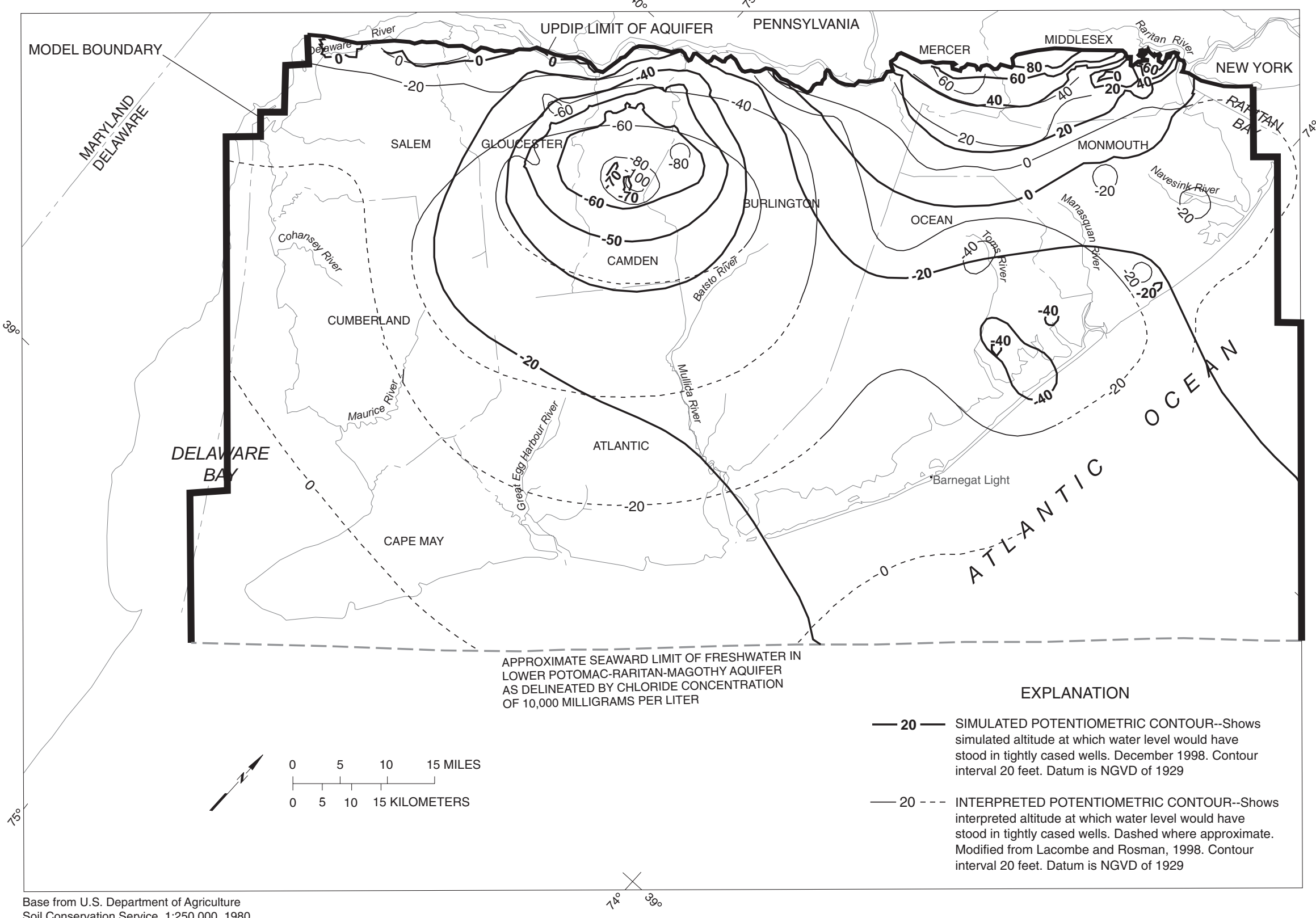

Figure 19. Simulated and interpreted potentiometric surfaces of the Upper Potomac-Raritan-Magothy aquifer, New Jersey Coastal Plain, 1998. 


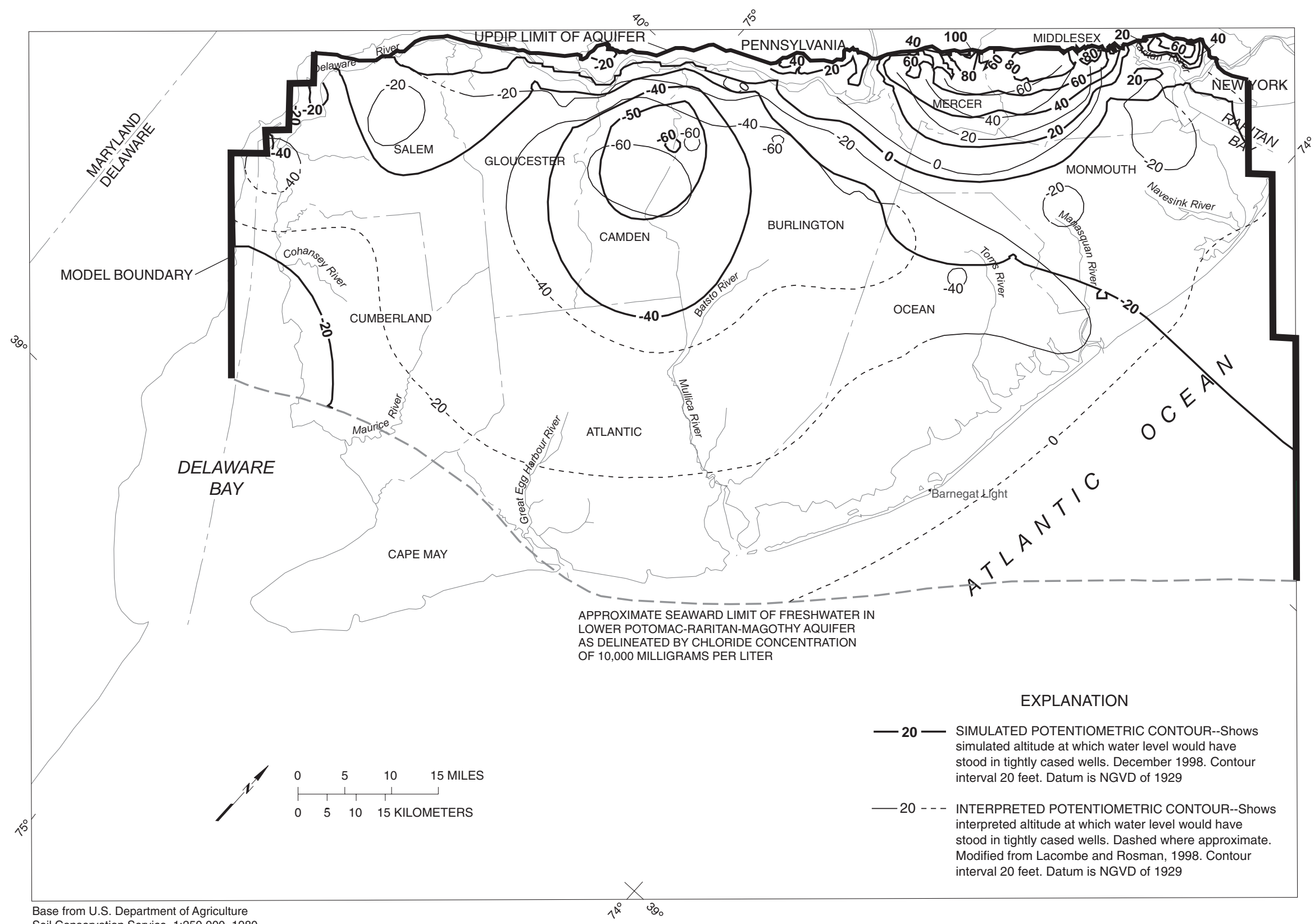

Figure 20. Simulated and interpreted potentiometric surfaces of the Middle Potomac-Raritan-Magothy aquifer, New Jersey Coastal Plain, 1998. 


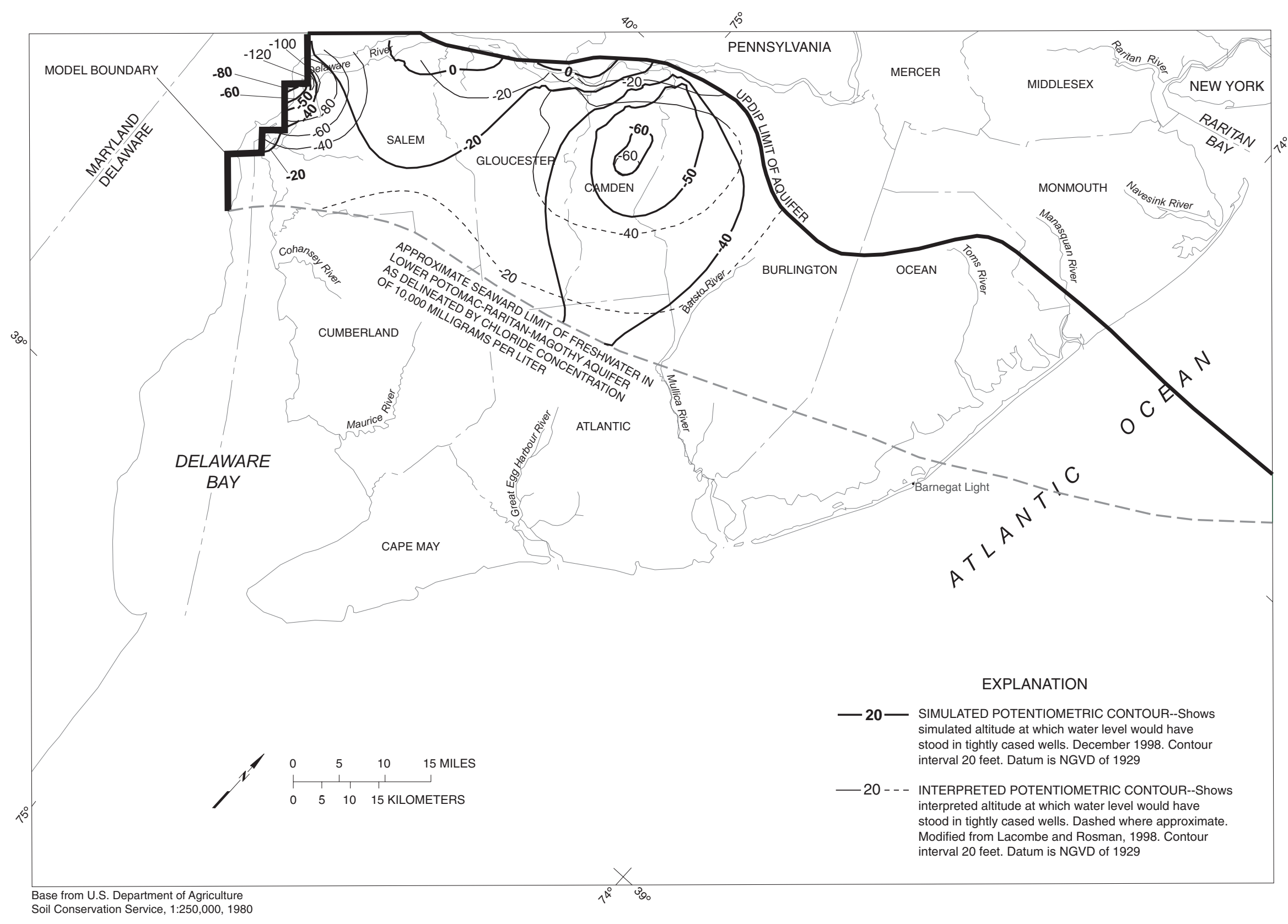

Figure 21. Simulated and interpreted potentiometric surfaces of the Lower Potomac-Raritan-Magothy aquifer, New Jersey Coastal plain, 1998. 
unreported ground-water withdrawals. The NJDEP does not require that ground-water withdrawals less than 100,000 gal/d be reported. The Wenonah-Mount Laurel aquifer has low transmissivity values (500 to $1,000 \mathrm{ft}^{2} / \mathrm{d}$ ), and during model calibration, water levels in the aquifer were found to be sensitive to ground-water withdrawals. Unreported ground-water withdrawals that are not simulated in the model could cause simulated water levels to be higher than measured levels.

The simulated water levels in the Upper Potomac-RaritanMagothy aquifer are as much as $35 \mathrm{ft}$ higher than measured water levels in the cone of depression centered in Camden County (fig. 19). The 1998 simulated water levels were within 10 and $15 \mathrm{ft}$ of measured water levels in wells 5-258 and 7-477 (fig. 22), respectively, which are located on the flanks of this regional cone of depression. Water levels in well 5-258 initially were simulated more closely, within $3 \mathrm{ft}$ of the measured water levels. The difference between the simulated and measured water levels increased beginning in 1983. Determining the specific cause of these differences is beyond the scope of this study.

\section{Simulated and Measured Water-Level Hydrographs}

Long-term hydrographs were plotted for the 28 selected wells shown in figure 22; these hydrographs were used during model calibration. The wells were selected on the basis of location and period of record. Also, when possible, wells used by Martin (1998) were selected. Some of the wells with hydrographs that Martin used during model calibration are no longer monitored; when possible, a nearby well, for which a hydrograph is available, was selected.

Hydrographs of simulated and measured water levels for the 28 wells are shown in figures $23-49$. In general, the simulated water levels are within $25 \mathrm{ft}$ of the measured water levels and, in most cases, are within $5 \mathrm{ft}$.

Wells 1-834, 7-283, 7-477, 7-478, 11-96, and 33-251, which have the greatest differences between simulated and measured water levels, are located near regional cones of depression (fig. 22). The large differences between the simulated and measured water levels could be due to the discretization scale of the model area and (or) unreported ground-water withdrawals. Simulated water levels are an average for each model cell.

Differences in measured water levels among aquifers were compared to differences in simulated water levels at five well clusters located throughout the New Jersey Coastal Plain. The location of well clusters is shown in figure 22. Each well cluster consists of at least two wells in close proximity, screened in two different aquifers. Three of the five well clusters consist of four wells in close proximity; one well is screened in the outcrop area of an aquifer where unconfined conditions are present, and the other three wells are screened in different confined aquifers. Evaluation of the water-level differences among aquifers showed that the direction of flow between confined aquifers and the water table is simulated accurately.

\section{Base Flow}

The simulated and estimated base flows at continuousrecord streamflow-gaging stations in the Toms River, North Branch Rancocas Creek, South Branch Rancocas Creek, Raccoon Creek, and Salem River drainage basins are listed in table 4 , and the location of the sites is shown in figure 6 . These basins were selected because a detailed analysis of base flow was available for each of the rivers and because each river is representative of typical rivers in the New Jersey Coastal Plain. The estimated base-flow values listed in table 4 are the mean base flows for the time period shown in the table. The interval for the calculated mean base flow ranges from 26 to 68 years. The values listed in table 4 for the simulated base flow are the average for the interval of the simulation, 1968-98, from the transient model. The base flow for each river and stress period was calculated. The values were added, then divided by 21 , the number of stress periods. The resulting value is the simulated mean annual base flow.

The simulated and calculated mean base flow in the five river basins compare well; all differences are less than 31 percent. The simulated and calculated base flow at continuousrecord streamflow gaging stations Toms River (01408500) and North Branch Rancocas Creek (01467000), the two large basins, match closely, within 10 percent. Differences are larger between the simulated and calculated base flow at Raccoon Creek (01477120) and Salem River (01482500), the two small basins, 31 and 27 percent, respectively.

\section{Model Limitations}

This revised model of the New Jersey Coastal Plain sediments is a tool for analysis of the regional ground-water-flow system. All models are an approximation of the actual groundwater-flow system. Ground-water-flow models generally are based on conceptual models that are simplified representations of complex heterogeneous systems. Assumptions such as isotropy and vertical homogeneity within each layer are examples of simplified representation that can be a source of simulation errors. Local scale heterogeneities or hydrologic features not represented in the model may affect results. Model parameters were estimated in areas where there is a lack of data, such as water-level measurements. Model parameters, such as transmissivity, ground-water withdrawals, and recharge rates, represent averages for areas that range from $0.25 \mathrm{mi}^{2}$ to $0.32 \mathrm{mi}^{2}$. Local features, such as the maximum depth of a cone of depression, are not simulated with the revised model. Water levels that result from seasonal variations in ground-water withdrawals or recharge rates also are not simulated. 


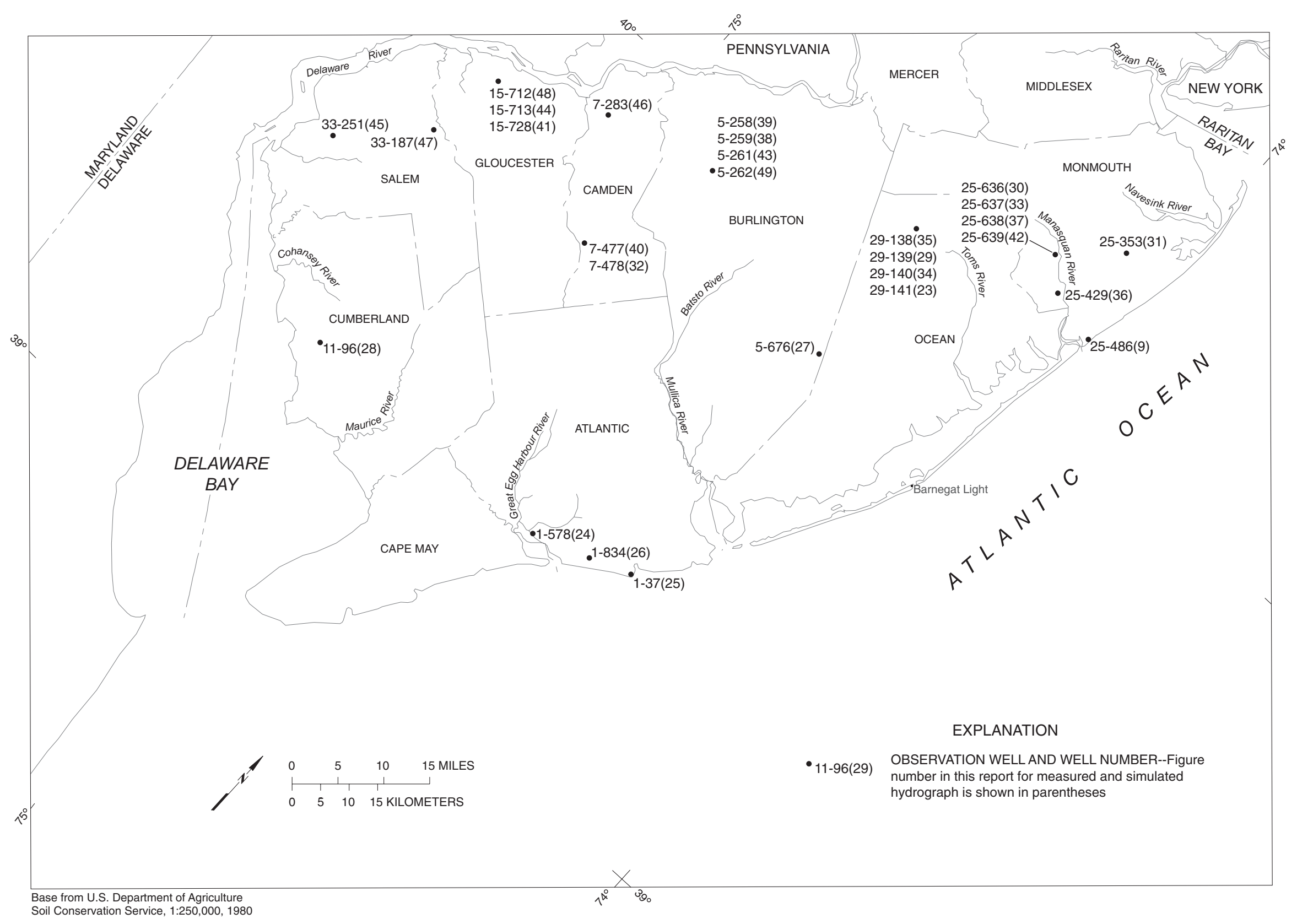

Figure 22. Location of selected observation wells for which hydrographs of simulated and measured water levels have been plotted, New Jersey Coastal Plain. 


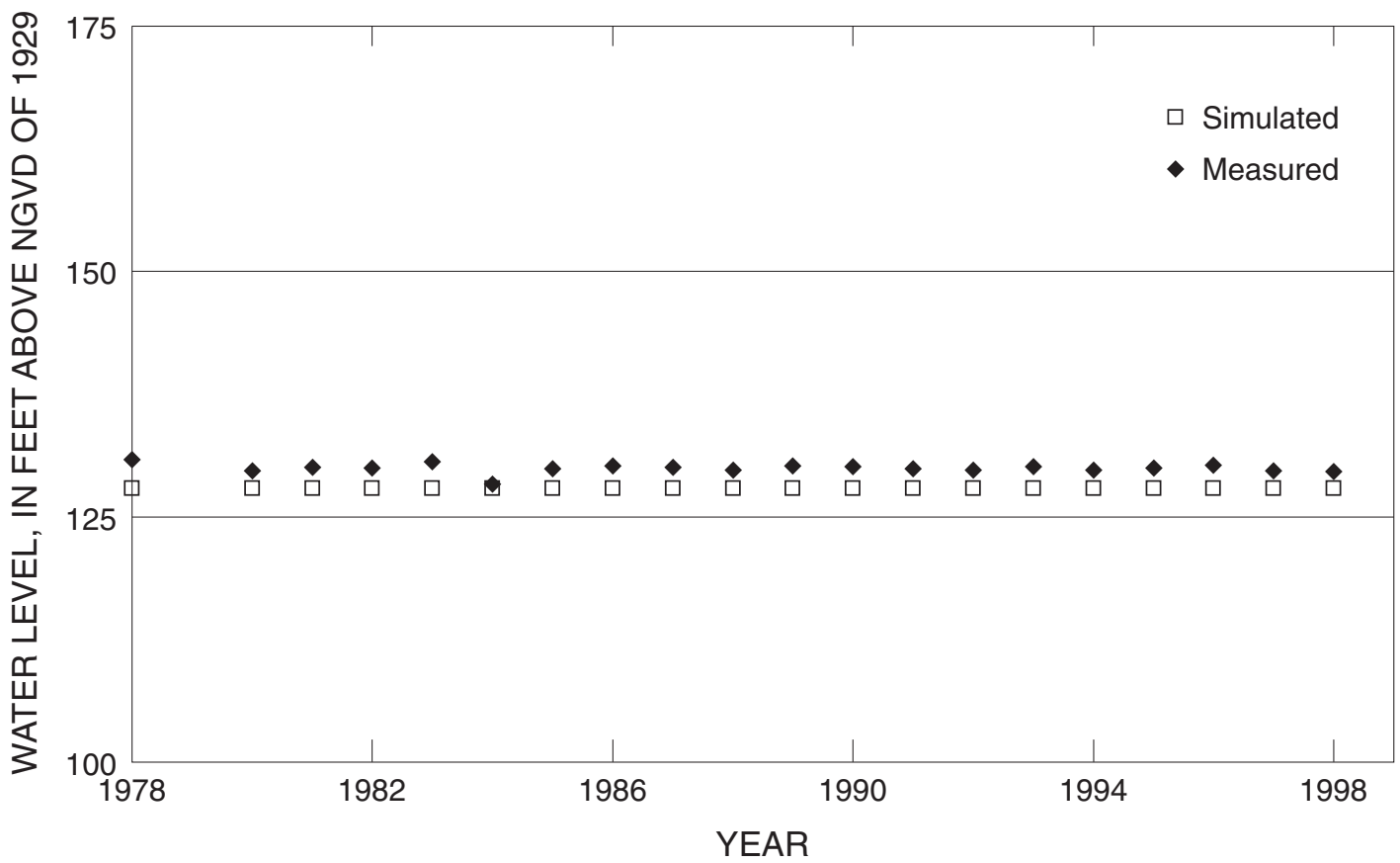

Figure 23. Simulated and mesured water levels for well 29-141 screened in the Kirkwood-Cohansey aquifer system, New Jersey Coastal Plain, 1978-98. (Well location shown in fig. 22)

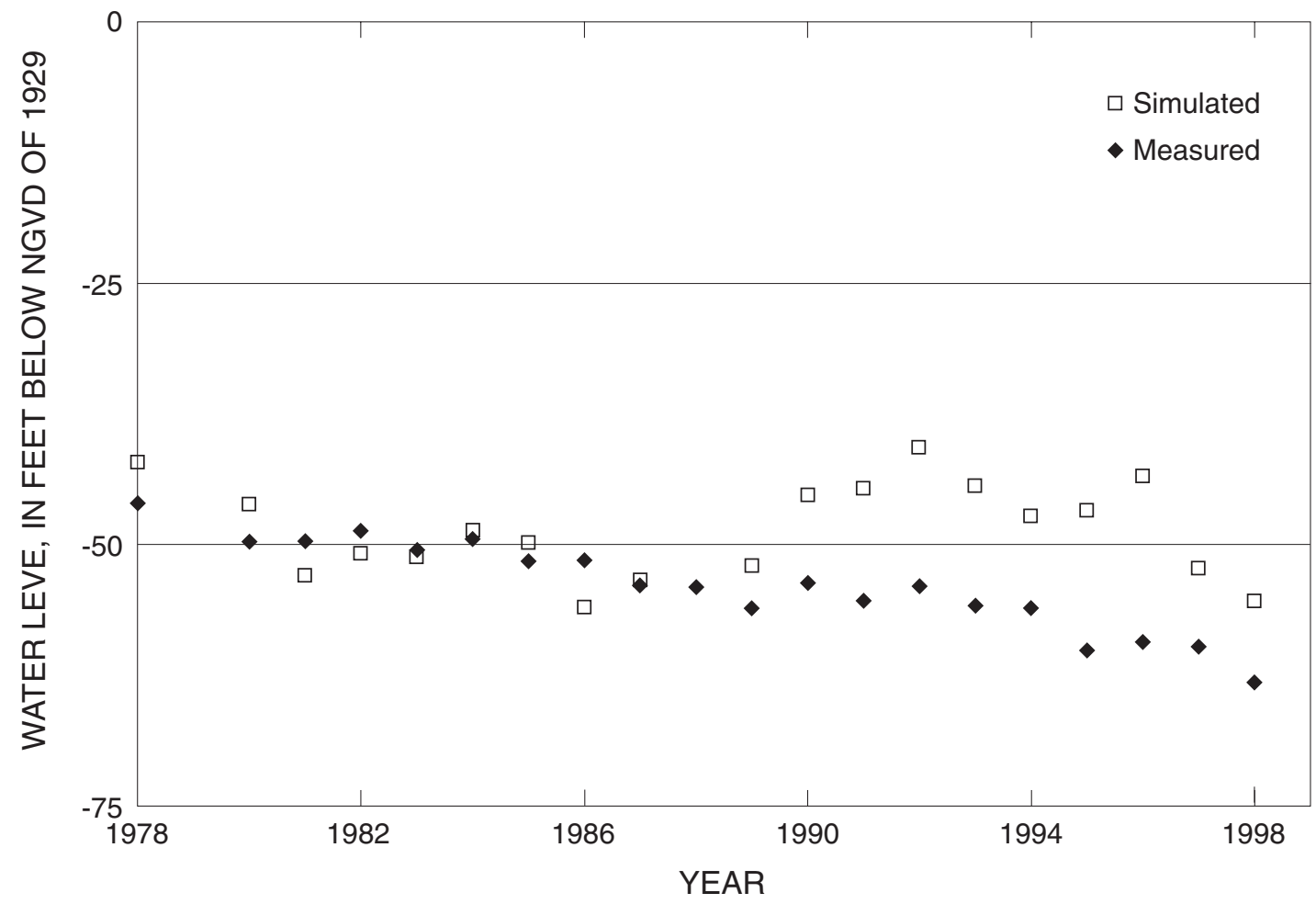

Figure 24. Simulated and measured water levels for well 1-578 screened in the confined Kirkwood aquifer, New Jersey Coastal Plain, 1978-98. (Well location shown in fig. 22) 


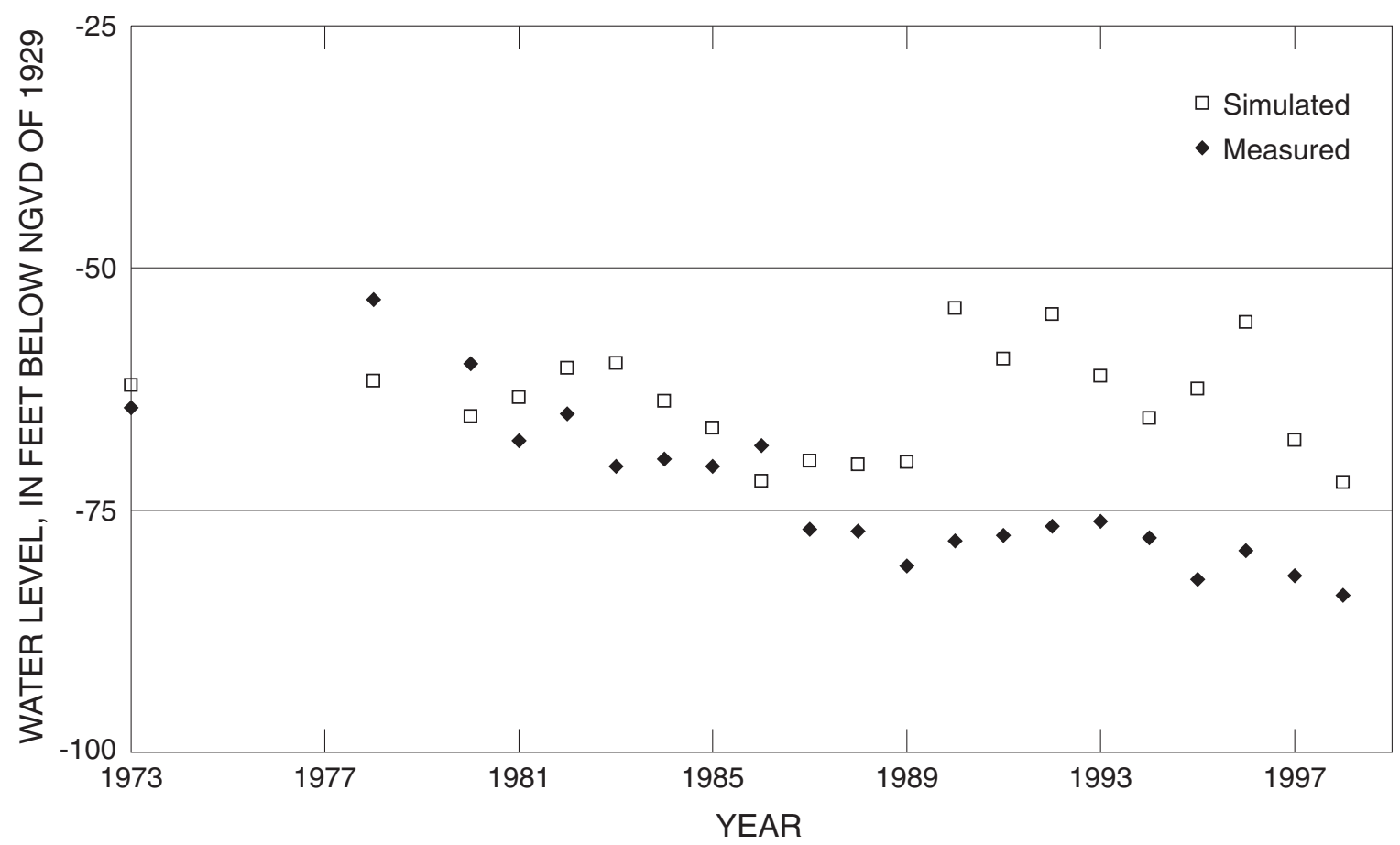

Figure 25. Simulated and measured water levels for well 1-37 screened in the confined Kirkwood aquifer, New Jersey Coastal Plain, 1973-98. (Well location shown in fig. 22)

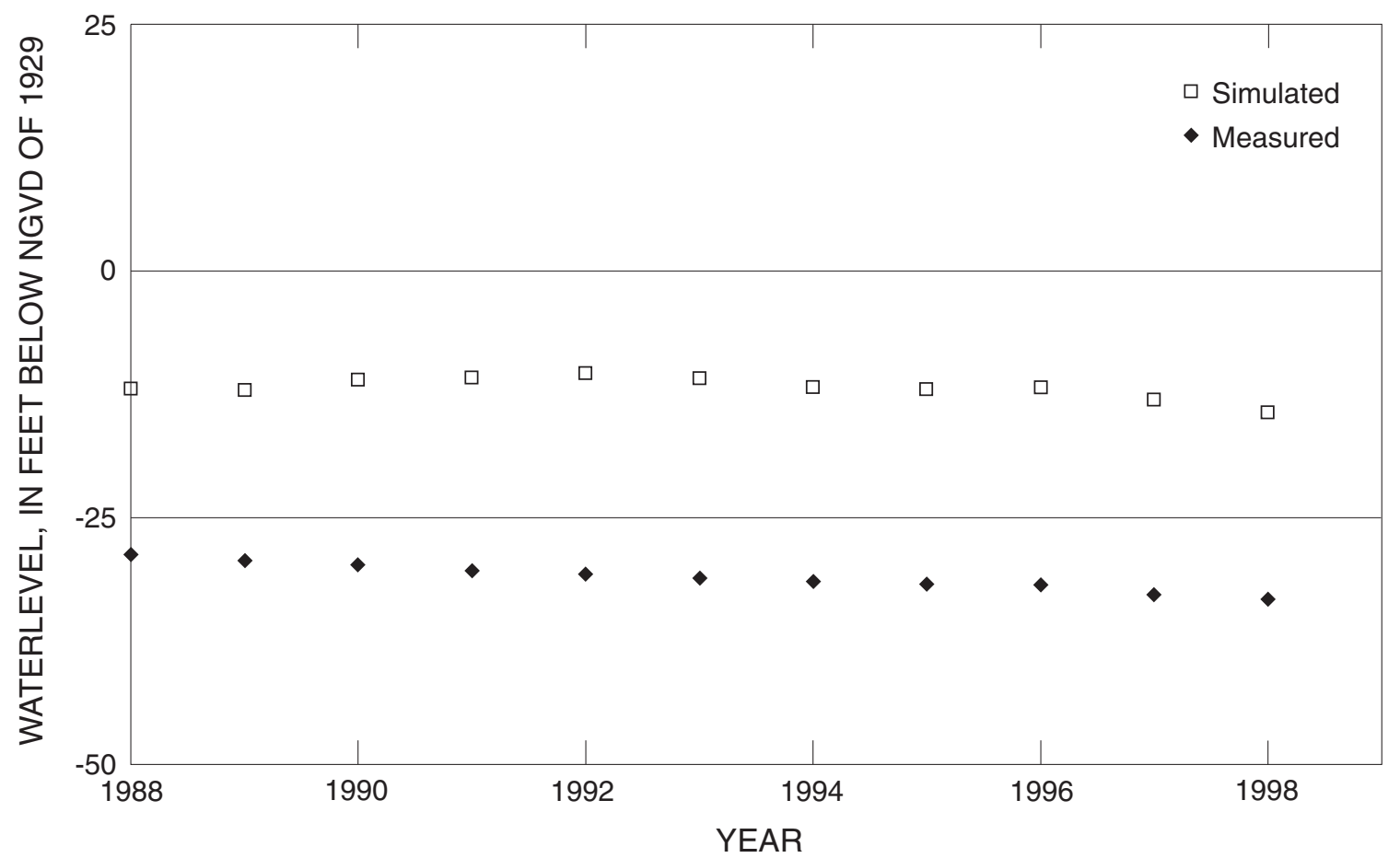

Figure 26. Simulated and measured water levels for well 1-834 screened in the Piney Point aquifer, New Jersey Coastal Plain, 1988-98. (Well location shown in fig. 22) 


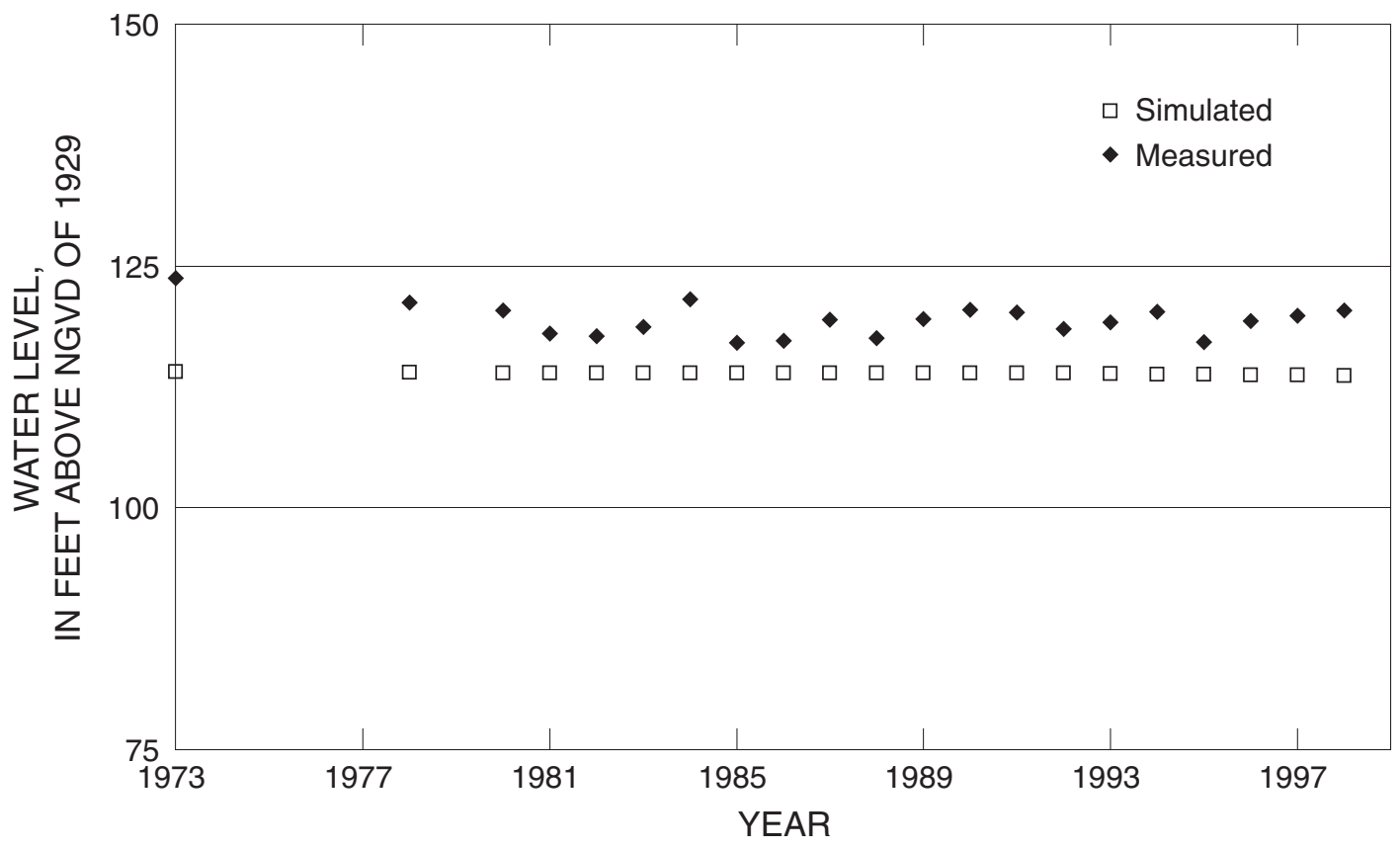

Figure 27. Simulated and measured wter levels for well 5-676 screened in the Piney Point aquifer, New Jersey Coastal Plain, 1973-98. (Well location shown in fig. 22)

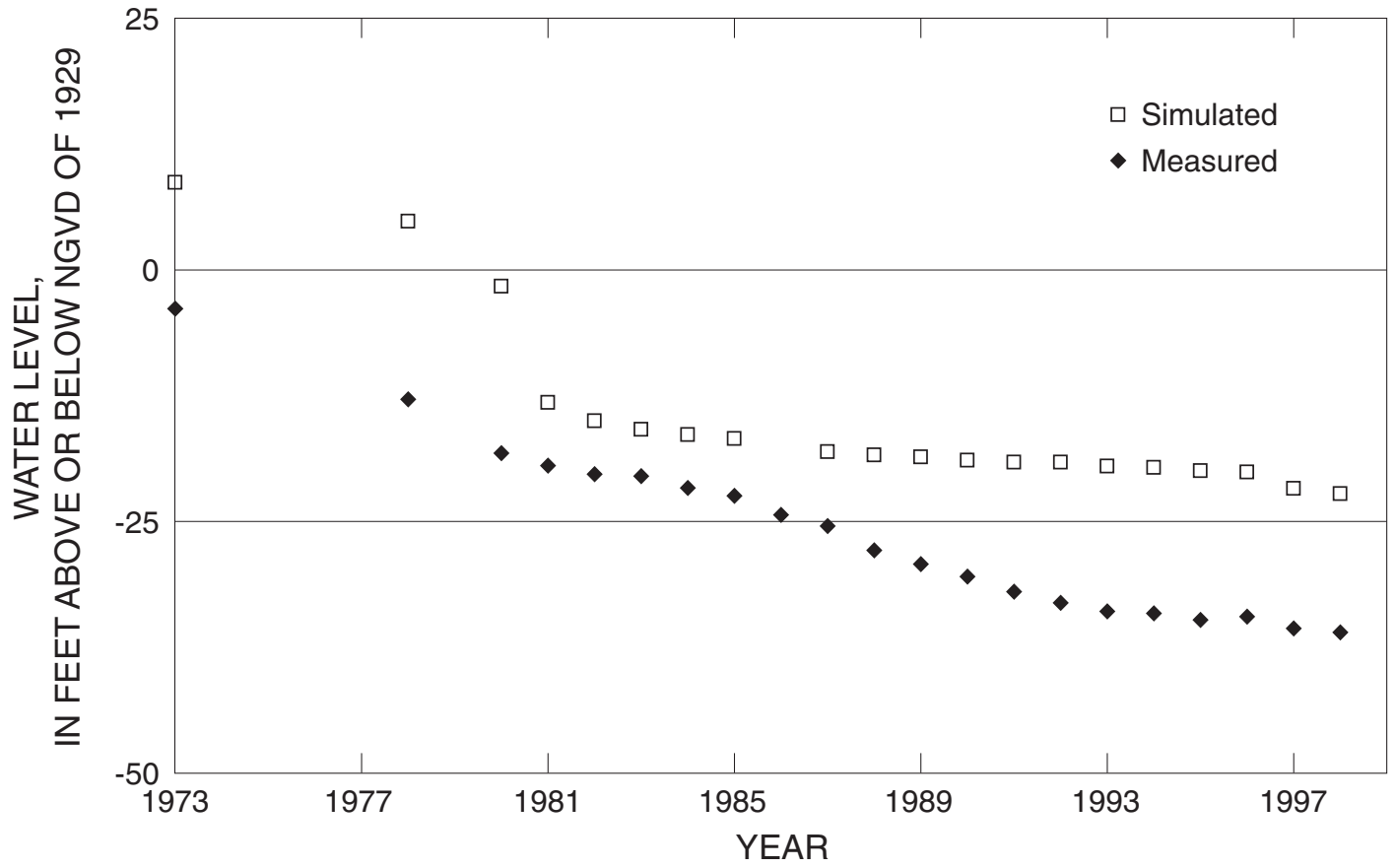

Figure 28. Simulated and measured water levels for well 11-96 screened in the Piney Point aquifer, New Jersey Coastal Plain, 1973-98. (Well location shown in fig. 22) 


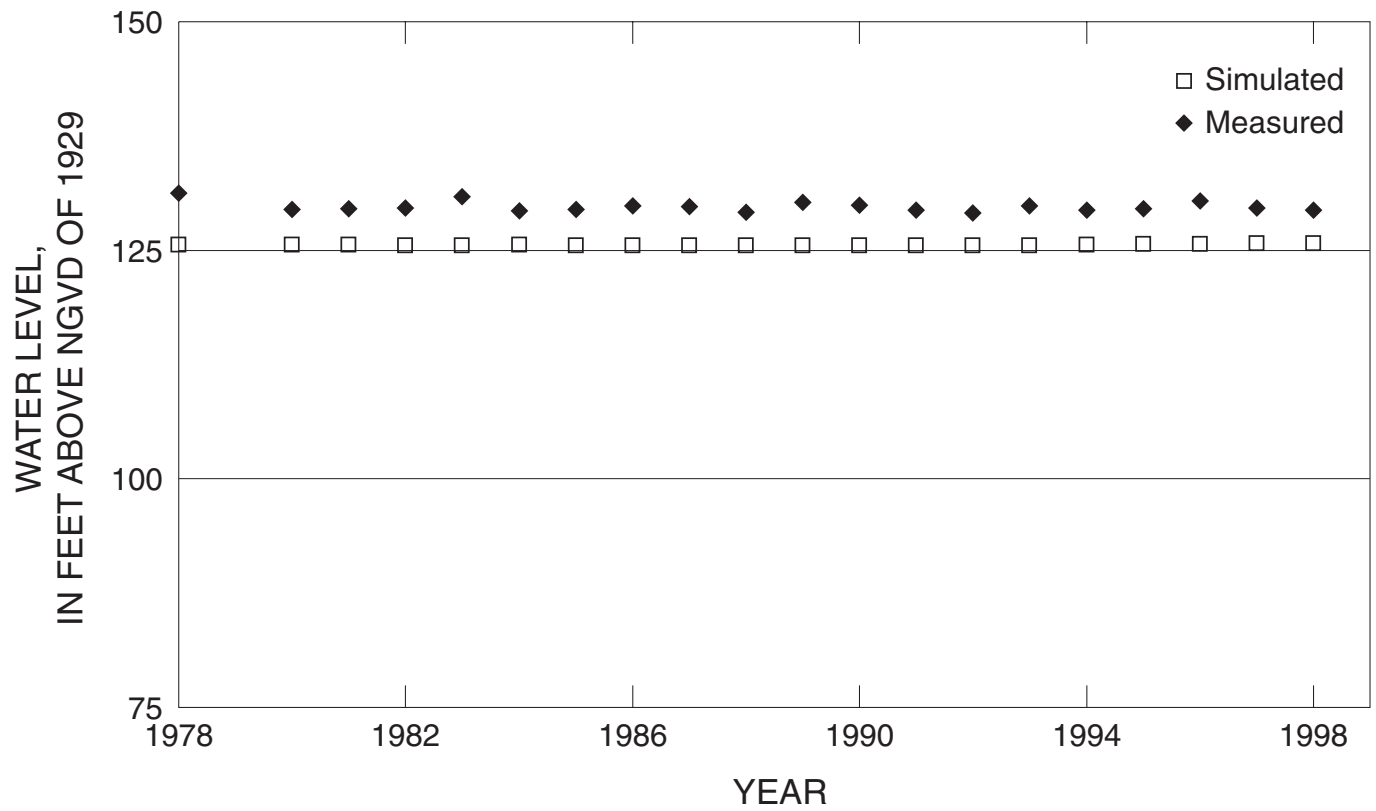

Figure 29. Simulated and measured water levels for well 29-139 screened in the Vincentown aquifer, New Jersey Coastal Plain, 1978-98. (Well location shown in fig. 22)

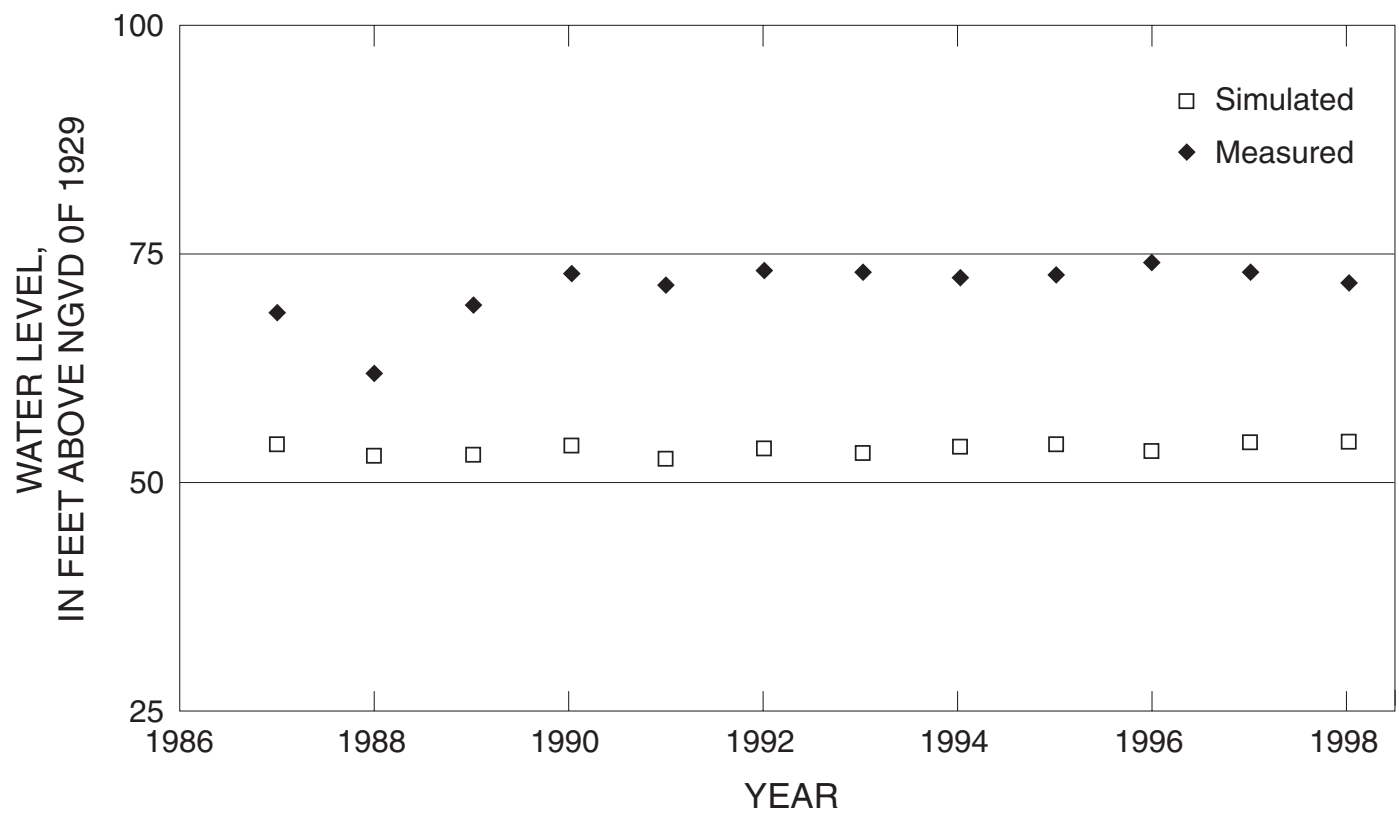

Figure 30. Simulated and measured water levels for well 25-636 screened in the Vincentown aquifer, New Jersey Coastal Plain, 1987-98. (Well location shown in fig. 22) 


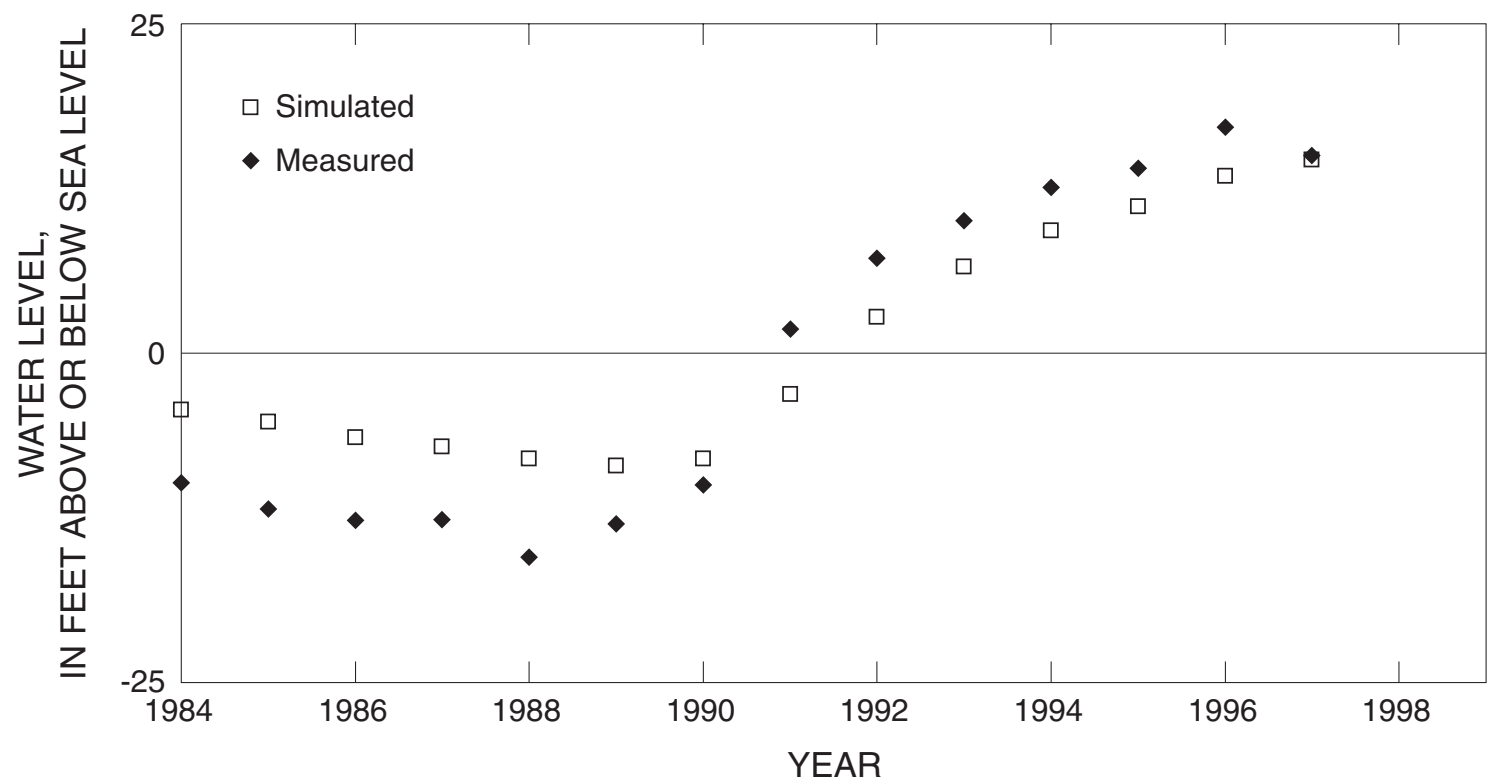

Figure 31. Simulated and measured water levels for well 25-353 screened in the Wenonah-Mount Laurel aquifer, New Jersey Coastal Plain, 1984-97. 


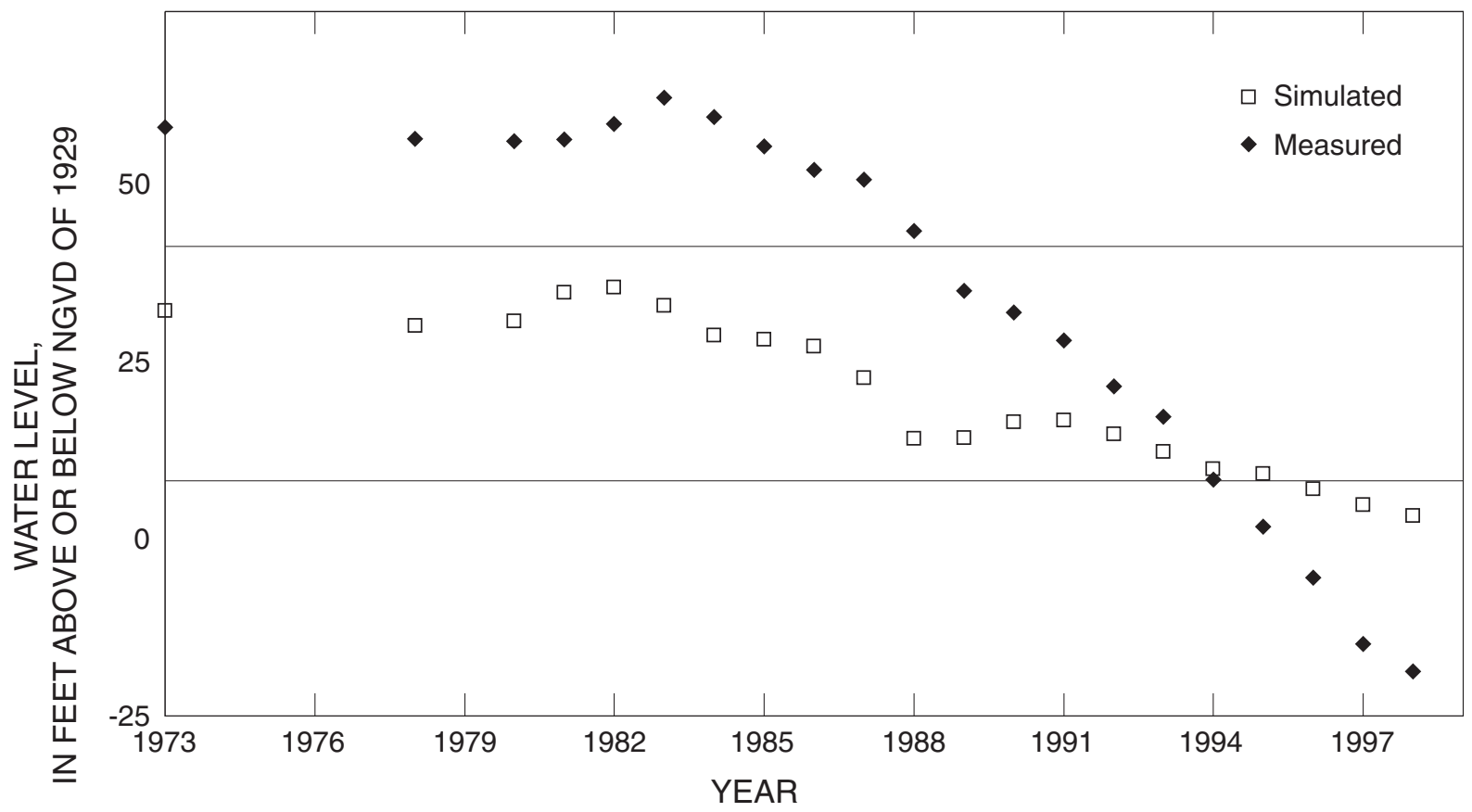

Figure 32. Simulated and measured water levels for well 7-478 screened in the Wenonah-Mount Laurel aquifer, New Jersey Coastal Plain, 1973-98. (Well location shown in fig. 22)

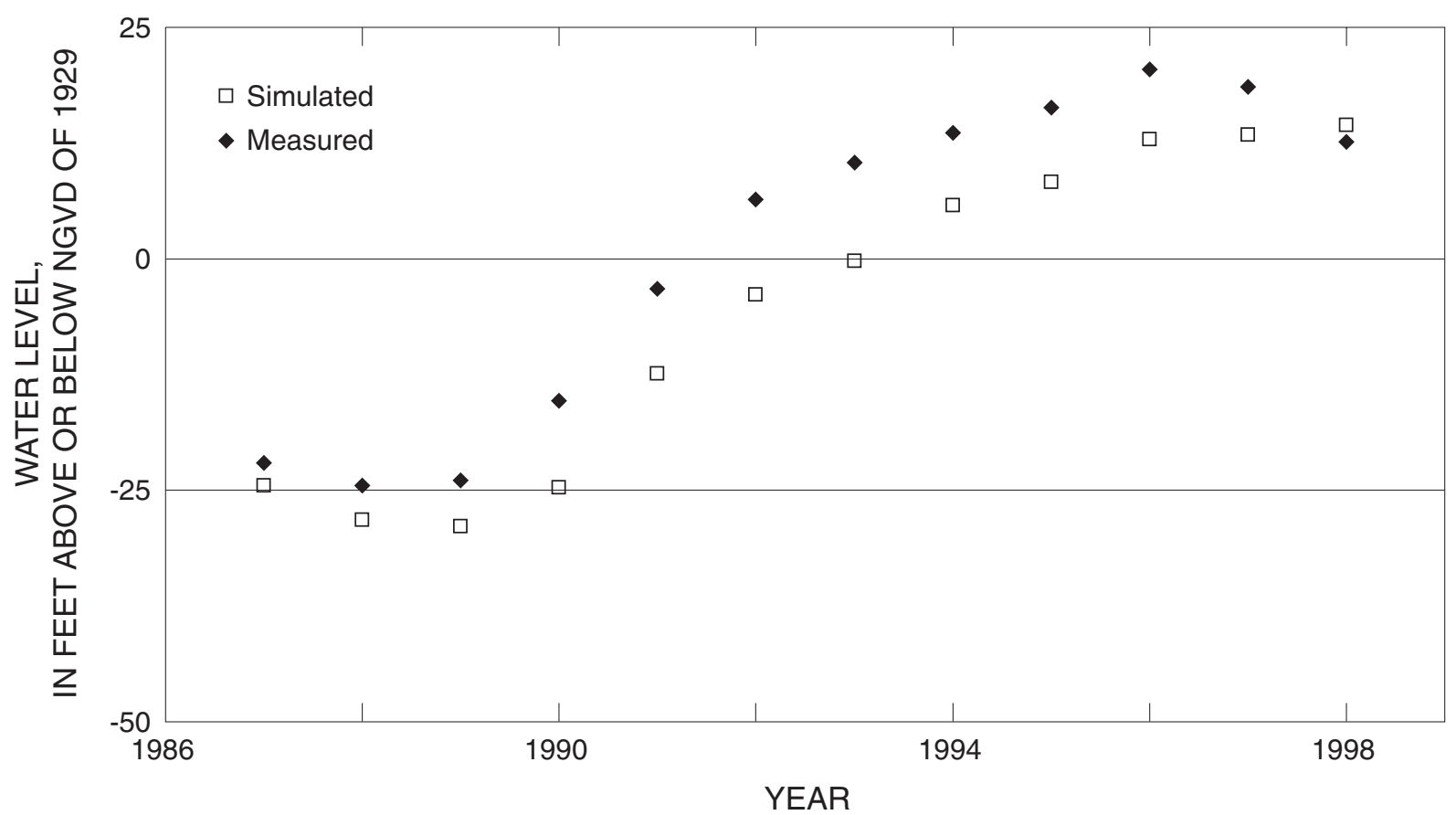

Figure 33. Simulated and measured water levels for well 25-637 screened in the Wenonah-Mount Laurel aquifer, New Jersey Coastal Plain, 1987-98. (Well location shown in fig. 22) 


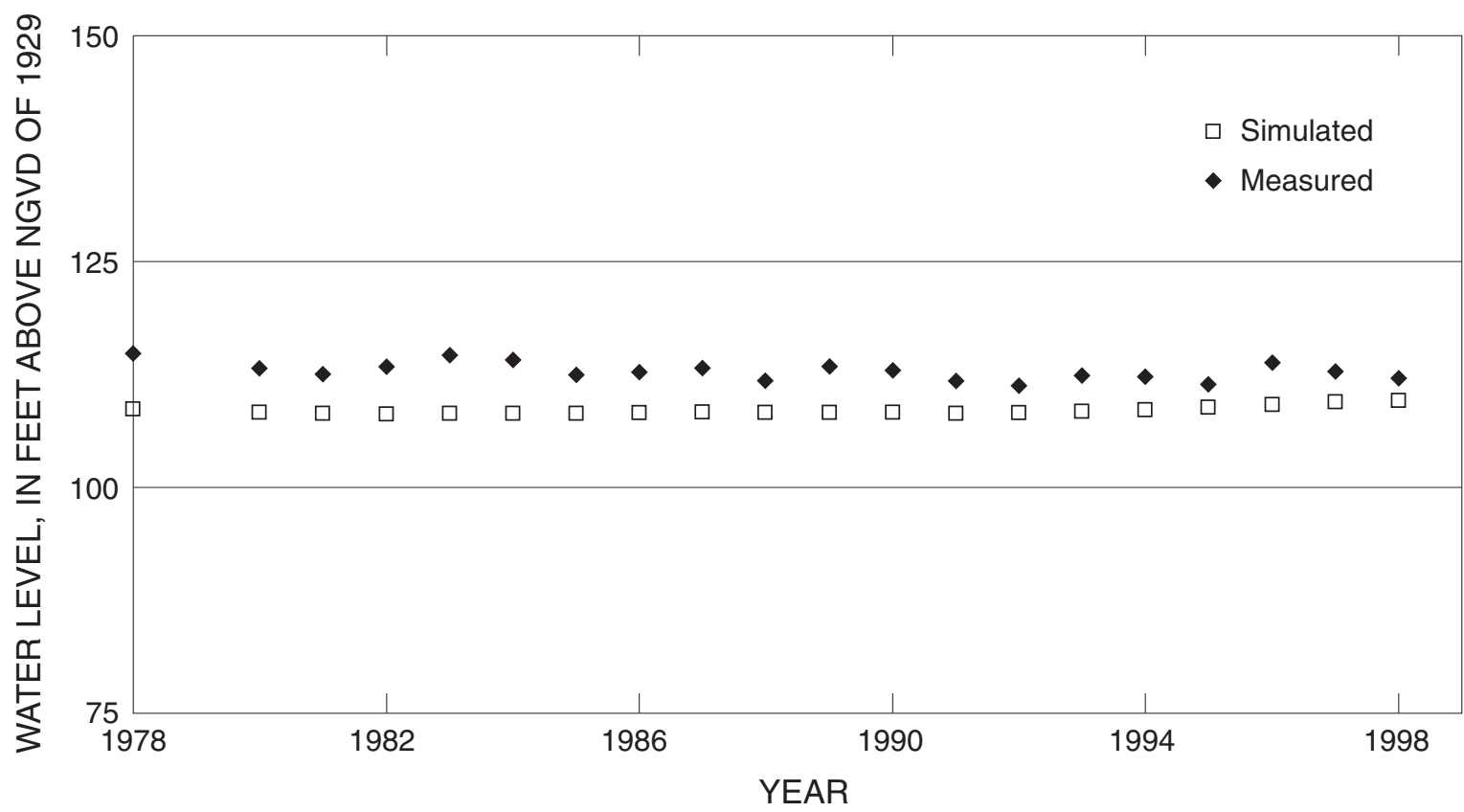

Figure 34. Simulated and measured water levels for well 29-140 screened in the Wenonah-Mount Laurel aquifer, New Jersey Coastal Plain, 1978-98. (Well location shown in fig. 22)

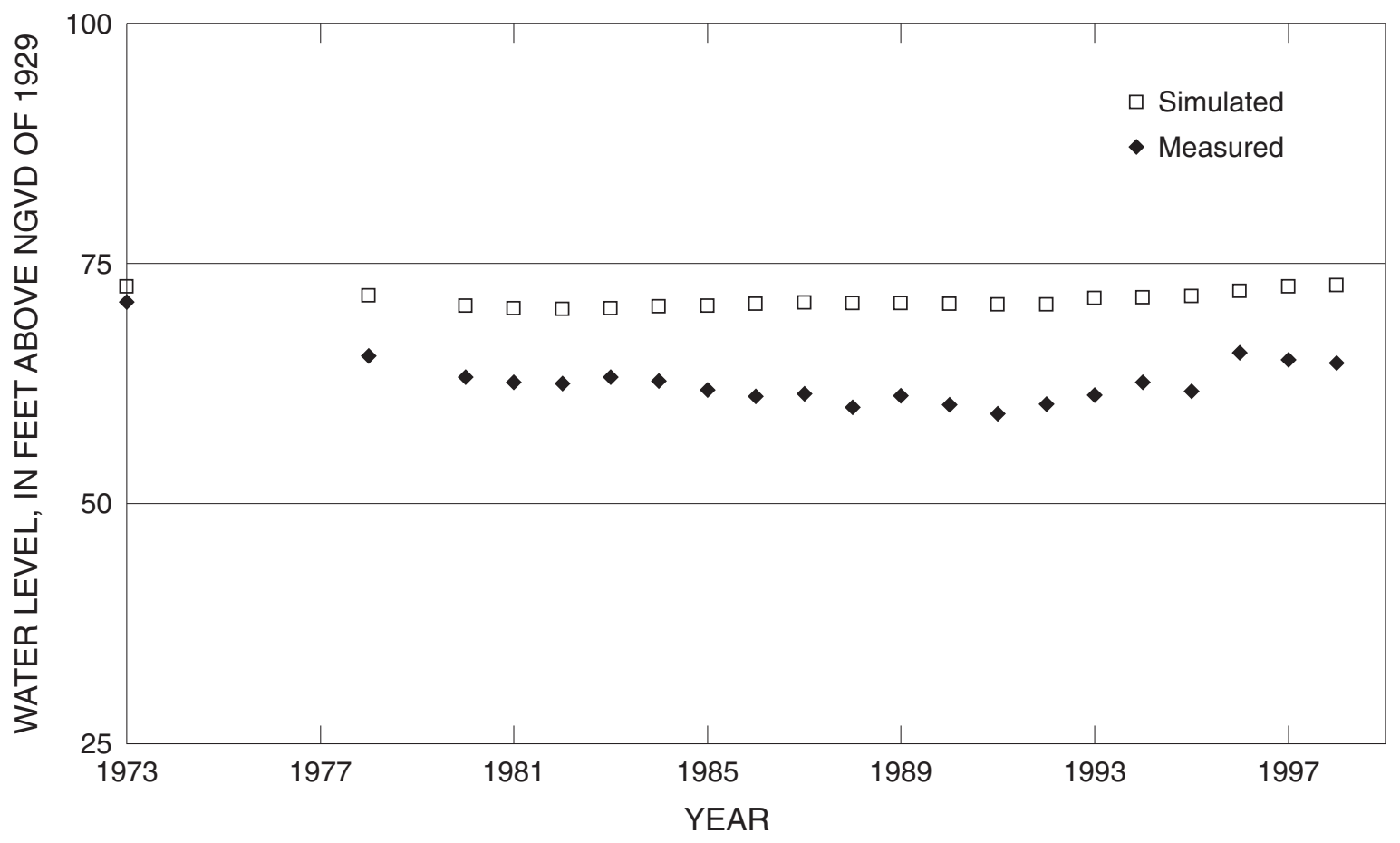

Figure 35. Simulated and measured water levels for well 29-138 screened in the Englishtown aquifer system, New Jersey Coastal Plain, 1973-98. (Well location shown in fig. 22) 


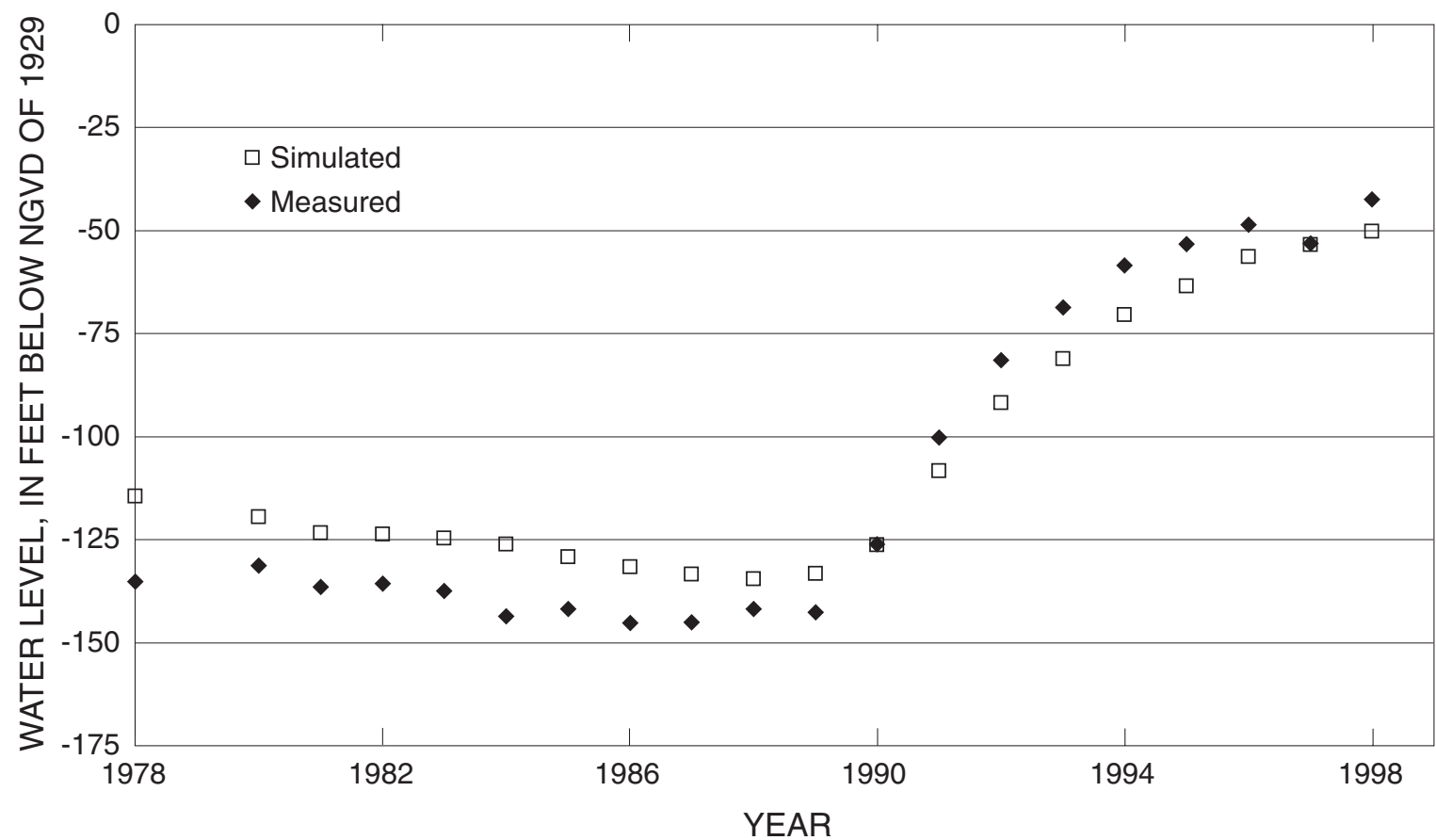

Figure 36. Simulated and measured water levels for well 25-429 screened in the Englishtown aquifer system, New Jersey Coastal Plain, 1978-98. (Well location shown in fig. 22)

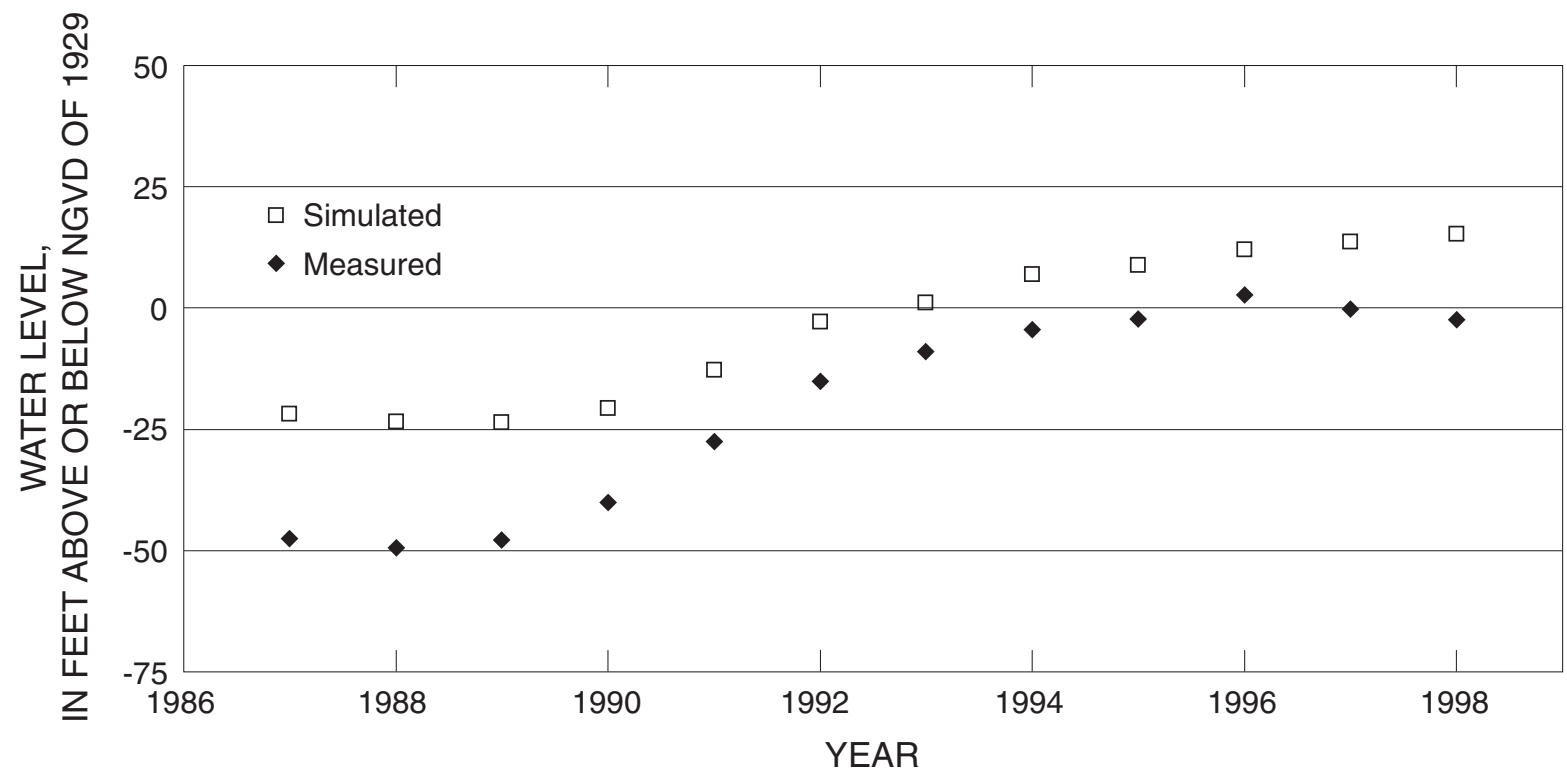

Figure 37. Simulated and measured water levels for well 25-638 screened in the Englishtown aquifer system, New Jersey Coastal Plain, 1987-98. (Well location shown in fig. 22) 


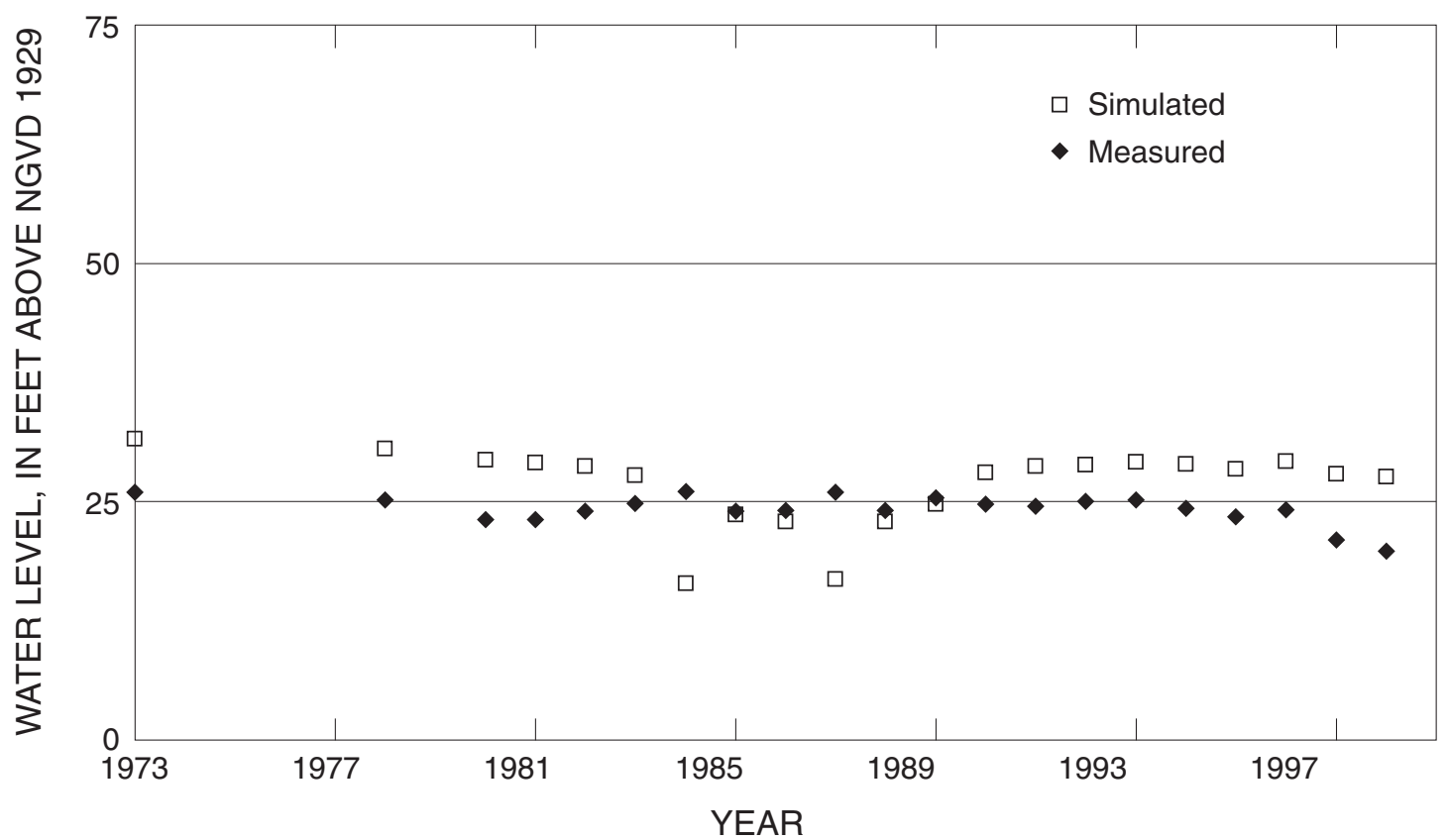

Figure 38. Simulated and measured water levels for well 5-259 screened in the Englishtown aqifer system, New Jersey Coastal Plain, 1973-98. (Well location shown in fig. 22)

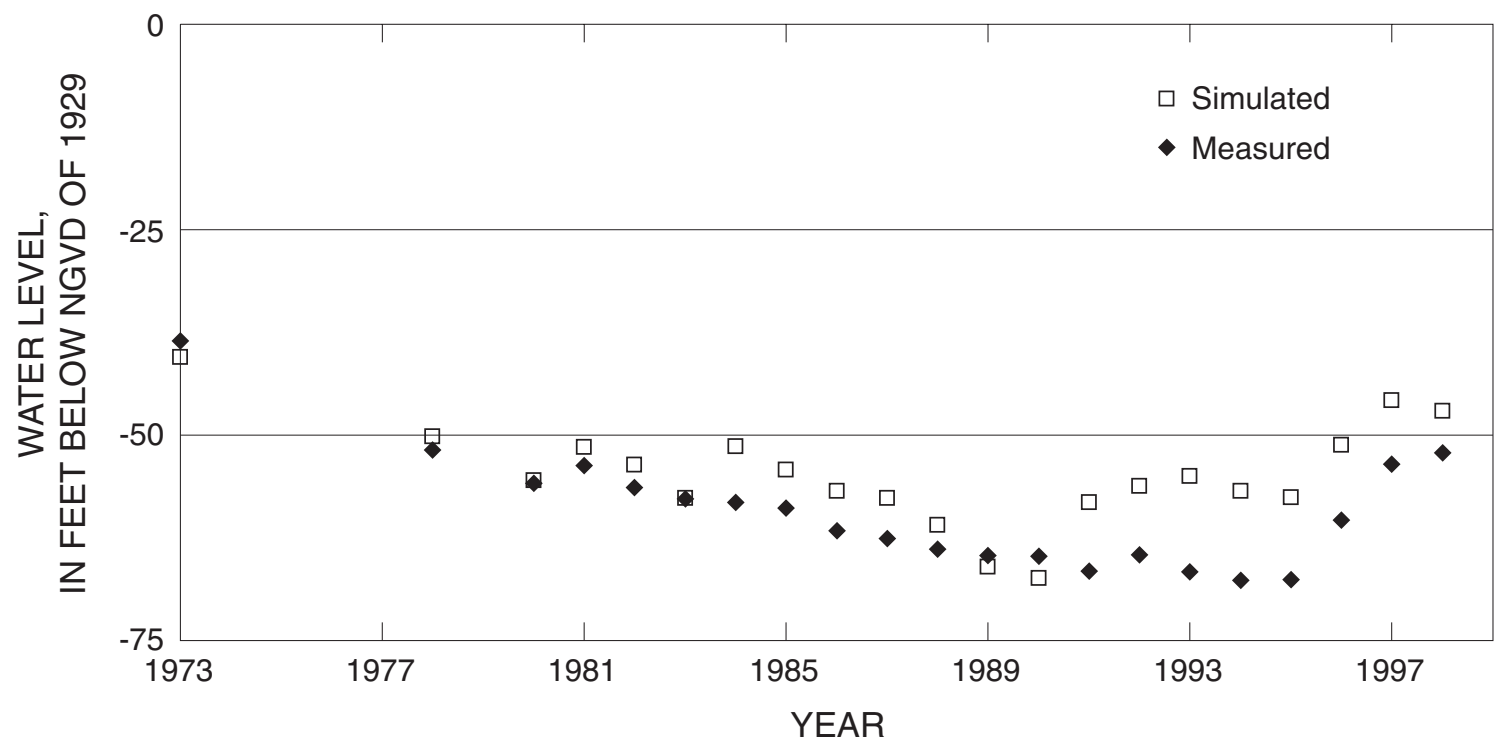

Figure 39. Simulated and measured water levels for well 5-258 screened in the Upper Potomac-RaritanMagothy aquifer, New Jersey Coastal Plain, 1973-98. (Well location shown in fig. 22) 


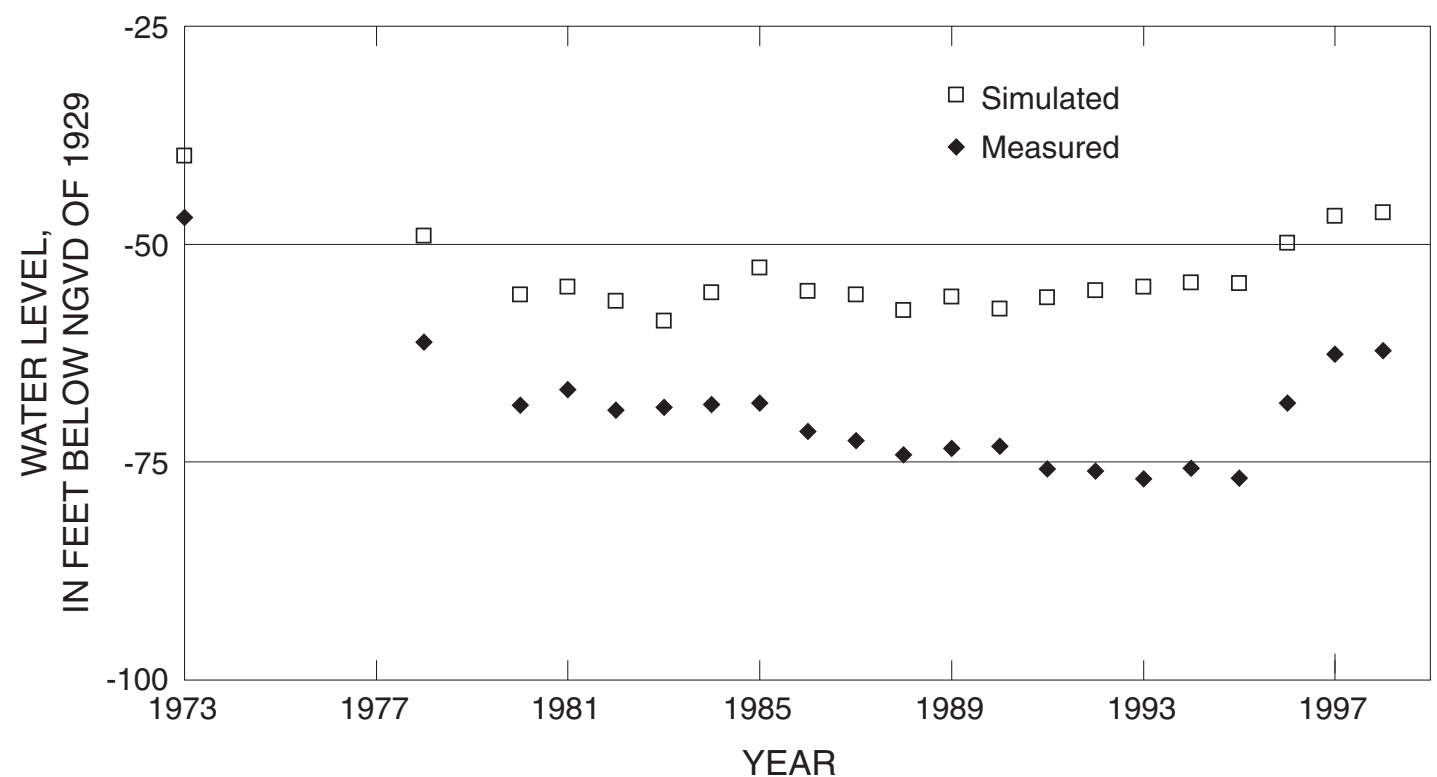

Figure 40. Simulated and measured water levels for well 7-477 screened in the Upper Potomac-RaritanMagothy aquifer, New Jersey Coastal Plain, 1973-98. (Well location shown in fig. 22)

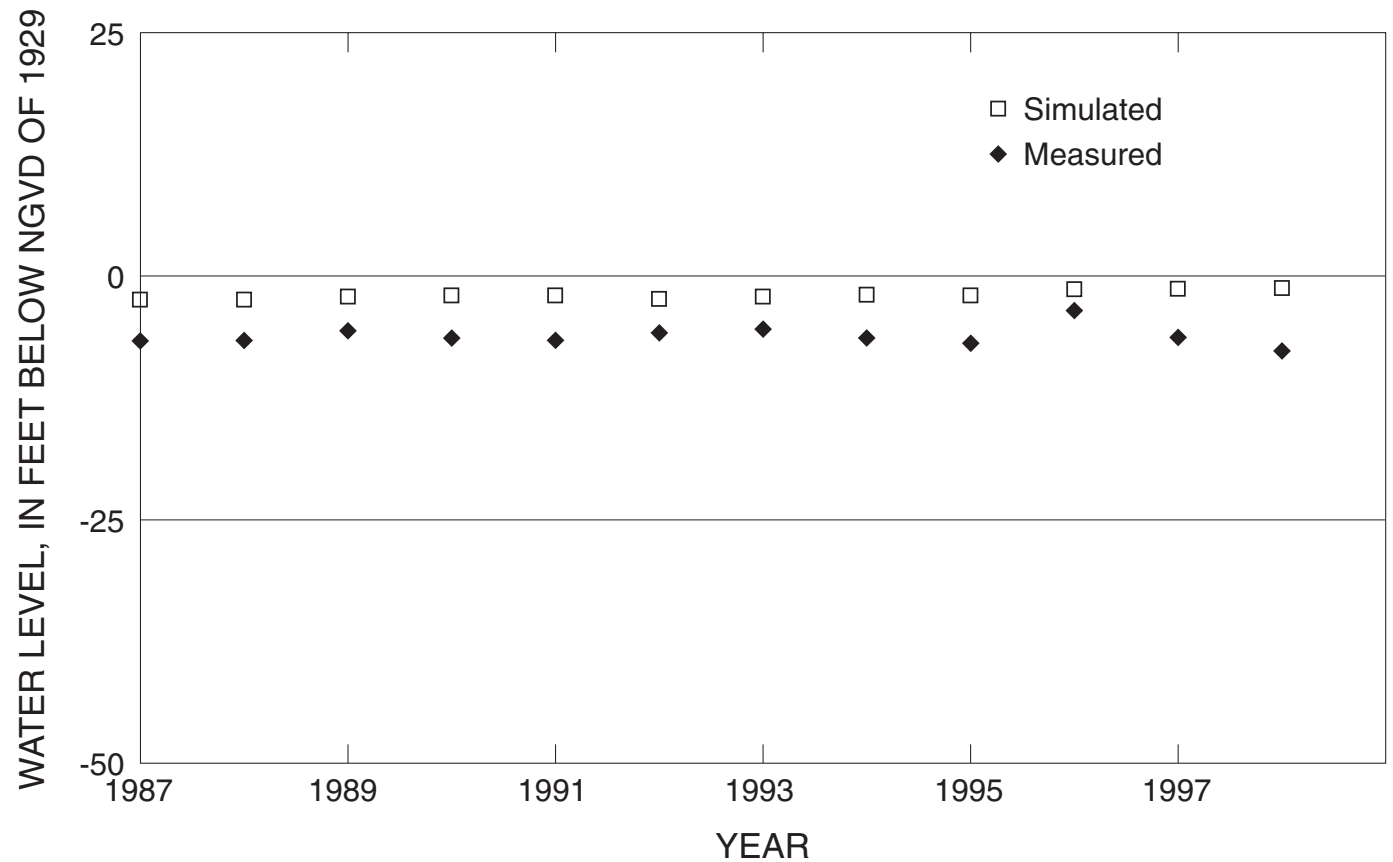

Figure 41. Simulated and measured water levels for well 15-728 screened in the Upper Potomac-RaritanMagothy aquifer, New Jersey Coastal Plain, 1987-98. (Well location shown in fig. 22) 


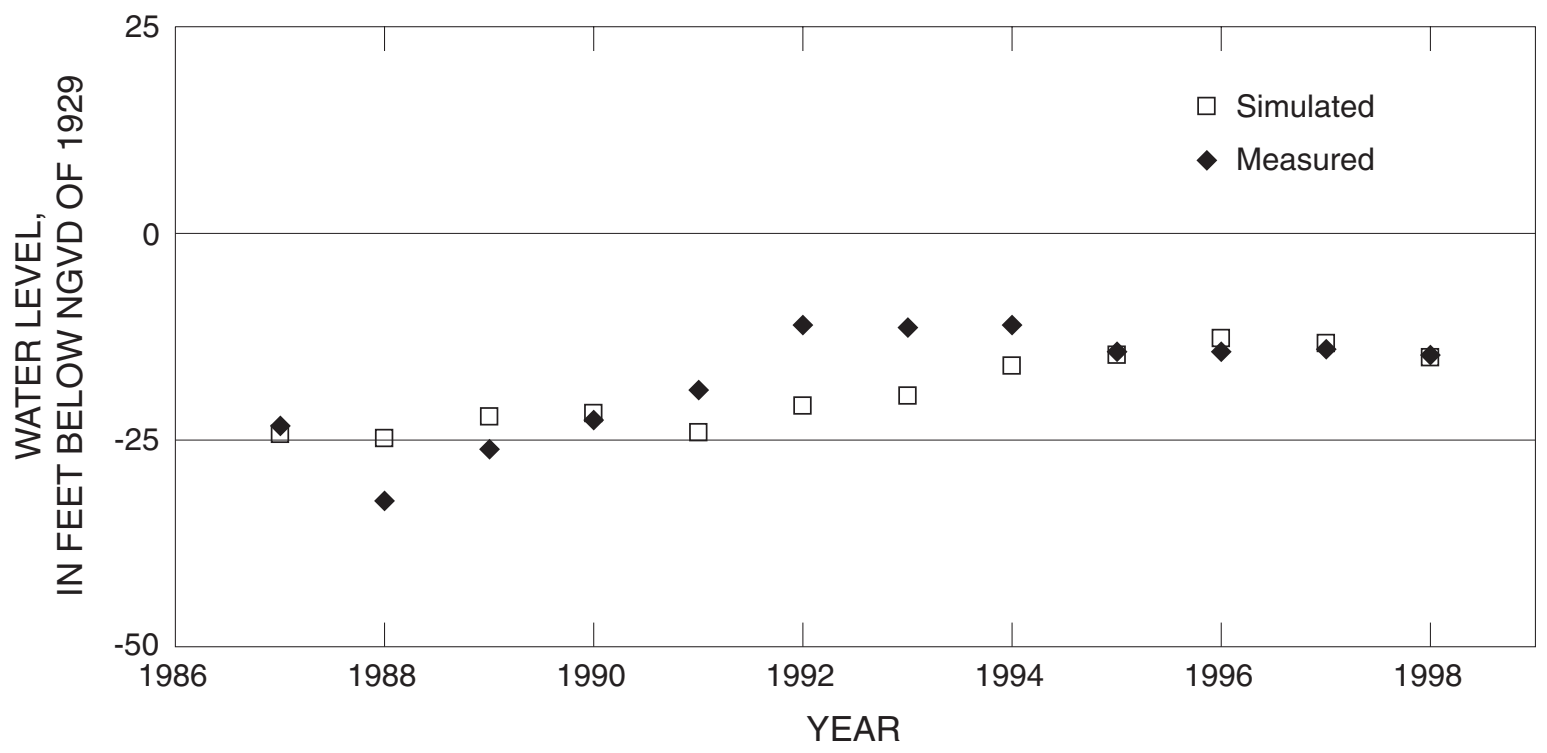

Figure 42. Simulated and measured water levels for well 25-639 screened in the Upper Potomac-Raritan-Magothy aquifer, New Jersey Coastal Plain, 1987-98. (Well location show in fig. 22)

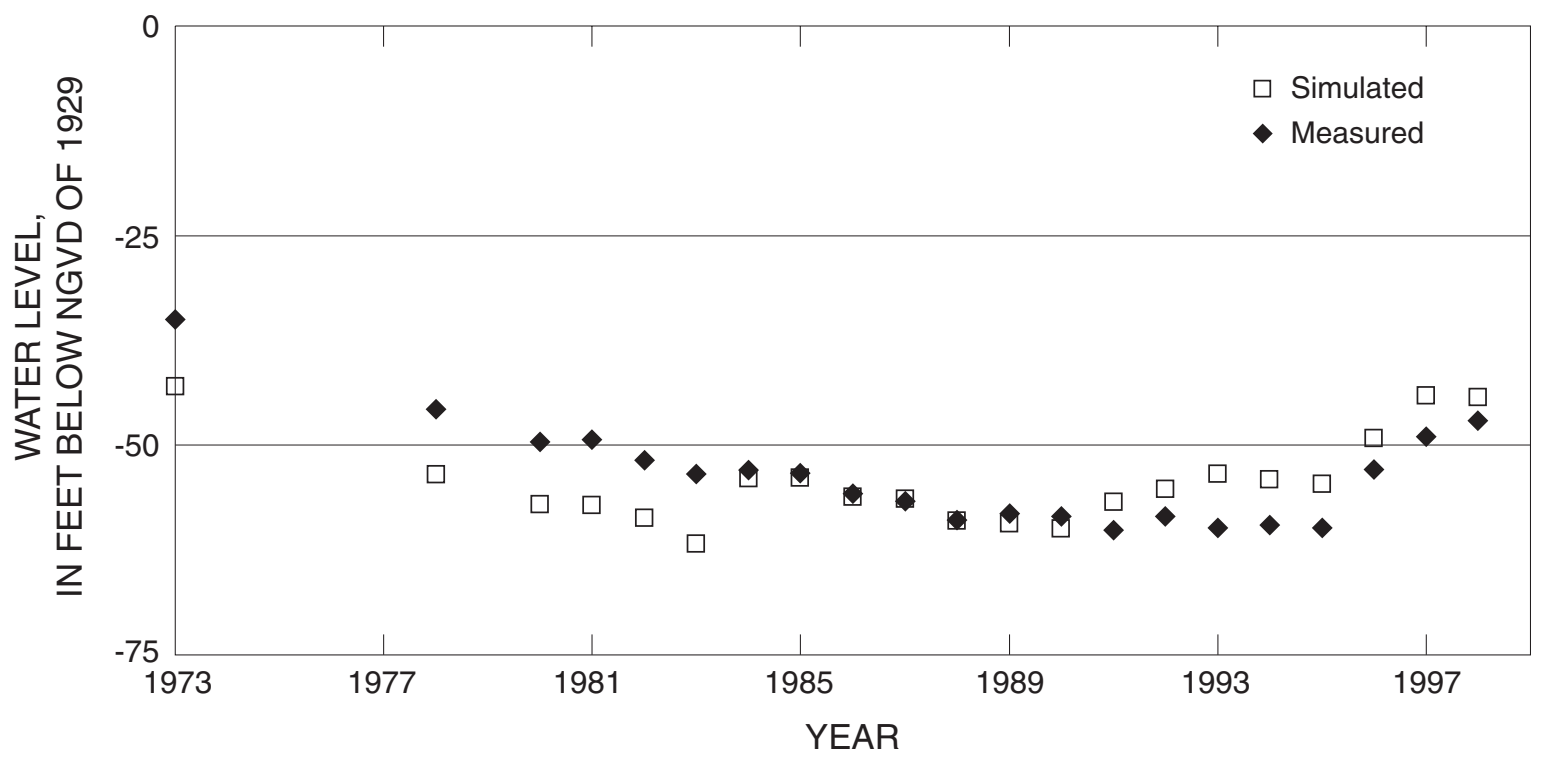

Figure 43. Simulated and measured water levels for well 5-261 screened in the Middle Potomac-Raritan-Magothy aquifer, New Jersey Coastal Plain, 1973-98. (Well location shown in fig. 22) 


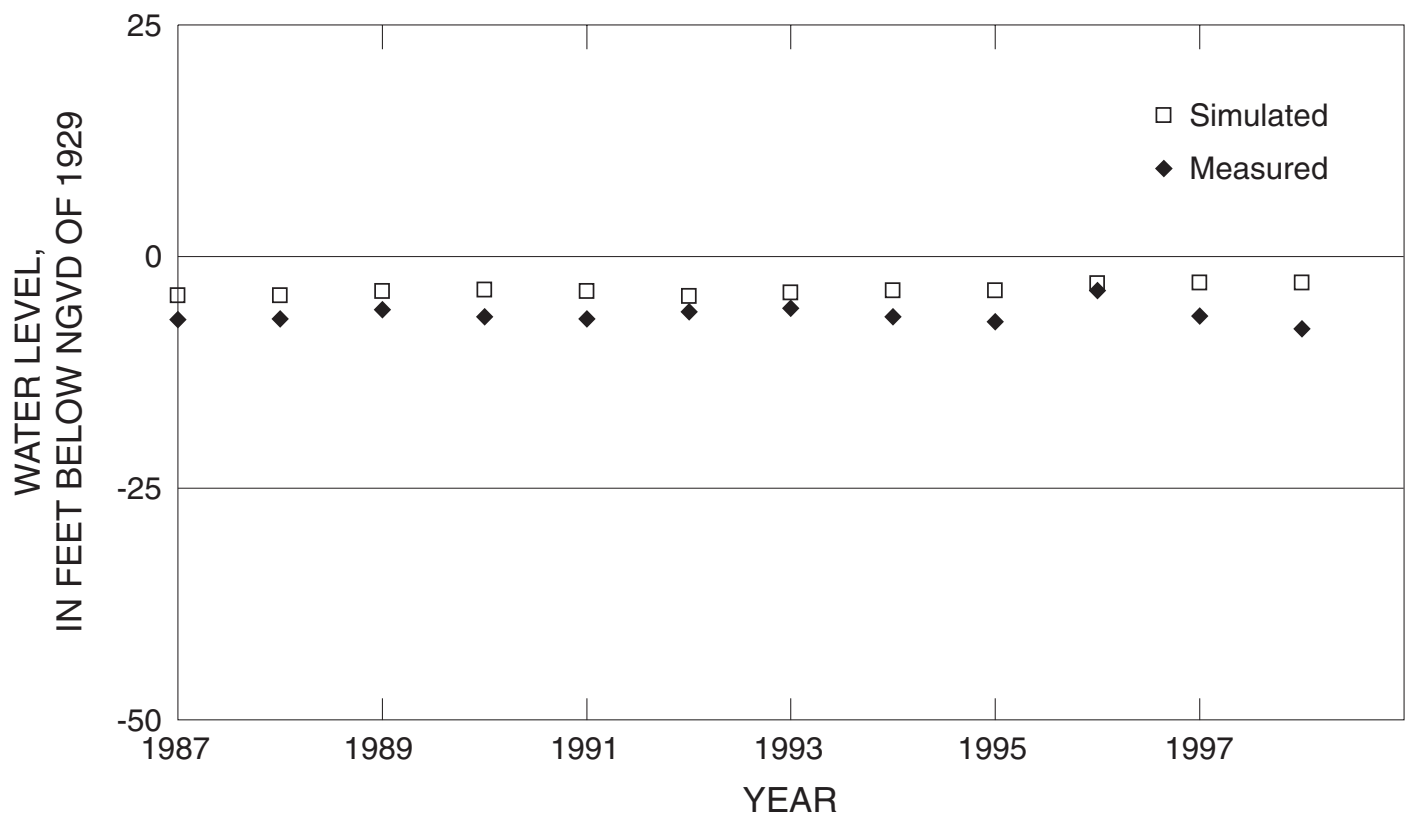

Figure 44. Simulated and measured water levels for well 15-713 screened in the Middle Potomac-RaritanMagothy aquifer, New Jersey Coastal Plain, 1987-98. (Well location shown in fig. 22)

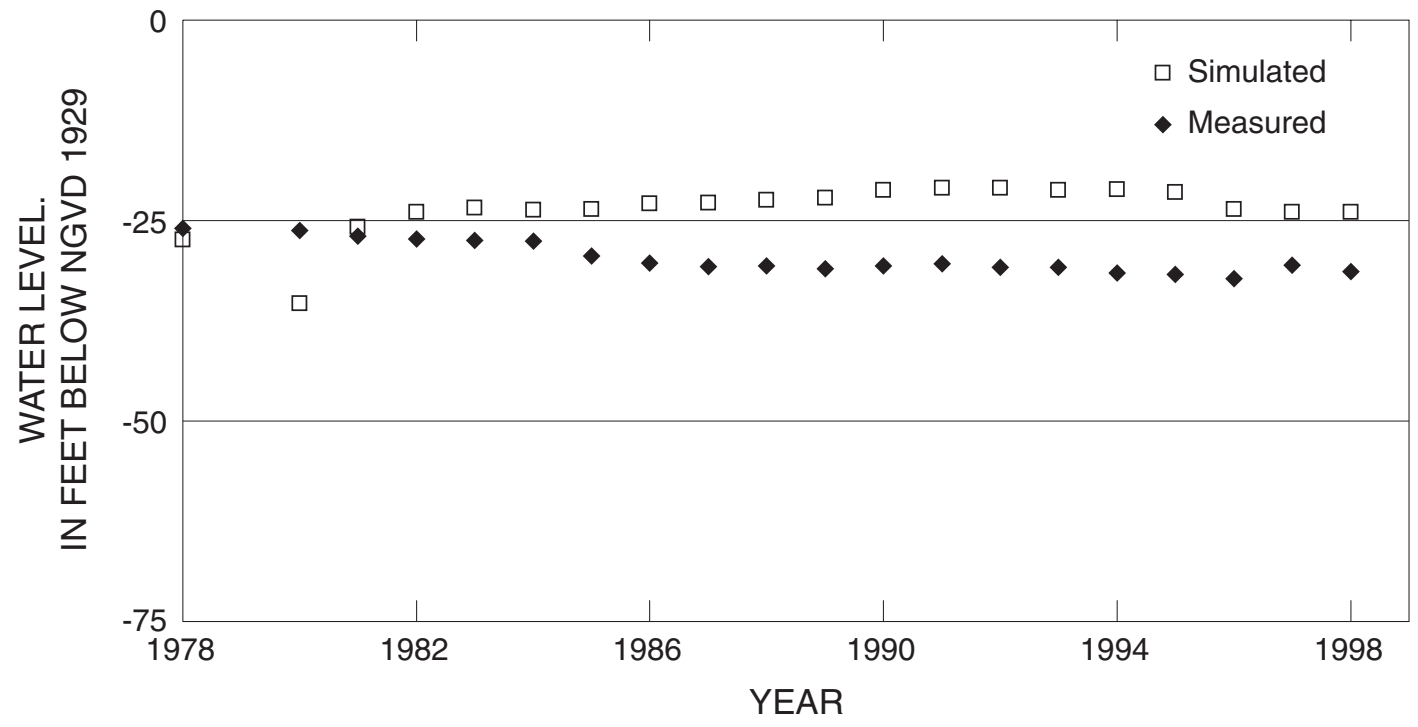

Figure 45. Simulated and measured wter levels for well 33-251 screened in the Middle Potomac-RaritanMagothy aquifer, New Jersey Coastal Plain, 1978-98. (Well location shown in fig. 22) 


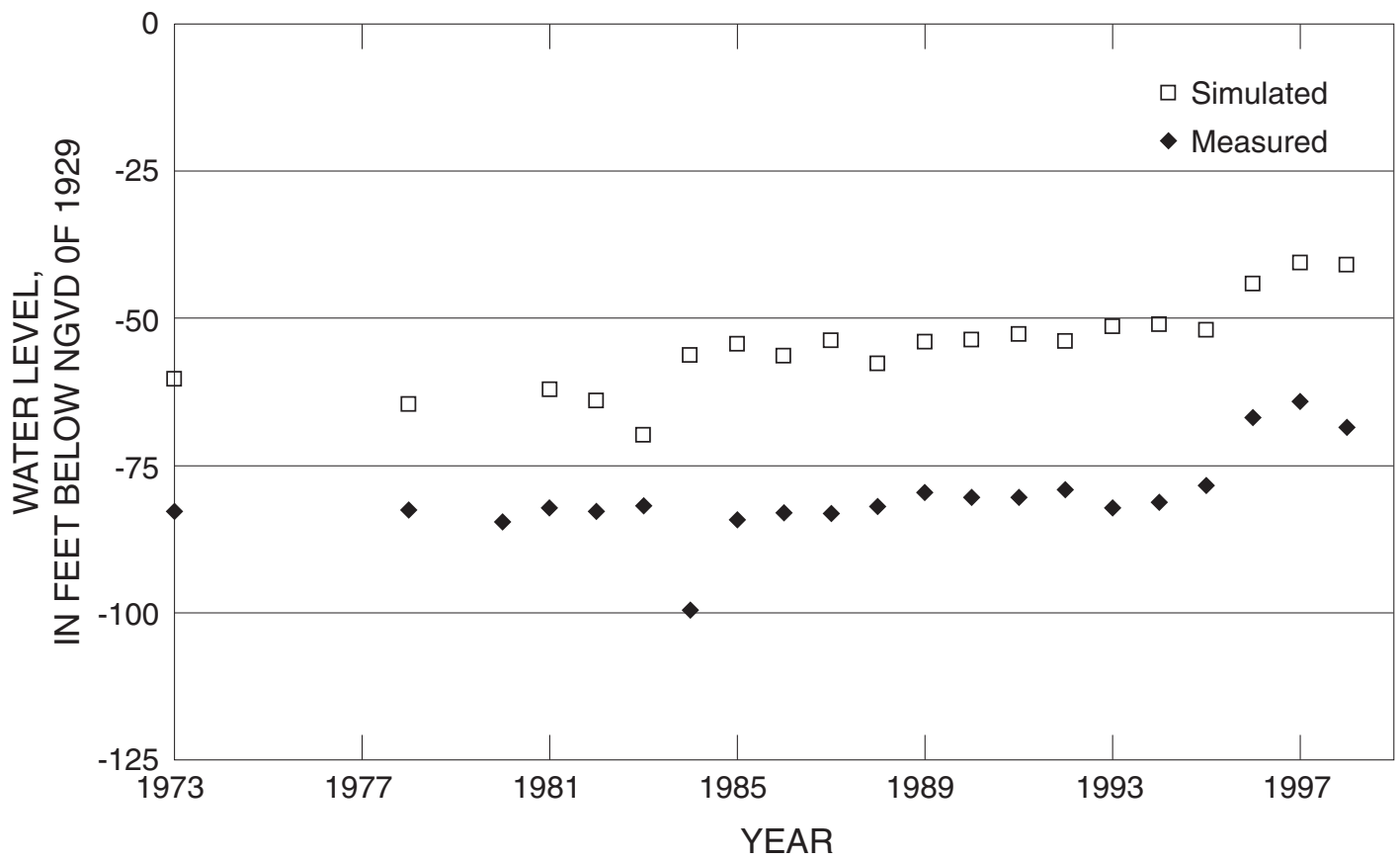

Figure 46. Simulated and measured water levels for well 7-283 screened in the Lower PotomacRaritan-Magothy aquifer, New Jersey Coastal Plain, 1973-98. (Well location shown in fig. 22)

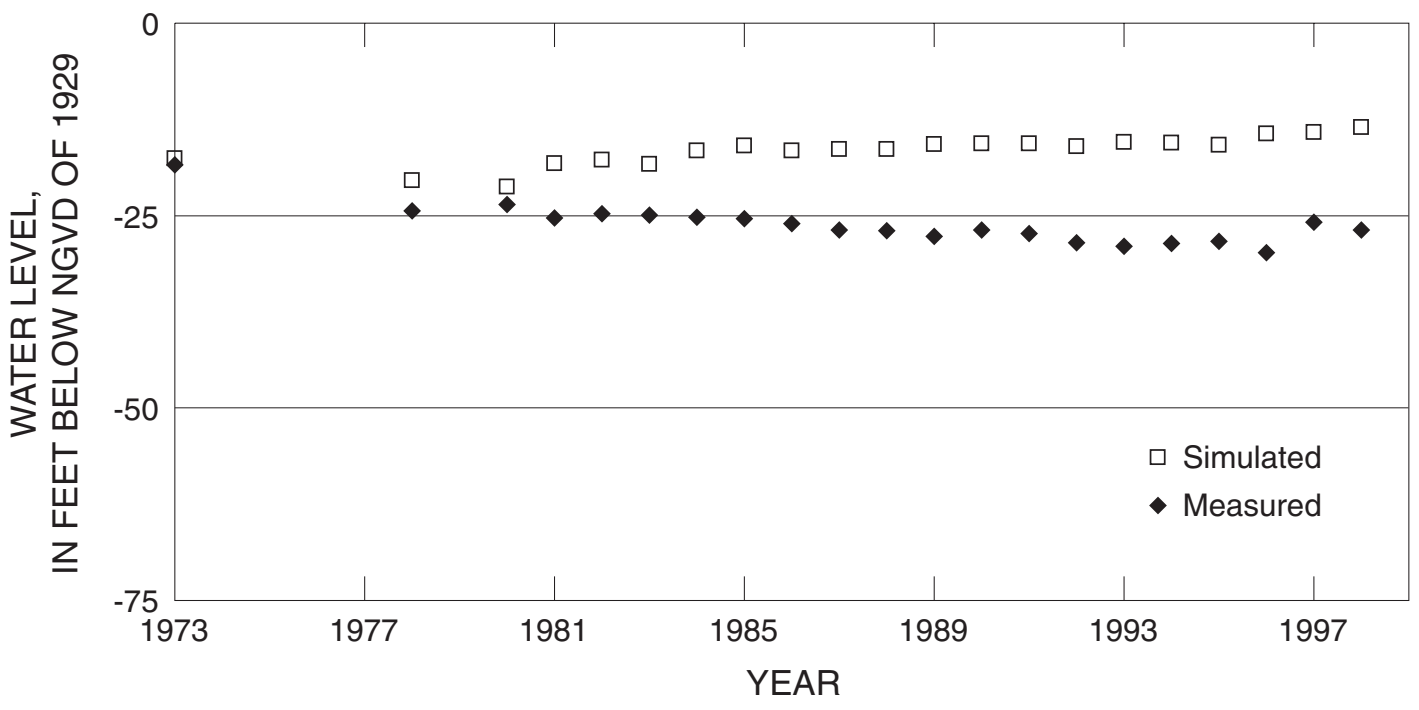

Figure 47. Simulated and measured water levels for well 33-187 screened in the Lower PotomacRaritan-Magothy aquifer, New Jersey Coastal Plain, 1973-98. (Well location shown in fig. 22) 


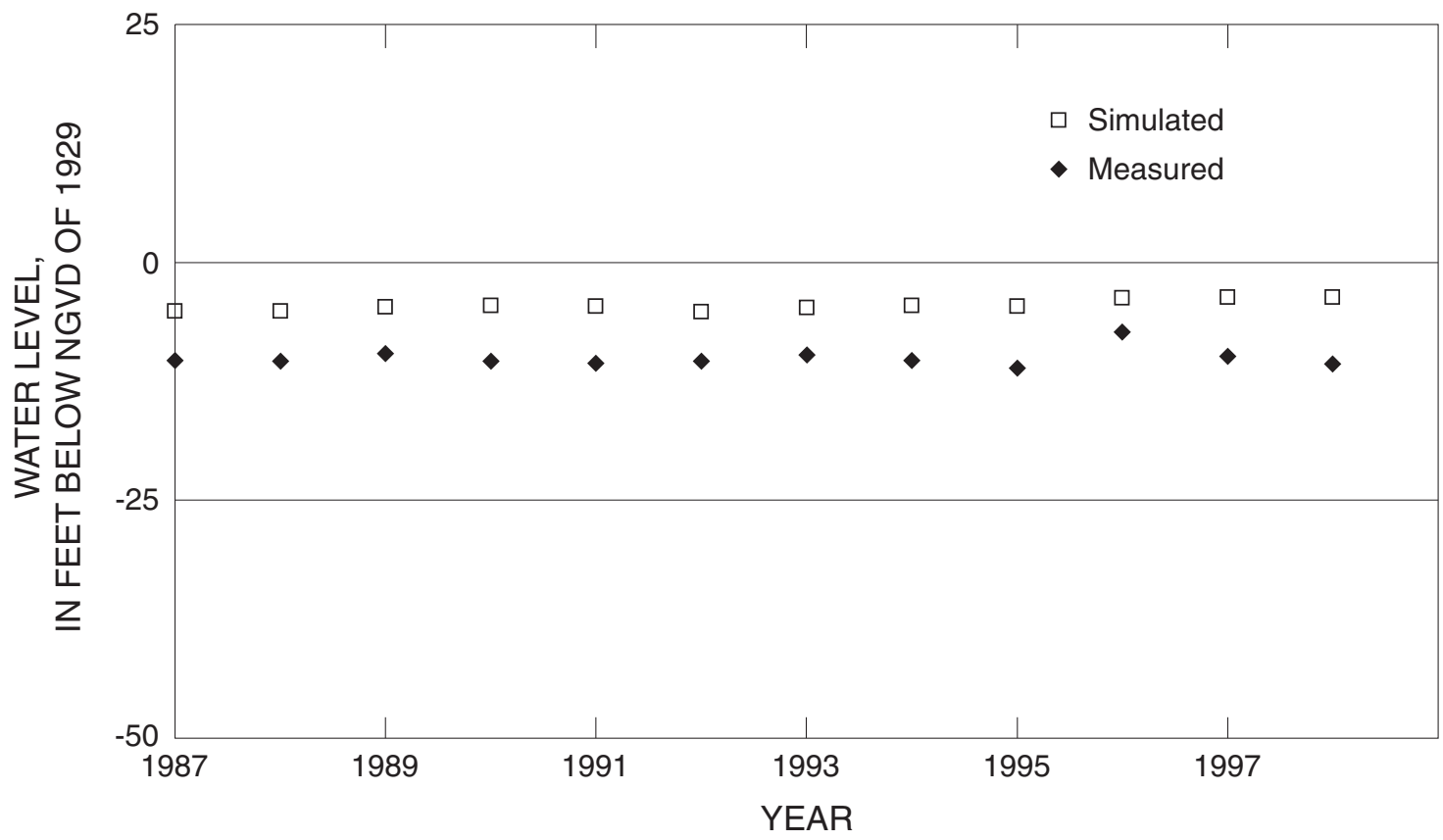

Figure 48. Simulated and measured water levels for well 15-712 screened in the Lower Potomac-Raritan-Magothy aquifer, New Jersey Coastal Pain, 1987-98. (Well location shown in fig. 22)

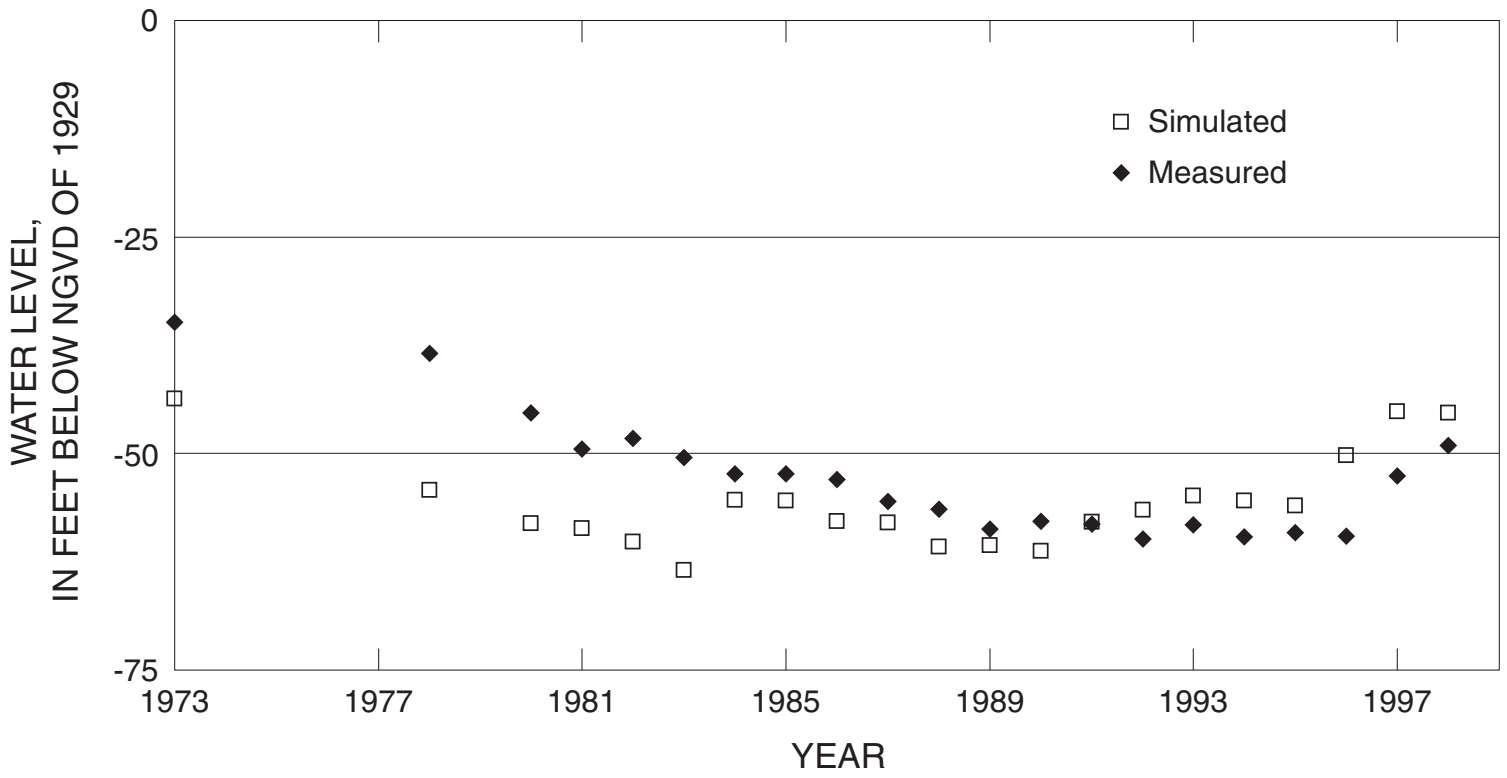

Figure 49. Simulated and measured water levels for well 5-262 screened in the Lower Potomac-Raritan-Magothy aquifer, New Jersey Coastal Plain, 1973-98. (Well location shown in fig. 22) 
Table 4. Simulated and estimated base flows at five continuous-record streamflow-gaging stations in the New Jersey Coastal Plain

\begin{tabular}{|c|c|c|c|c|c|c|c|}
\hline \multicolumn{2}{|c|}{$\begin{array}{c}\text { U.S. Geological Survey } \\
\text { Streamflow-gaging station }\end{array}$} & \multirow[b]{2}{*}{ Reference } & \multirow[b]{2}{*}{$\begin{array}{l}\text { Basin } \\
\text { drainage } \\
\text { area, } \\
\text { (square } \\
\text { miles) }\end{array}$} & \multirow[b]{2}{*}{$\begin{array}{l}\text { Period of } \\
\text { record for } \\
\text { calculated } \\
\text { mean base } \\
\text { flow }\end{array}$} & \multirow[b]{2}{*}{$\begin{array}{l}\text { Calculated } \\
\text { mean base } \\
\text { flow, } \\
\text { (cubic feet per } \\
\text { second) }\end{array}$} & \multirow[b]{2}{*}{$\begin{array}{c}\text { Simulated } \\
\text { base flow, } \\
\text { (cubic feet } \\
\text { per second) }\end{array}$} & \multirow[b]{2}{*}{$\begin{array}{l}\text { Difference, } \\
\text { in percent }\end{array}$} \\
\hline Number & Name & & & & & & \\
\hline 01408500 & $\begin{array}{l}\text { Toms River } \\
\text { near Toms } \\
\text { River, N.J. }\end{array}$ & $\begin{array}{l}\text { Watt and } \\
\text { others, } 1994, \\
\text { plate } 3\end{array}$ & 123 & $1928-96$ & 184.29 & 164.06 & 11 \\
\hline 01467000 & $\begin{array}{l}\text { North Branch } \\
\text { Rancocas Creek } \\
\text { at Pemberton, } \\
\text { N.J. }\end{array}$ & $\begin{array}{l}\text { Watt and } \\
\text { others, 2003, } \\
\text { plate } 3\end{array}$ & 118 & $1921-96$ & 140.9 & 144.87 & 3 \\
\hline 01465850 & $\begin{array}{l}\text { South Branch } \\
\text { Rancocas Creek } \\
\text { at Vincentown, } \\
\text { N.J. }\end{array}$ & $\begin{array}{l}\text { Modica, } \\
\text { 1996, table } 3\end{array}$ & 64.5 & $1962-76$ & 69.33 & 80.77 & 14 \\
\hline 01477120 & $\begin{array}{l}\text { Raccoon Creek } \\
\text { near Swedes- } \\
\text { boro, N.J. }\end{array}$ & $\begin{array}{l}\text { Johnson and } \\
\text { Charles, } \\
\text { 1997, plate } 3\end{array}$ & 26.9 & $1966-92$ & 30 & 20.85 & 31 \\
\hline 01482500 & $\begin{array}{l}\text { Salem River } \\
\text { near Wood- } \\
\text { stown, N.J. }\end{array}$ & $\begin{array}{l}\text { Johnson and } \\
\text { Charles, } \\
\text { 1997, plate } 3\end{array}$ & 14.6 & $1940-90$ & 12 & 16.37 & 27 \\
\hline
\end{tabular}




\section{Summary}

As part of an ongoing program to maintain ground-waterflow models constructed in New Jersey, the U.S. Geological Survey (USGS), in cooperation with New Jersey Department of Environmental Protection (NJDEP), developed a standardized procedure to archive the models and revise selected models by incorporating recent data, such as withdrawal data and simulation techniques. The Regional Aquifer System Analysis finitedifference numerical model of flow in the New Jersey Coastal Plain sediments (Martin, 1998) was revised by (1) rediscretizing the model parameters with a finer cell size, (2) using a spatially variable recharge rate that is based on rates determined in studies conducted since the model was initially developed in 1981, and (3) using recent ground-water withdrawal data for 1982-98.

The revised New Jersey Coastal Plain model can be used as a tool to evaluate the regional effect on water levels of changes in ground-water withdrawals. The model can aid in reevaluating water-management strategies in the New Jersey Coastal Plain.

The revised model was calibrated by trail-and-error adjustment of the storage coefficient, vertical leakance, streambed conductance, lateral-boundary fluxes, and recharge rates. Recharge rates were adjusted in areas where no previous studies had been done to estimate the spatial variation of recharge rates. These five parameters were adjusted during model calibration in order to minimize the difference between simulated and measured values of one or more of the following: (1) estimated base flow in five river basins, (2) water levels in 28 observation wells for which long-term hydrographs were available, and (3) potentiometric surfaces for 1978, 1983, 1988, 1993, and 1998 ground-water-flow conditions.

Water levels in the regional cone of depression centered near the Monmouth and Ocean County boundary in the Wenonah-Mount Laurel aquifer and Englishtown aquifer system have risen about $100 \mathrm{ft}$ from 1988 to 1998 . The rise in water levels in this area is due to a decrease in ground-water withdrawals. Model calibration revealed that storage coefficient is an important parameter in the recovery of water levels in this area. It appears that a large portion of the ground water flowing into this area is going into aquifer storage. Water levels in observation wells screened within the regional cone of depression centered near the Monmouth and Ocean County boundary in the Wenonah-Mount Laurel aquifer and Englishtown aquifer system have been increasing since 1989; therefore, water levels have not reached steady-state conditions with current (1998) ground-water withdrawals.

\section{References Cited}

Barton, Cynthia, and Kozinski, Jane, 1991, Hydrogeology of the region of Greenwich Township, Gloucester County, New Jersey: U.S. Geological Survey Water-Resources Investigations Report 90-4198, 77 p.

Charles, E.G., Storck, D.A., and Clawges, R.M., 2001 Hydrology of the unconfined aquifer system, Maurice River area: Maurice and Cohansey River basins, New Jersey, 1994-95: U.S. Geological Survey Water-Resources Investigations Report 01-4229, 5 sheets.

Harbaugh, A.W., and McDonald, M.G., 1996, User's documentation for MODFLOW-96, an update to the U.S. Geological Survey modular finite-difference ground-water flow model: U.S. Geological Survey Open-File Report 96-485, 56 p.

Johnson, M.L., and Charles, E.G., 1997, Hydrogeology of the unconfined aquifer system, Salem River area: Salem River and Raccoon, Oldmans, Alloway, and Stow Creek Basins, New Jersey, 1993-94: U.S. Geological Survey WaterResources Investigations Report 96-5195, 5 sheets.

Johnson, M.L., and Watt, M.K., 1996, Hydrogeology of the unconfined aquifer system, Mullica River Basin, New Jersey, 1991-92: U.S. Geological Survey Water-Resources Investigations Report 94-4234, 6 sheets.

Lacombe, P.J., and Rosman, Robert, 1995, Hydrology of the unconfined aquifer system in the upper Maurice River basin and adjacent areas in Gloucester County, New Jersey, 198687: U.S. Geological Survey Water-Resources Investigations Report 92-4128, 5 sheets.

Lacombe, P.J., and Rosman, Robert, 2001, Water levels in, extent of freshwater in, and water withdrawals from ten confined aquifers, New Jersey and Delaware Coastal Plain, 1998: U.S. Geological Survey Water-Resources Investigations Report 00-4143, 10 sheets.

Leahy, P.P., 1982, A three-dimensional ground-water-flow model modified to reduce computer-memory requirements and better simulate confining-bed and aquifer pinch outs: U.S. Geological Survey Water-Resources Investigations Report 82-4023, 59 p.

Leahy, P.P., and Martin, Mary, 1993, Geohydrology and simulation of ground-water flow in the Northern Atlantic Coastal Plain aquifer system: U.S. Geological Survey Professional Paper 1404-K, 81 p.

Lewis, J.C., Hochreiter, J.J., Barton, G.J., and Kozinski, Jane, 1991, Hydrogeology of, and ground-water quality in, the Potomac-Raritan-Magothy aquifer system in the Logan Township region, Gloucester and Salem Counties, New Jersey: U.S. Geological Survey Water-Resources Investigations Report 90-4142, 92 p.

Martin, Mary, 1998, Ground-water flow in the New Jersey Coastal Plain: U.S. Geological Survey Professional Paper 1404-H, 146 p. 
McDonald, M.G., and Harbaugh, A.W., 1988, A modular threedimensional finite-difference ground-water flow model: U.S. Geological Survey Techniques of Water-Resources Investigations, book 6, chap. A1, 586 p.

Meisler, Harold, 1980, Preliminary delineation of salty ground water in the northern Atlantic Coastal Plain of New Jersey: U.S. Geological Survey Open-File Report 81-71, 37 p.

Modica, Edward, 1996, Simulated effects of alternative withdrawal strategies on ground-water flow patterns, New Jersey Pinelands: U.S. Geological Survey Water-Resources Investigations Report 95-4133, 46 p.

Nicholson, R.S., and Watt, M.K., 1997, Simulation of groundwater flow in the unconfined aquifer system of the Toms River, Metedconk River, and Kettle Creek Basins, New Jersey: U.S. Geological Survey Water-Resources Investigations Report 97-4066, 100 p.

Pope, D. A., and Gordon, A. D., 1999, Simulation of groundwater flow and movement of the freshwater-saltwater interface in the New Jersey Coastal Plain: U.S. Geological Survey Water-Resources Investigations Report 98-4216, 159 p.

Seaber, P.R., 1965, Variations in chemical character of water in the Englishtown Formation, New Jersey: U.S. Geological Survey Professional Paper 498-B, 35 p.

Sloto, R.A., and Crouse, M.Y., 1996, HYSEP: A computer program for streamflow-hydrograph separation and analysis: U.S. Geological Survey Water-Resources Investigations Report 96-4040, 46 p.

Spitz, F.J., 1998, Analysis of ground-water flow and saltwater encroachment in the shallow aquifer system of Cape May County, New Jersey: U.S. Geological Survey Water-Supply Paper 2490, $51 \mathrm{p}$.

Trescott, P.C., 1975, Documentation of finite-difference model for simulation of three-dimensional ground-water flow: U.S. Geological Survey Open-File Report 75-438, 103 p.

Walker, R.L., 1983, Evaluation of water levels in major aquifers of the New Jersey Coastal Plain, 1978: U.S. Geological Survey Water-Resources Investigations Report 82-4077, $56 \mathrm{p}$.

Watt, M.K., 2000, A hydrologic primer for New Jersey watershed management: U.S. Geological Survey Water-Resources Investigations Report 00-4140, 108 p.

Watt, M.K., and Johnson, M.L., 1992, Water resources of the unconfined aquifer system of the Great Egg Harbor River basin, New Jersey, 1989-90: U.S. Geological Survey WaterResources Investigations Report 91-4126, 5 pls.

Watt, M.K., Johnson, M.L., and Lacombe, P.J., 1994, Hydrology of the unconfined aquifer system, Toms River, Metedeconk River, and Kettle Creek Basins, New Jersey, 1987-90: U.S. Geological Survey Water-Resources Investigations Report 93-4110, 5 sheets.
Watt, M.K., Kane, A.C., Charles, E.G., and Storck, D.A., 2003, Hydrology of the unconfined aquifer system, Rancocas Creek area: Rancocas, Crosswicks, Assunpink, Blacks, and Crafts Creek Basins, New Jersey, 1996: U.S. Geological Survey Water-Resources Investigations Report 02-4280, 5 sheets.

Zapecza, O.S., 1989, Hydrogeologic framework of the New Jersey Coastal Plain: U.S. Geological Survey Professional Paper 1404-B, 49 p., 24 pl. 


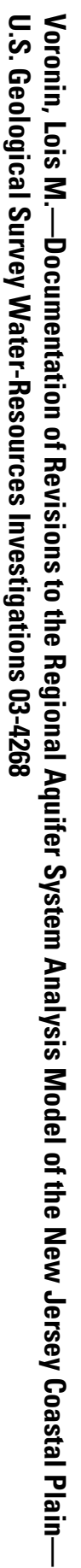

Printed on recycled paper 
COLUMN NUMBER OF REVISED MODEL

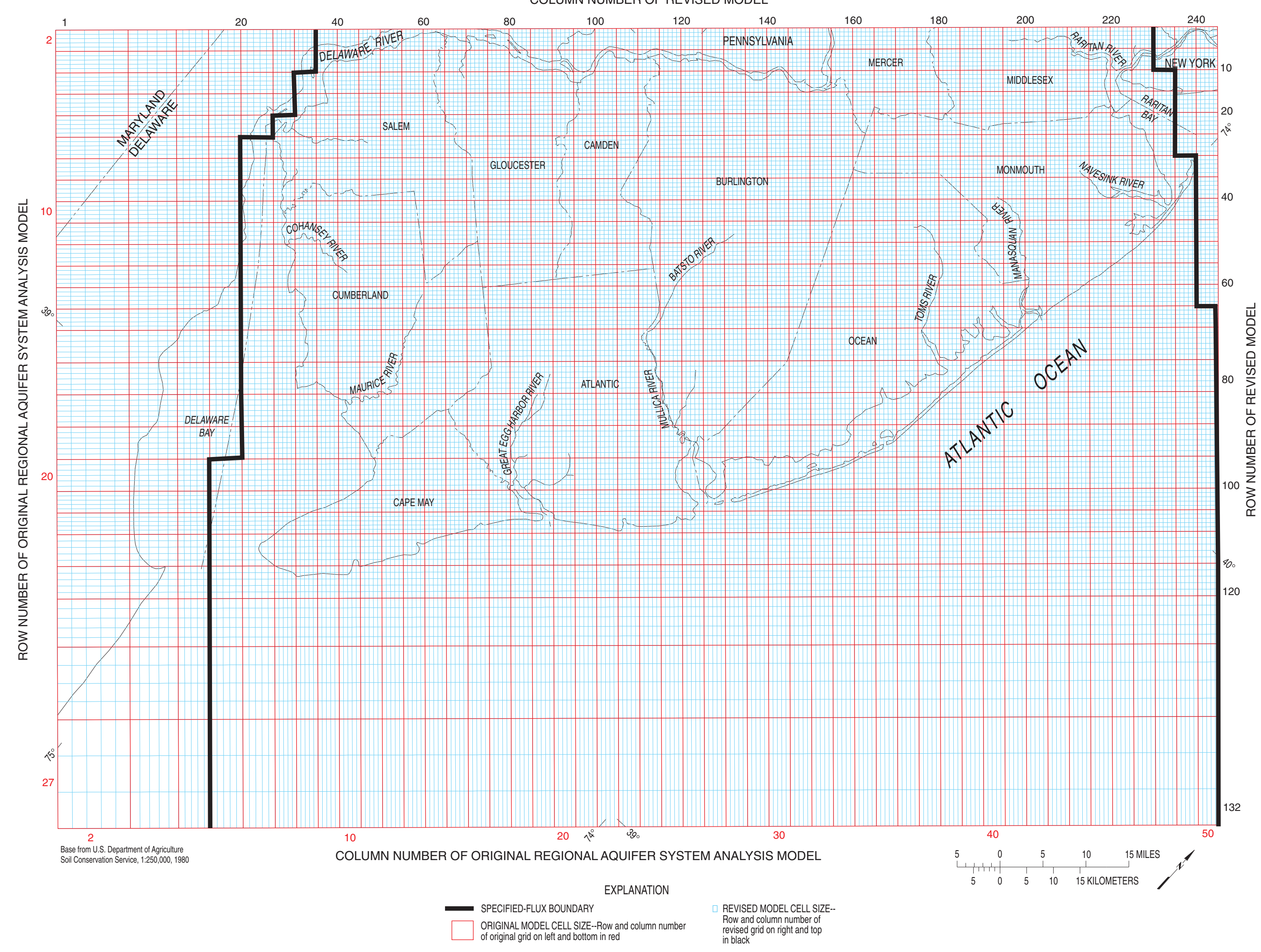

FINITE-DIFFERENCE GRID AND GENERALIZED LATERAL BOUNDARIES OF THE ORIGINAL AND REVISED REGIONAL AQUIFER SYSTEM ANALYSIS MODELS OF THE NEW JERSEY COASTAL PLAIN

$$
\begin{aligned}
& \text { By } \\
& \text { Lois M. Voronin } \\
& \text { 2004 }
\end{aligned}
$$

